SAAY'E CE AJMSKA

WS. I ian A. Egras - Governor

JEPAKTMENR OS WA'CUINAL RESOURCES

Pbil R. Holdsworth - Commisgioner

DIVIEYON OF MINES AND MINERALS

James A. Wi.Liams - Director

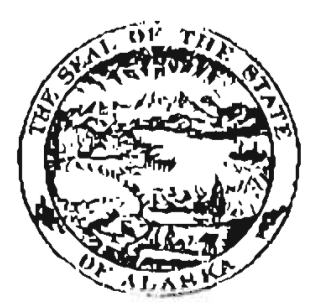

GEOCHEMICAL REPORT NO. 7

Geochemical Investigations Along Highway and

Secondary Roads in Southcentral Alaska, 1965

By

M.W. Jasper

Juneau, Alaska

June 1966 
Page

Summatey

Inturaxinet ion

ropegraghy

Generad Geology 2

Minderal Deposits 2

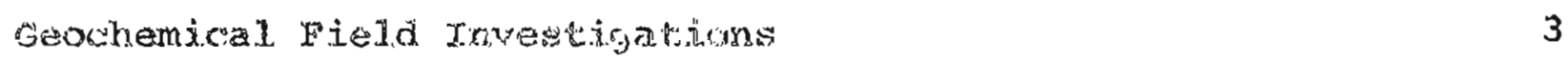

Results

$\begin{array}{ll}\text { ketexences } & 8\end{array}$

\section{IHLUSTRATIONS AND TABLES}

Diagram showing locations of Exgures 1 to $19 \quad 9$

Figures 1 to 19. Samole location maps 10

Concentration Erequency graph for copper, lead, zinc, mólybdenum, and nickel for Figure 1

concentration Erequency graph for copper and lead for Figures 2 to 19

Concentration frequency graph tor zinc, molyodenum, and nickel. for Eigures 2 to 19

Wables 1 to 19. Resul ts of analyses 


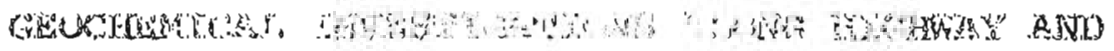

SECONDA

\author{
(2)

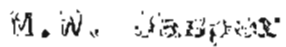

STYMNARYY

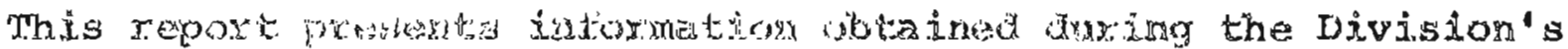

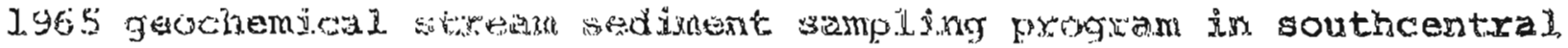

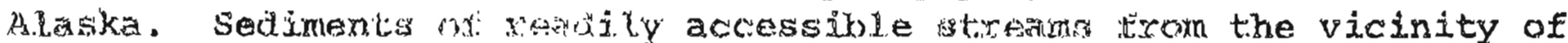

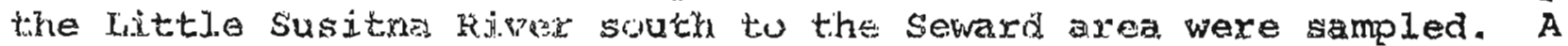

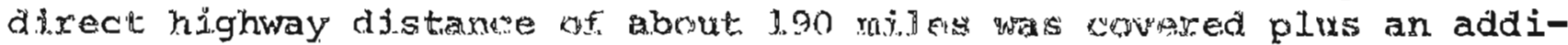

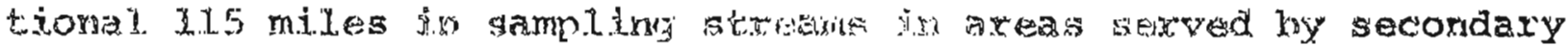
rovids.

Two hundred and eight samples were solidedted and analyzed for copper, lead, wine, molybdenum, snd wickel. Mypes of bedrock. "float" in stream beds, general geology of the vicinity, and mention of any known ox observed mineral occurxences were recorded at each sample site. A sample was panned at each site to stpllest any heavy minerals

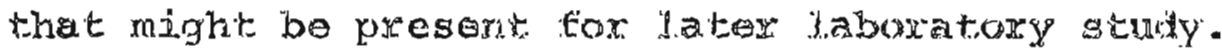

Of: the 208 smanples collected and axylyod duxing this investigation, three were tound to be strongl.y andinalons (ribokel and lead) and 32 were moderately anomalous.

\title{
INTRODUCSTON
}

The geochemirai strean sedixcent sampling program of the Division

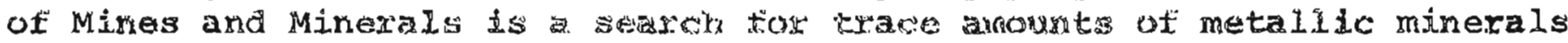
fcopper. Iead, whice molyzoderum, and nicked) which may lead to the location of hidden ore depusits. It is primatily for benefit of prospectors and others excaged in mineral expluention in an effort to bring new mineral. production to the state.

Of the 208 samples covers ind this repoxt. 148 were taken by the authox, and 60 by Axthux Rose, Division goologist, ard his assistant, David Bary. During the pexiod Rose was mappisig in the area between Knik River bridge and Eagle River, 17 stream sedintent samples taken by them were added to those taken by the author in the same general area (figure 3 to 6 ). Forty-three samples taken by Hay in the Hope area and at selected polnts from the Hope xoad junction south to the Slate creek are also included (figures 11, 12, 13, 25, and 16). 


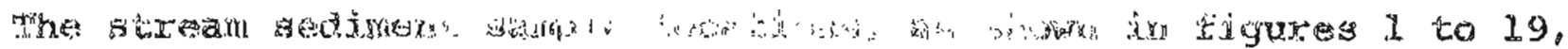

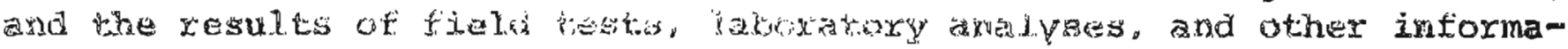

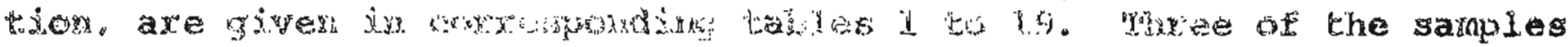

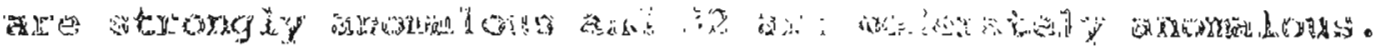

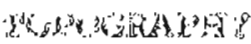

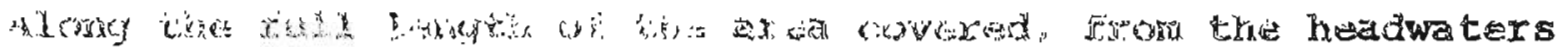

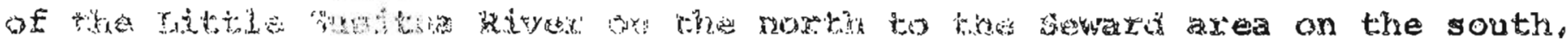

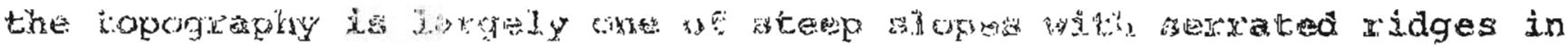

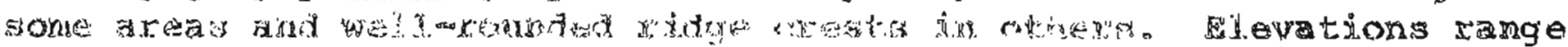

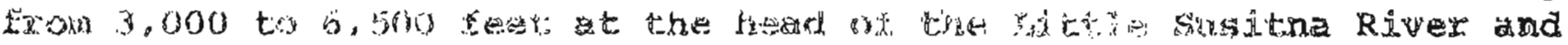

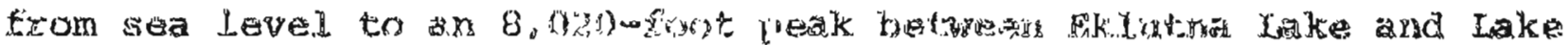

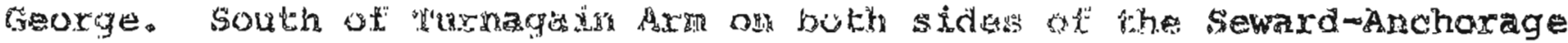

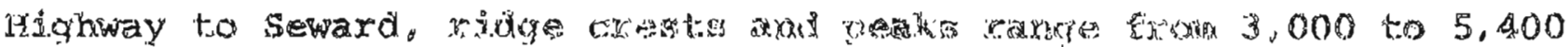
Leet.

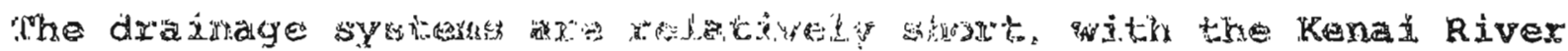

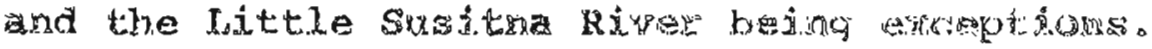

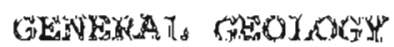

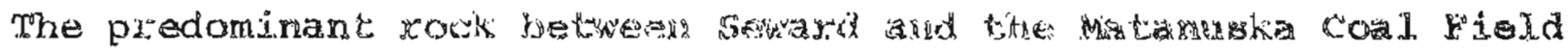
is a great trickness of metssedinexts. Jat portion of the strean

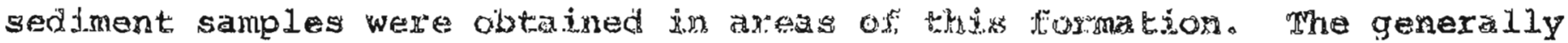

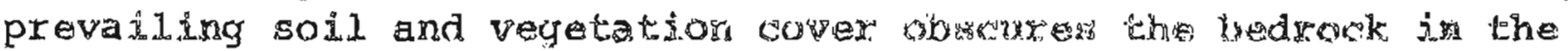
vicinity of many of the anple sitso.

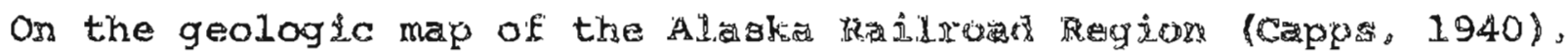

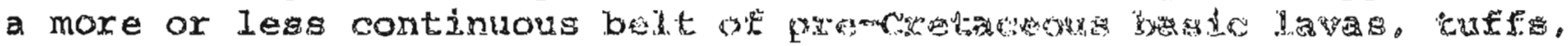

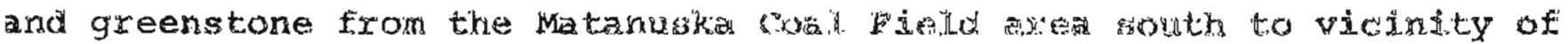
Seward is shown. Between wolver trusives have invaded the basic d

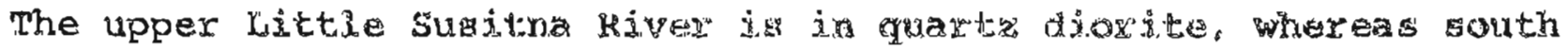
If the lodge it is entxenched in arkos sud songlomerate.

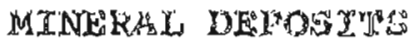

since the first influx of prospectoris into the sewaxd to willow seek region around 1900, the primary intexes. has beer the search jor gold-quartz and placer gold deposite or the ming lode discoveries lade in the seward to Hope arean, none have prover to be of real tmportance :o date. 


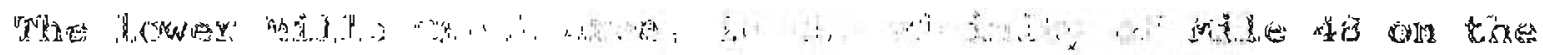

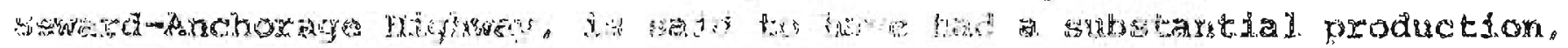

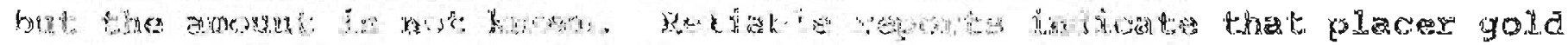

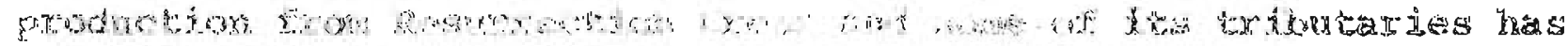

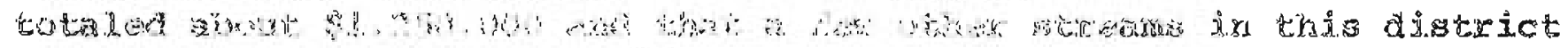

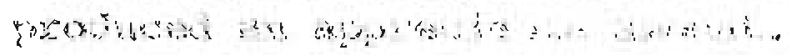

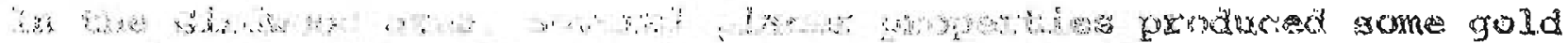

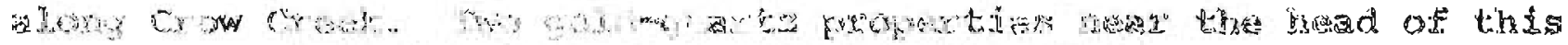

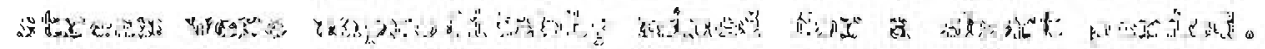

कy

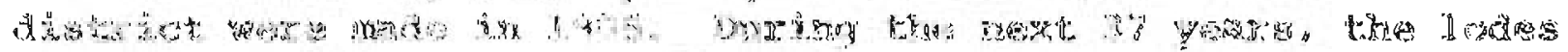
a 3 s.

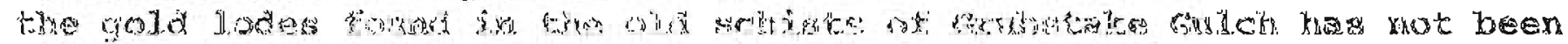

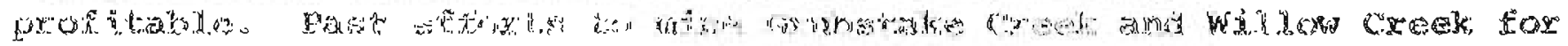
L L

4.

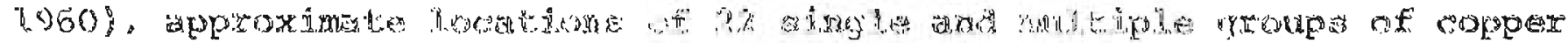

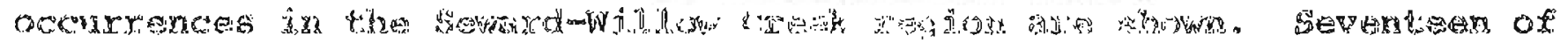

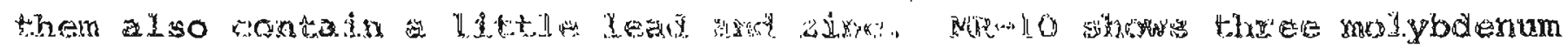

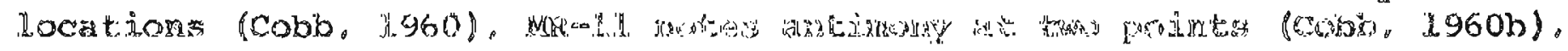

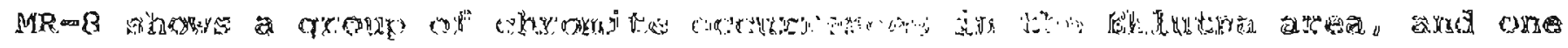

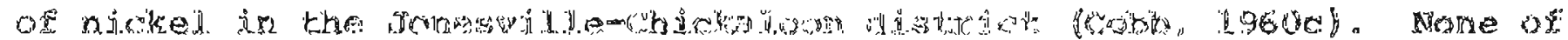

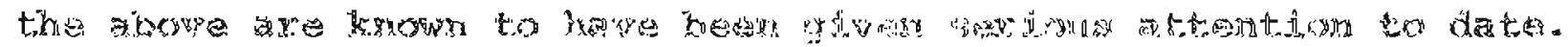

\section{CHOH}

As previonsiy noted。 50 semples

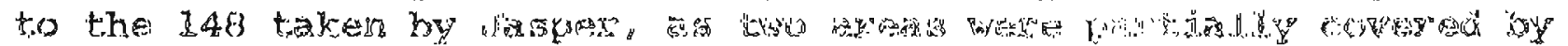

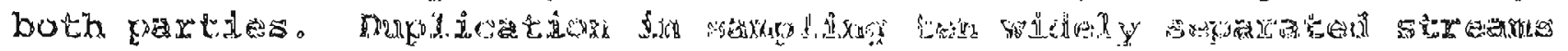

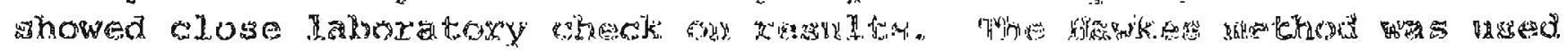

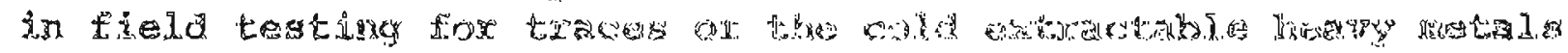
(Hatwikga, 1.963).

Sample

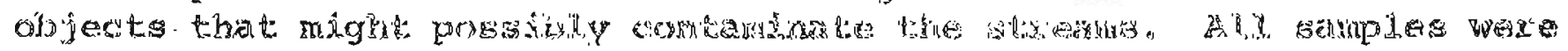

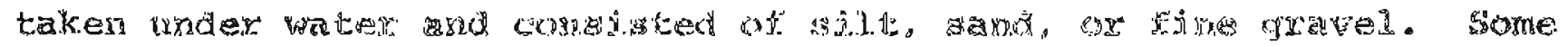

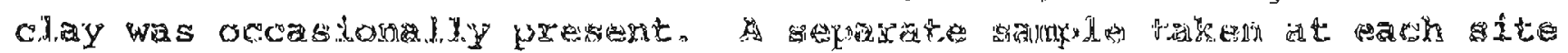

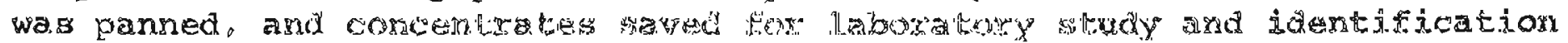

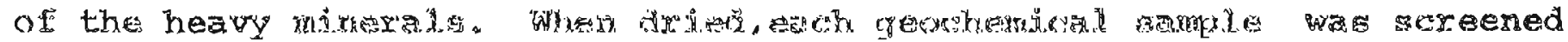

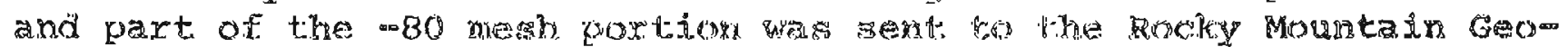

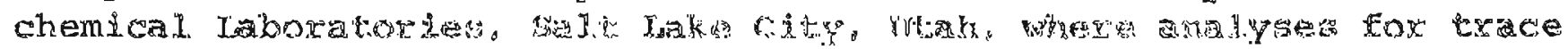

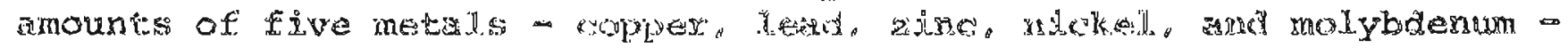
werte made. 


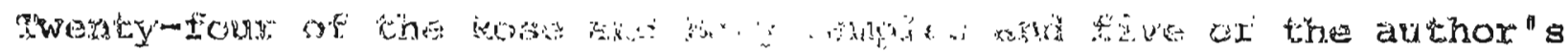

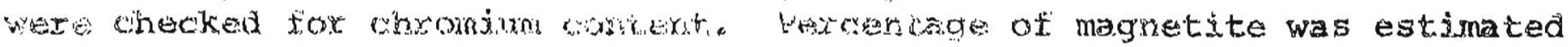

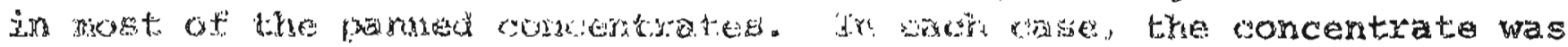

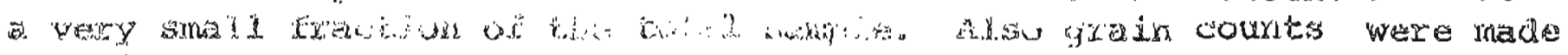

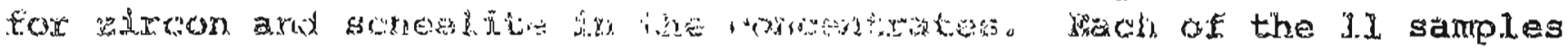

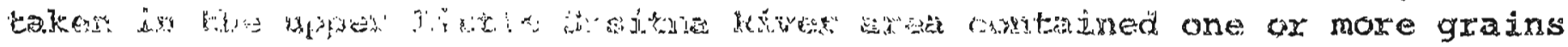
o.

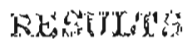

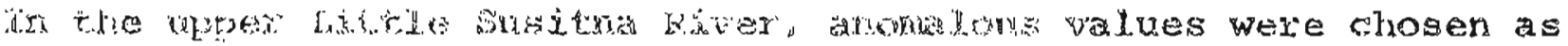

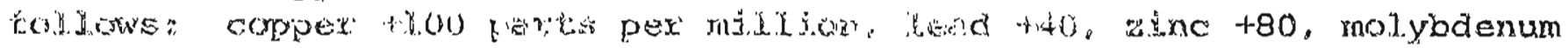
+5. ard nociked +100.

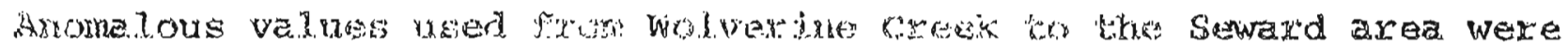

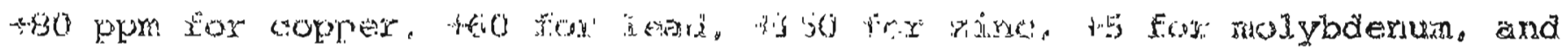
+10 li for rilickel.

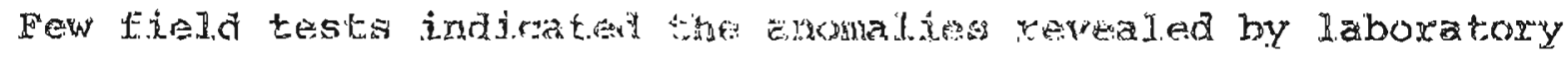

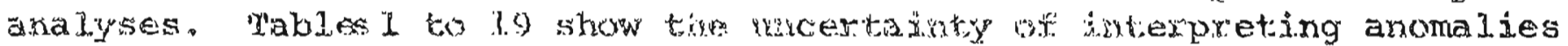
from field testas, whinh suggesto that exh simple should be analyzed

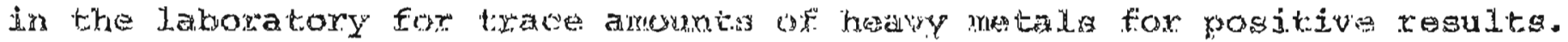

Tat.t.

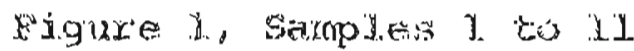

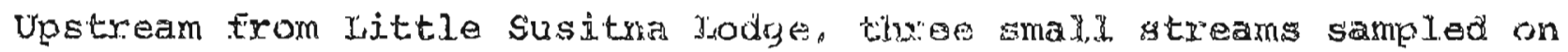
the north side of the river were noderately anomalous with an average of 85 ppm zinc, and 110 pom copper 12964 sampl.e Locations, prefixed by "C" are shown on figure 1, as these 15 samples werte included in establishjng

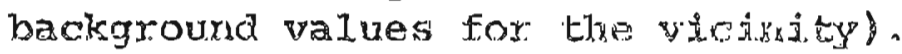

\section{Wolverine creek to Niwkell wreste

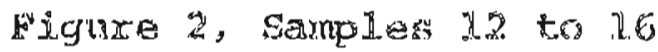

In this area three or the fise samples wexe moderately anomalous. Sample at No. 12 had knomalows nidkell (120 ppm), No. "25. molybderum

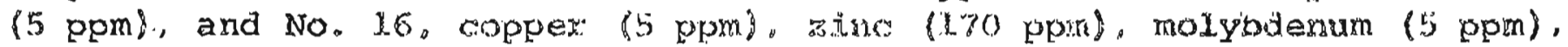
and nickel (115 pum).

The three short streams, between samplew No. 15 and 16 , were dry when vistied and therefore not sampled. As lacad residents report that some copper has been found near the heads of these seasonal streams and that some work has been done on the prospects in the past, the upper reaches of the three creeks should be sampleral. 


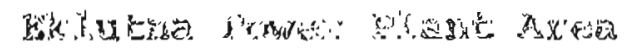

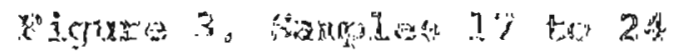

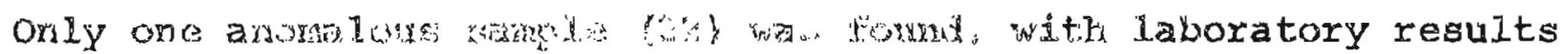

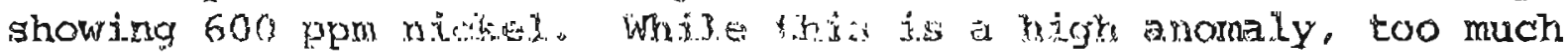

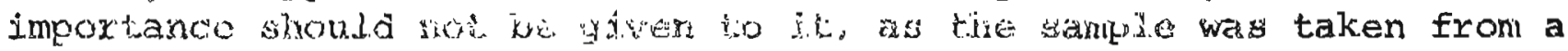

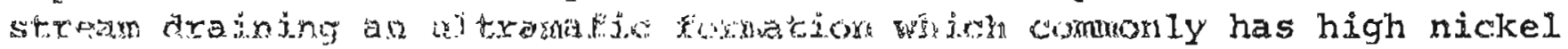
backigerund.

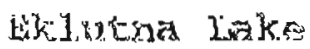

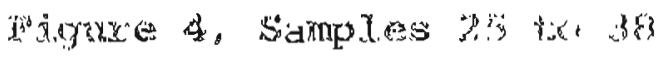

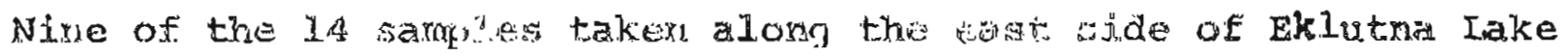

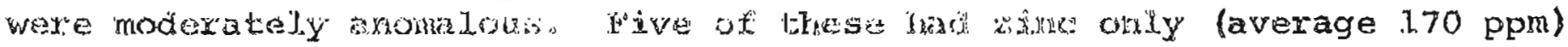
two of molybdenury (7 ppm) oxly, one of ron pan mikkel, Samples 27. 30,

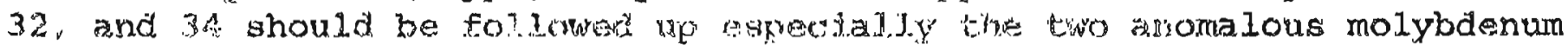
samples.

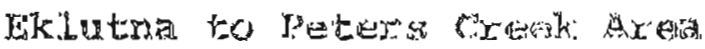 Figure s. Siamples. 39 to 50}

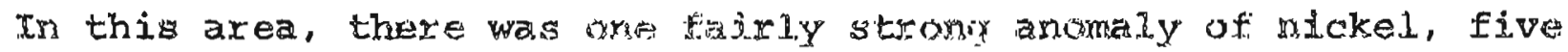
moderately anomalous nickel. and one of uxirs they are probably due to

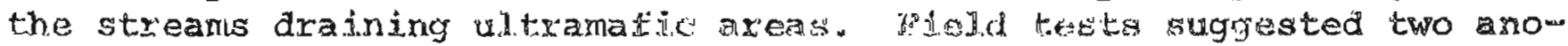
malous samplea which were hot comblrmed in the laboratory analyses.

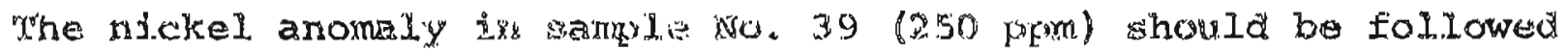
up with additional samplinse.

\section{Petors Cyek to Eagle Rivar Area \\ Figures 6, Serripdes 51 to 92}

of the 22 samples raken in this area ymly sample No. 51 was

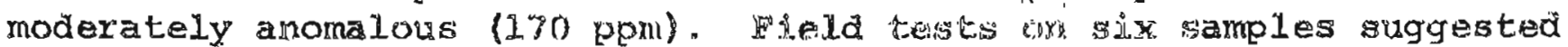
momalies which the laboratory aralyses did not ronfin. The moderately anomalous zinc sample No. 51 , js of sufticlent interest to fol. low up with additional sampling.

\section{Little Rabbit creek to kajubow \\ Eigure 7, samples 73 tor 7 te}

None of the four samples obtained in this are were anomalous. However, older residents of the area report scattered copper occursences neax the $x$ idge crest of the mountain immediately north of Rainbow that should be checked. 


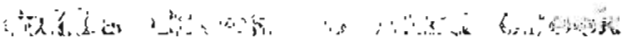

$$
\begin{aligned}
& \text { Digute 8. Santoles "y bo by }
\end{aligned}
$$

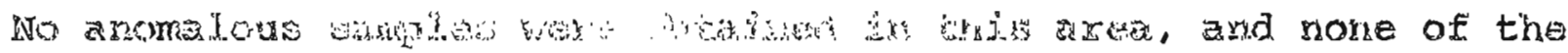

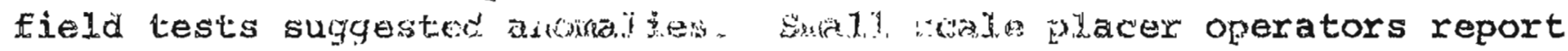

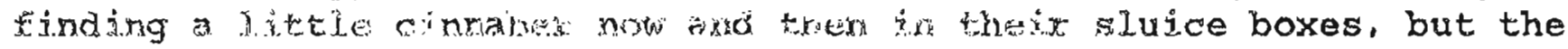

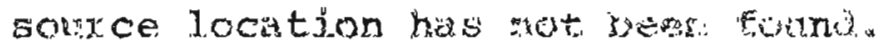

$$
\begin{aligned}
& \text { L }
\end{aligned}
$$

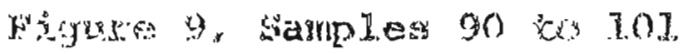

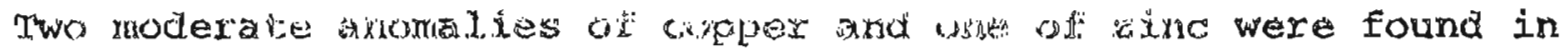

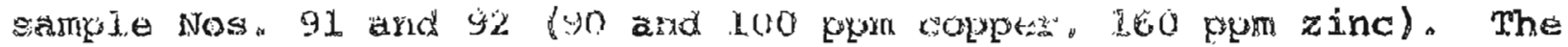

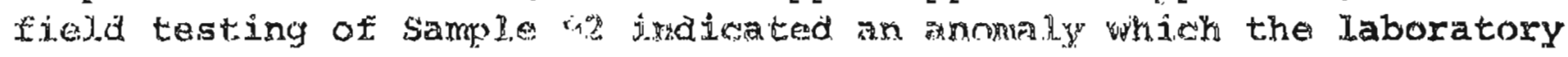
analysis confirmed. Followenp sampling for buth streams is suggested.

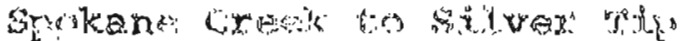

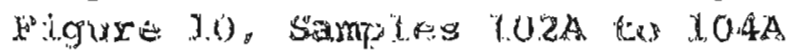

One moderate $z$ inc anomaly 1950 ppm was vituther in this axea. It is not considered of sufticient, intorest to follow up.

$$
\begin{aligned}
& \text { Hope Distriet Area }
\end{aligned}
$$

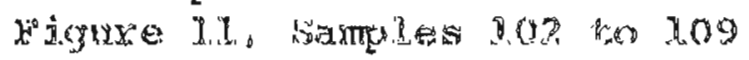

No anomalies wexe indicated by sampilik taken in this area, eithar by fleld or laboratory resiltis.

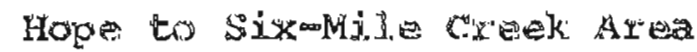

$$
\begin{aligned}
& \text { Elguxe 1.2, Samples } 1.20 \text { to } 1.2 \%
\end{aligned}
$$

Iaboratory analysex of the stream sediment sarming in this area did not find any anomelous sited, nor were ayy indicted in field testing. results.

Six Mile Creek Area

wigure 1.3. Samples 23 to 139

In this area. five of the eighteer sampiles were anomalous, ali of which are Iimited to zinc. The parts pex rallilion range was 170 to 190 ppm. A few follow-up samples are suggesced. foild test results for these five samples did not indicate the anomalies revealed by the laboratory analyses. 


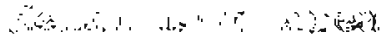

$$
\begin{aligned}
& \text { Fion }
\end{aligned}
$$

Laboratory ats

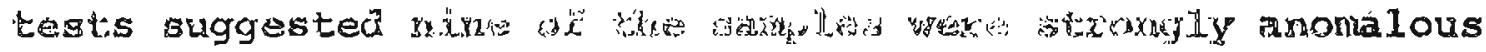

$$
\begin{aligned}
& \text { W. }
\end{aligned}
$$

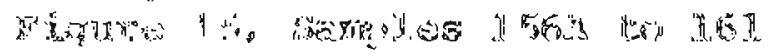

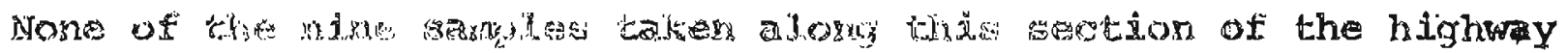
were tongd to be

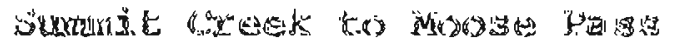

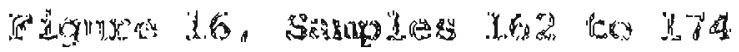

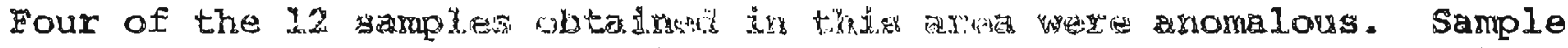

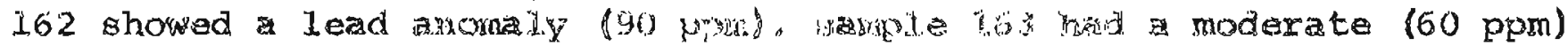

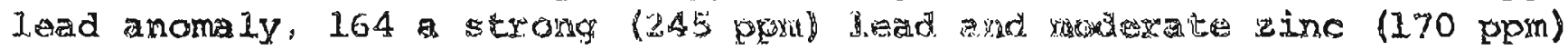
anomaly, and 169 moderately angmallow 162 was the only one indicated in at the slate Creek locatinn should br checker and followed up, as there is possibility it may be payty or largely du to contamination from

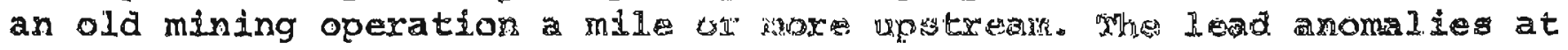

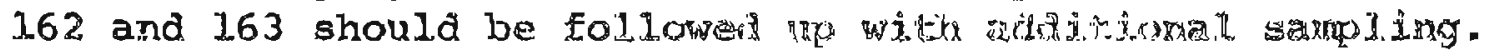

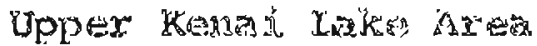

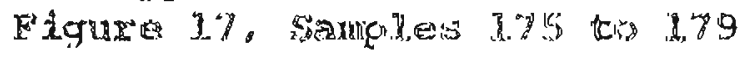

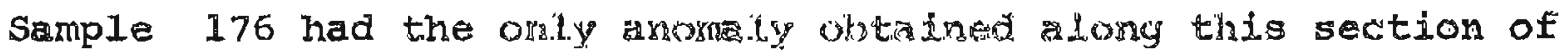
the highway. The three metals, ropper 480 puml. winge (150,pum), and nickel (105 ppm), are slightly amomalown. but: wh the metal content

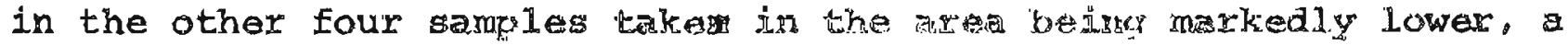

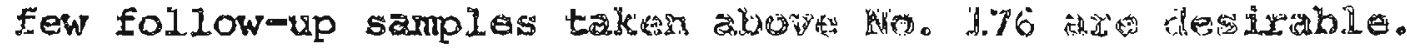

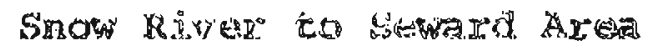 \\ Figure L8, Saropiles 180 to $28 \%$
}

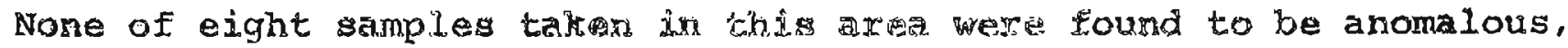

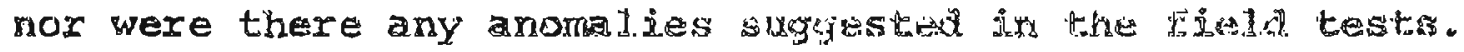

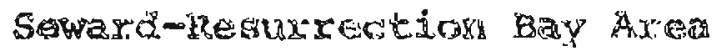

Figure d9, samples 187 to 1.99

Fourteen samples were takere in this axea. libaratory analyses did not detect anomalous metals in any of them. 
Waps, S.A., 1940, Alaska railroad cegion: U.S. Goological Survey Bulletin 907

Cobb, E.H., 1960, Eopper, lead, and zine occurrences in Alaska: U.S. Ceological Survey Mineral Investigations Resource Map MR-9

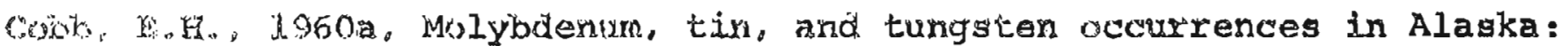
tj. S. Geologiral Survey Mineral Investigations Resource Map MR-10

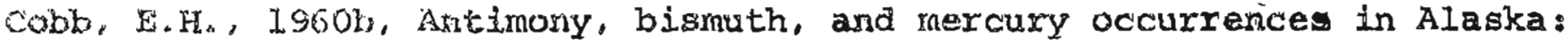
U.S. Geologi.cal. Survey Mineral Investigations Resource Map MR-II

Cobb. E.H.. 1960c, chromite, cobalt, nickel, and platinum occurrerices in Alask : V.S. Geological Survey Mnexal Investigations Resource Map Wat -8

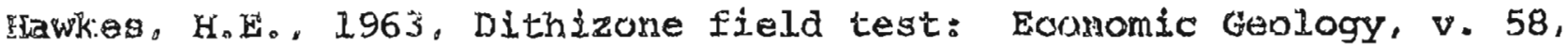
p. $579-586$ 


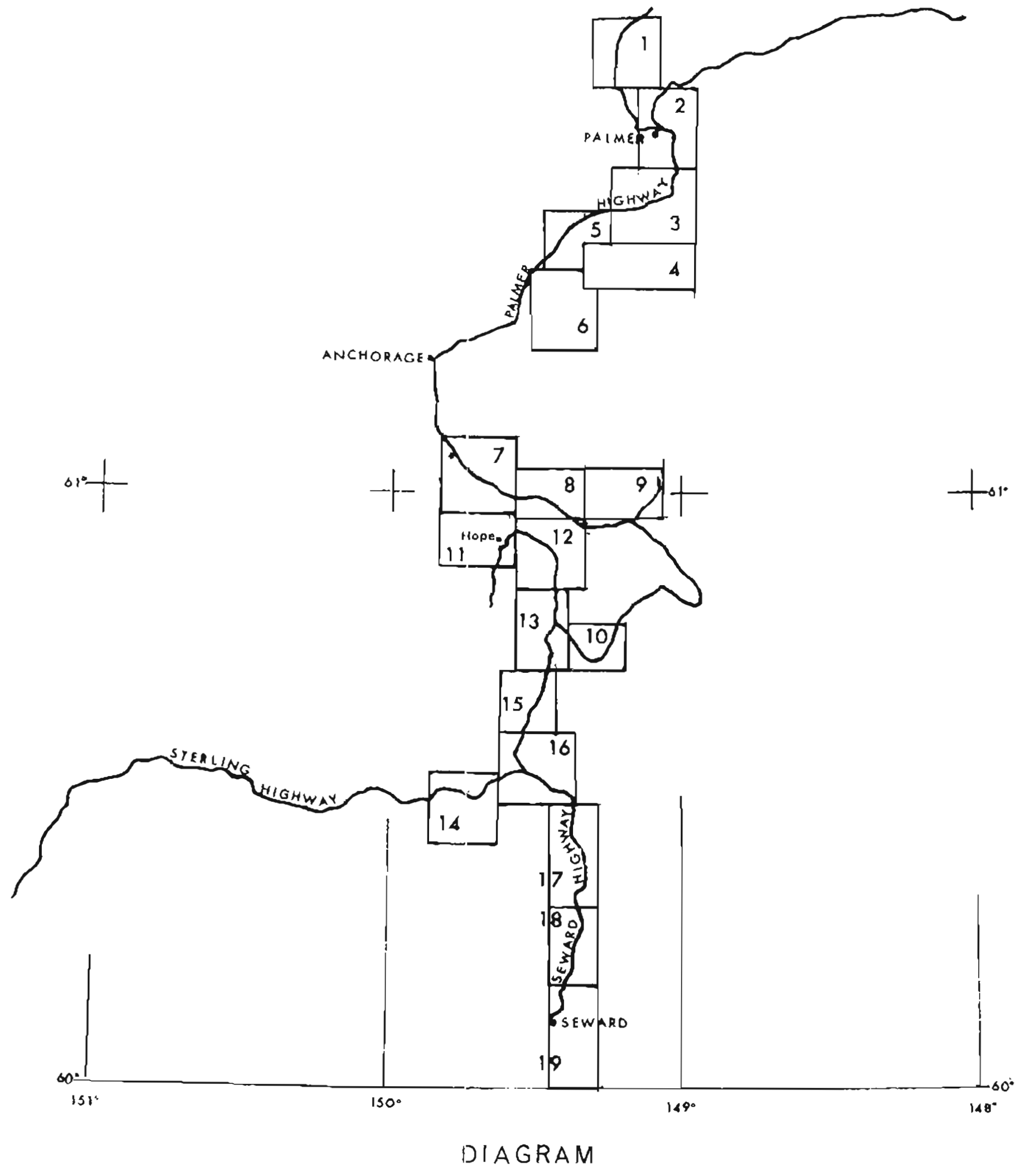

Showing Locations of

Fig.s 1 to 19 


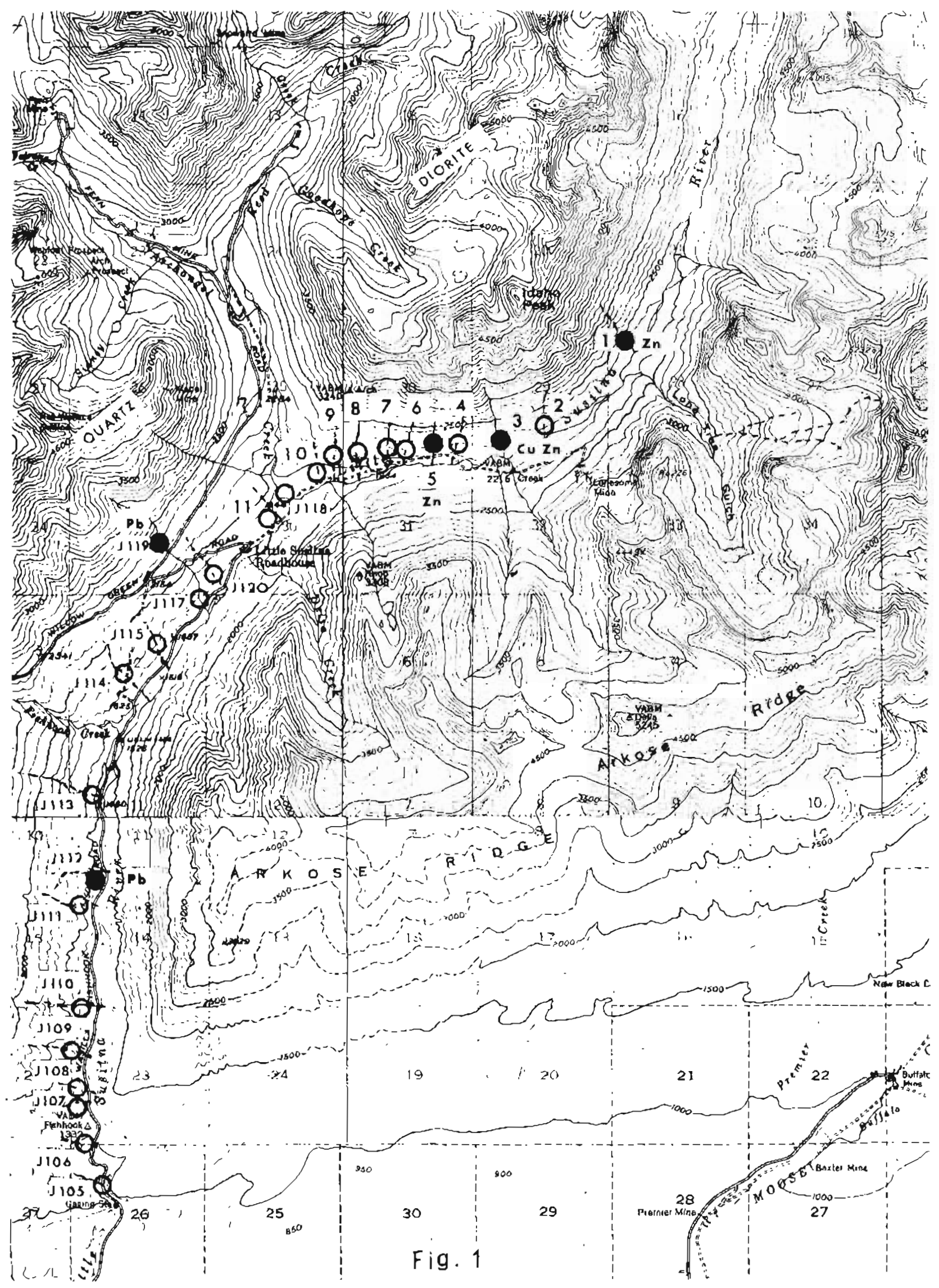




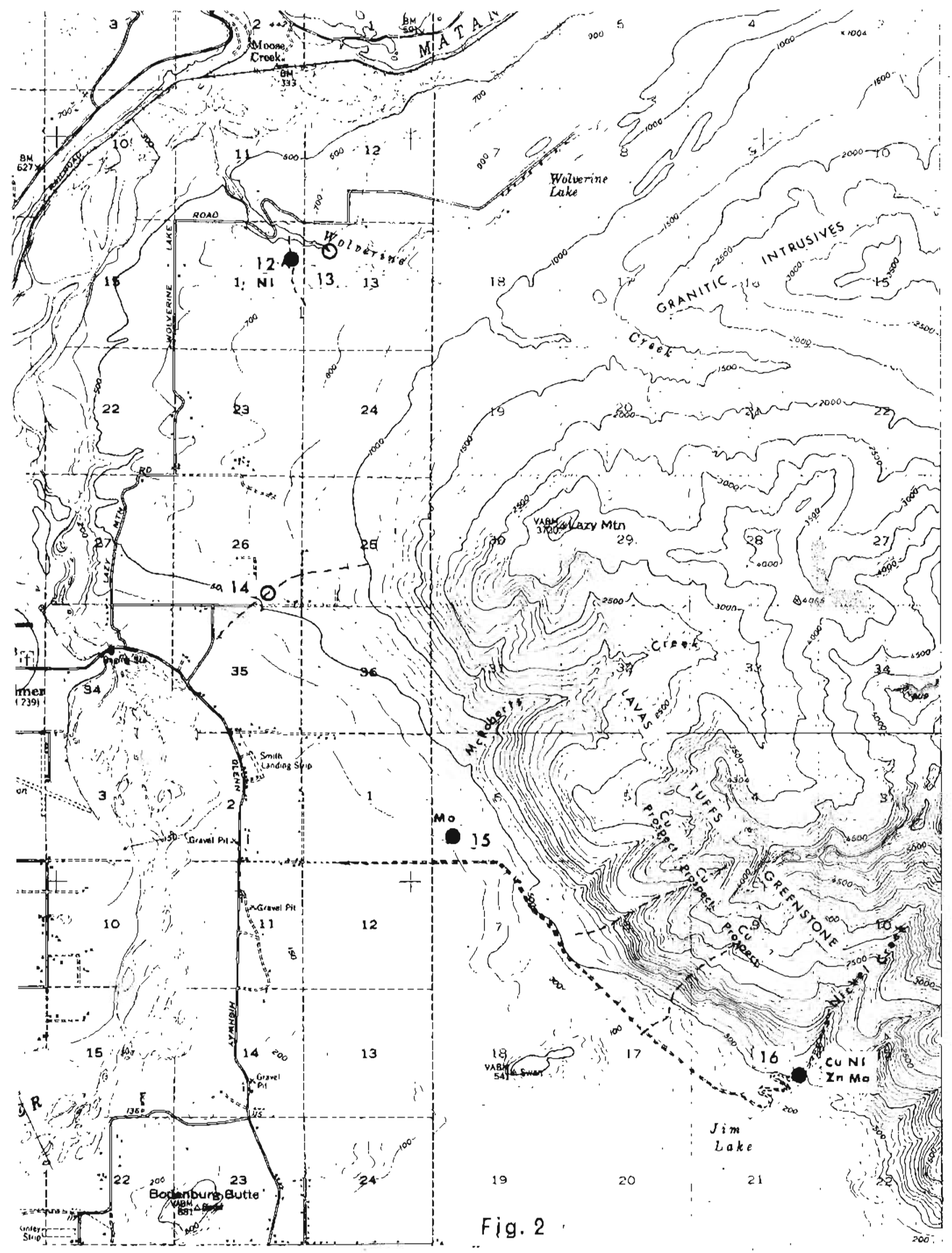




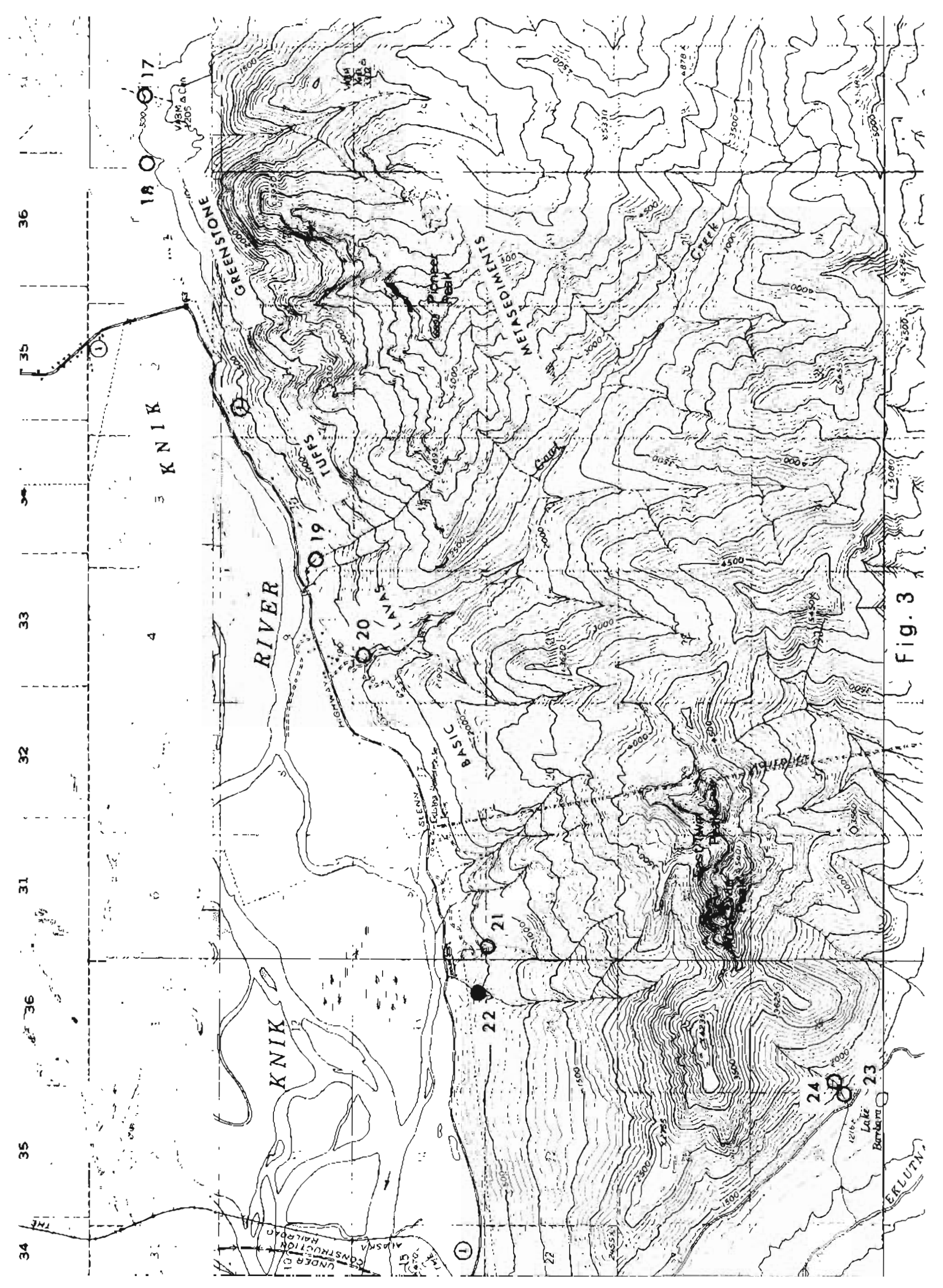




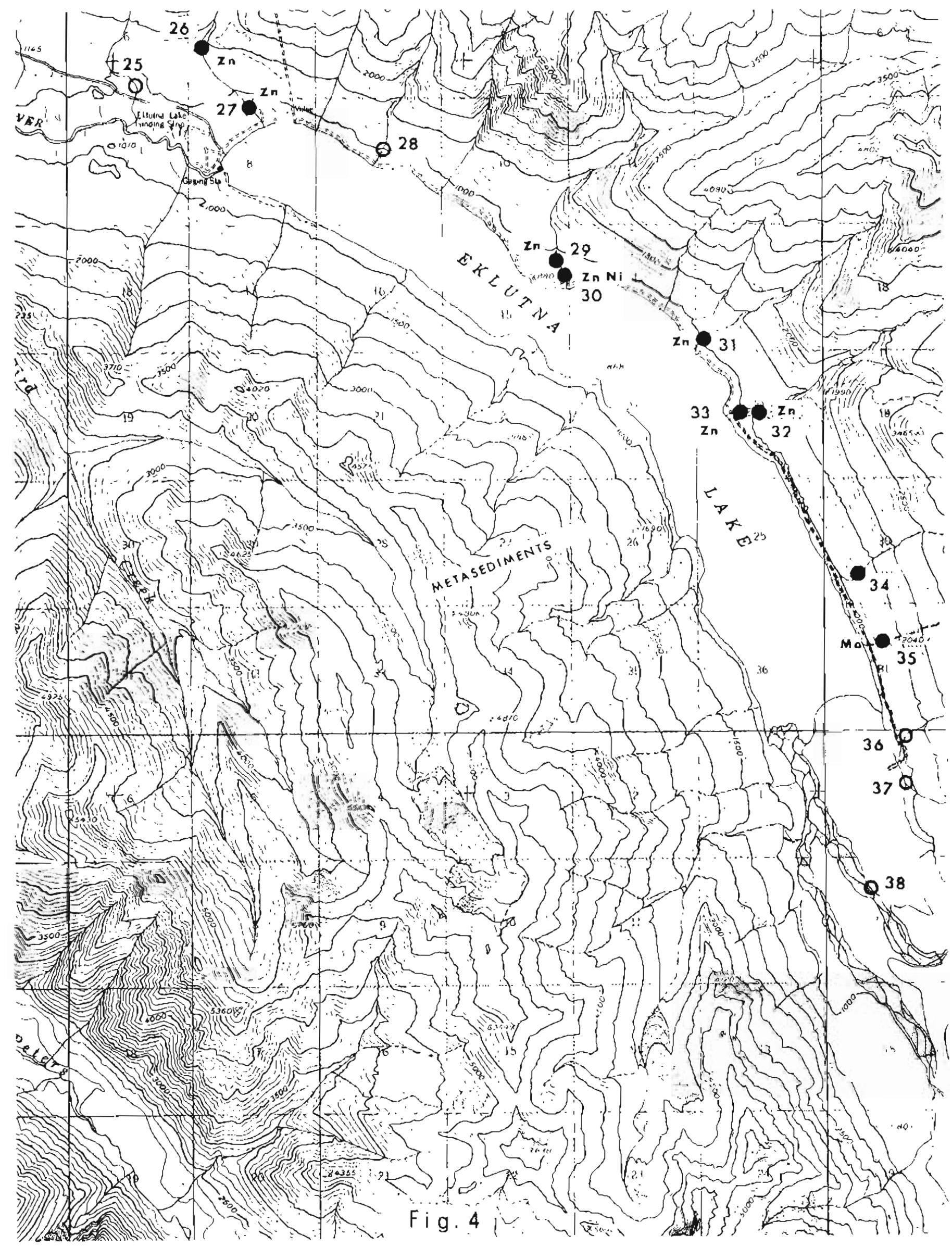




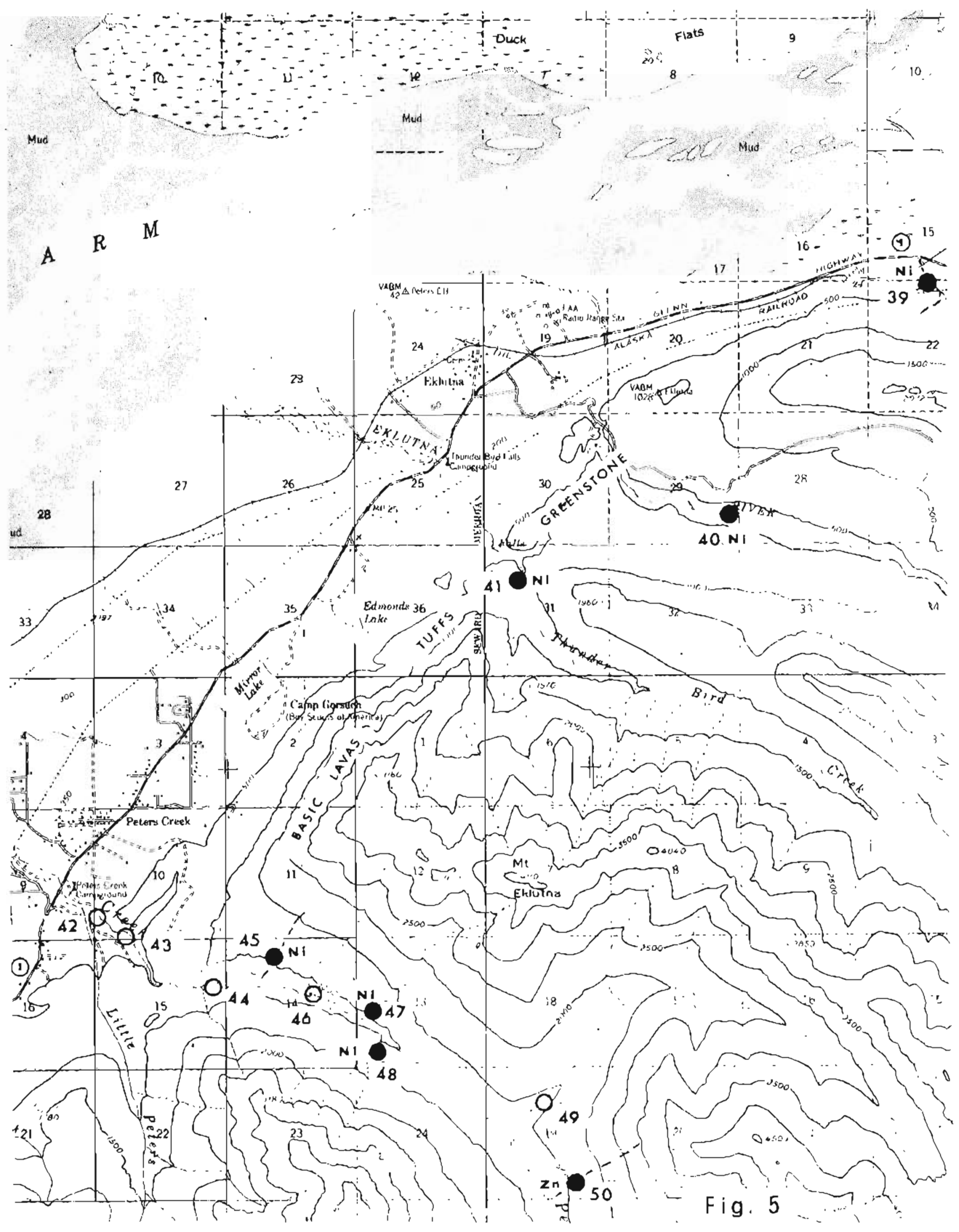




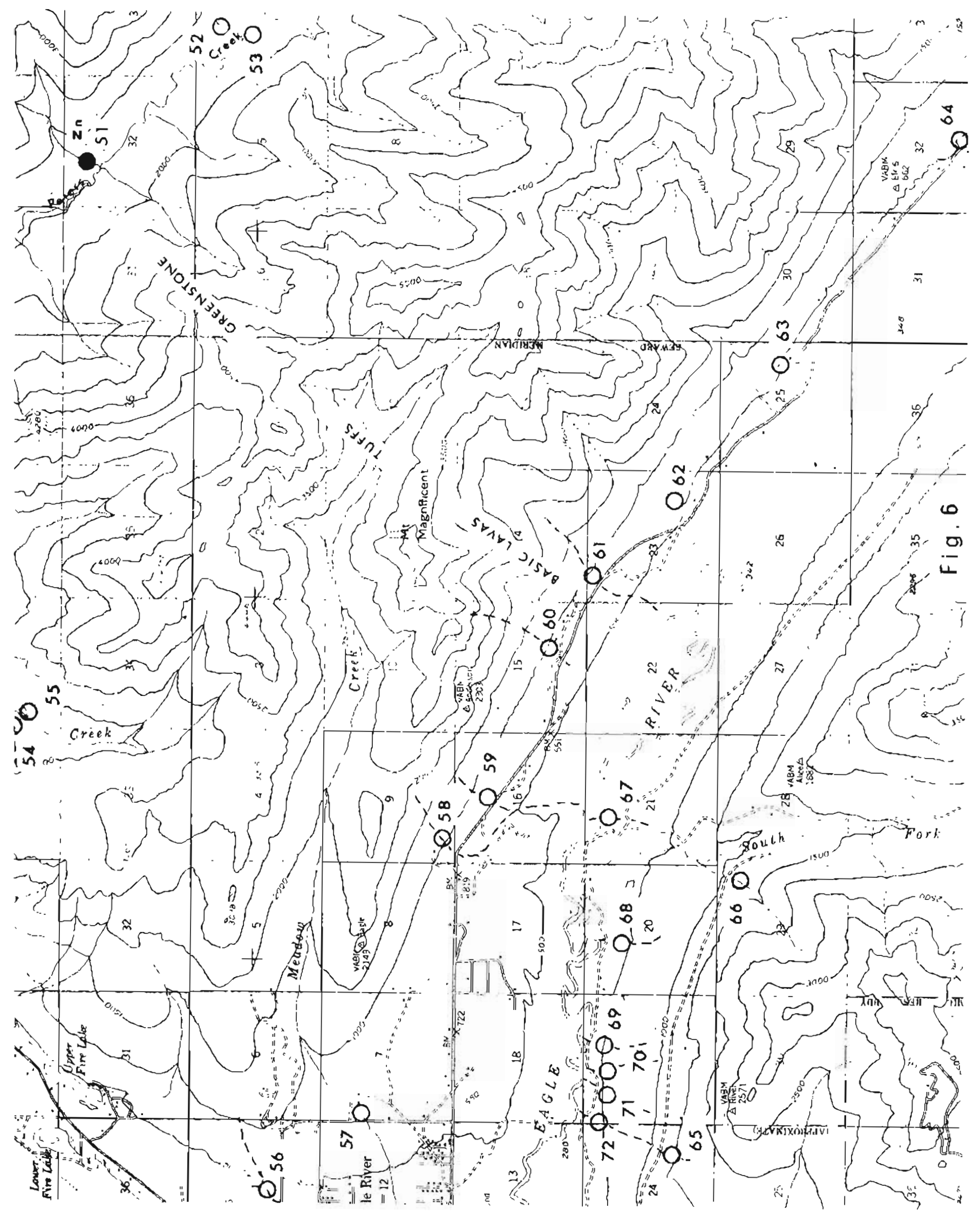




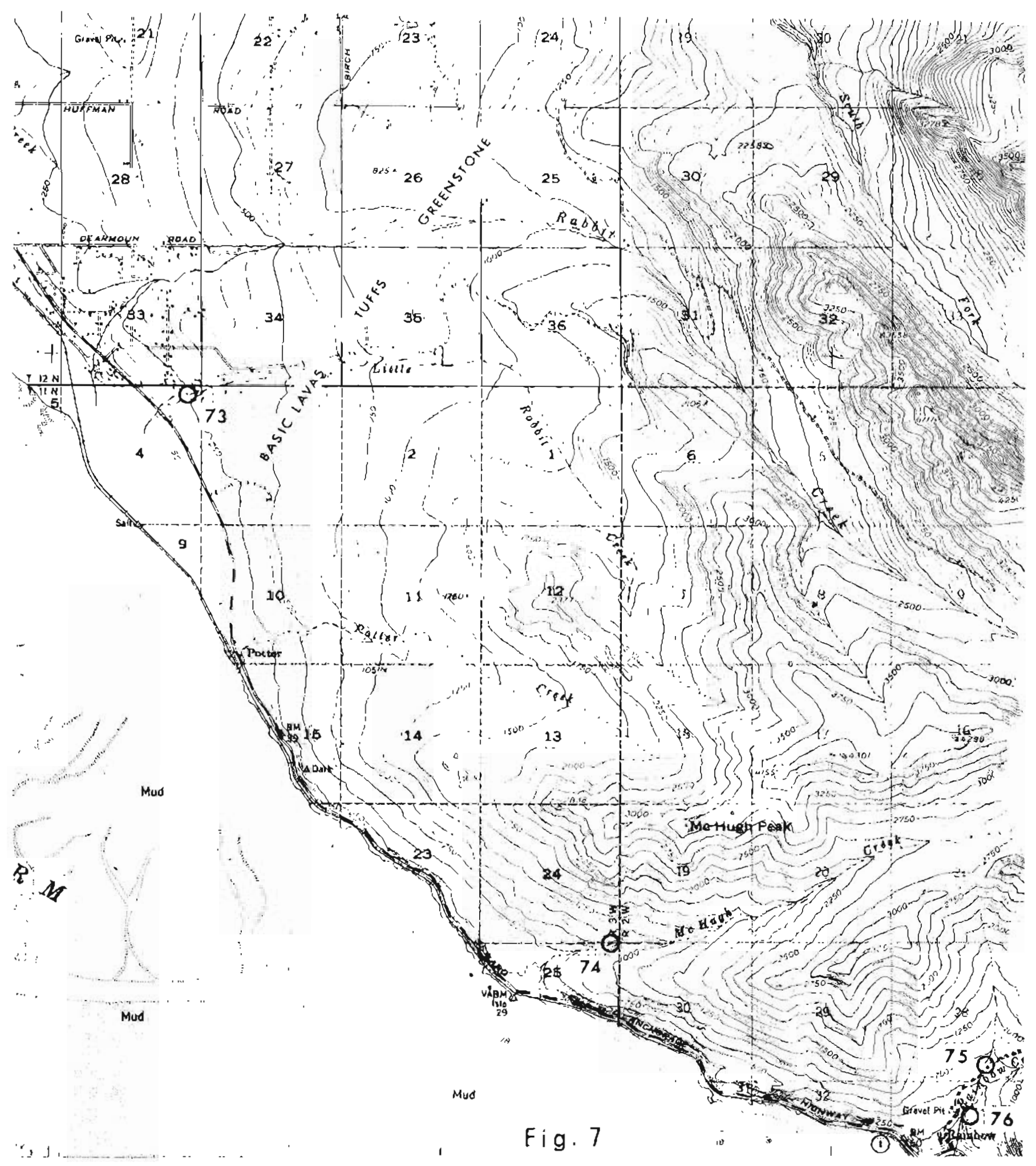




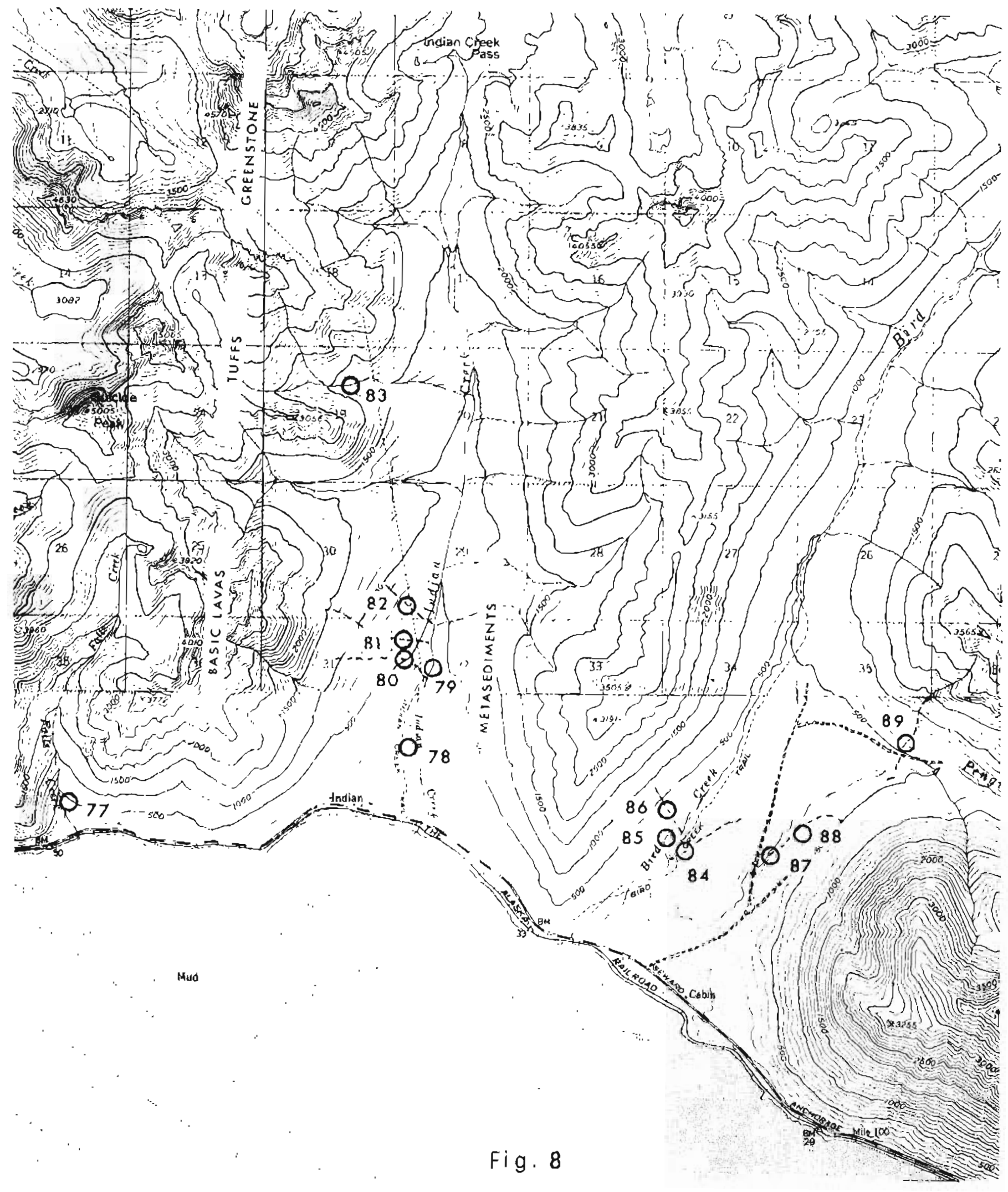




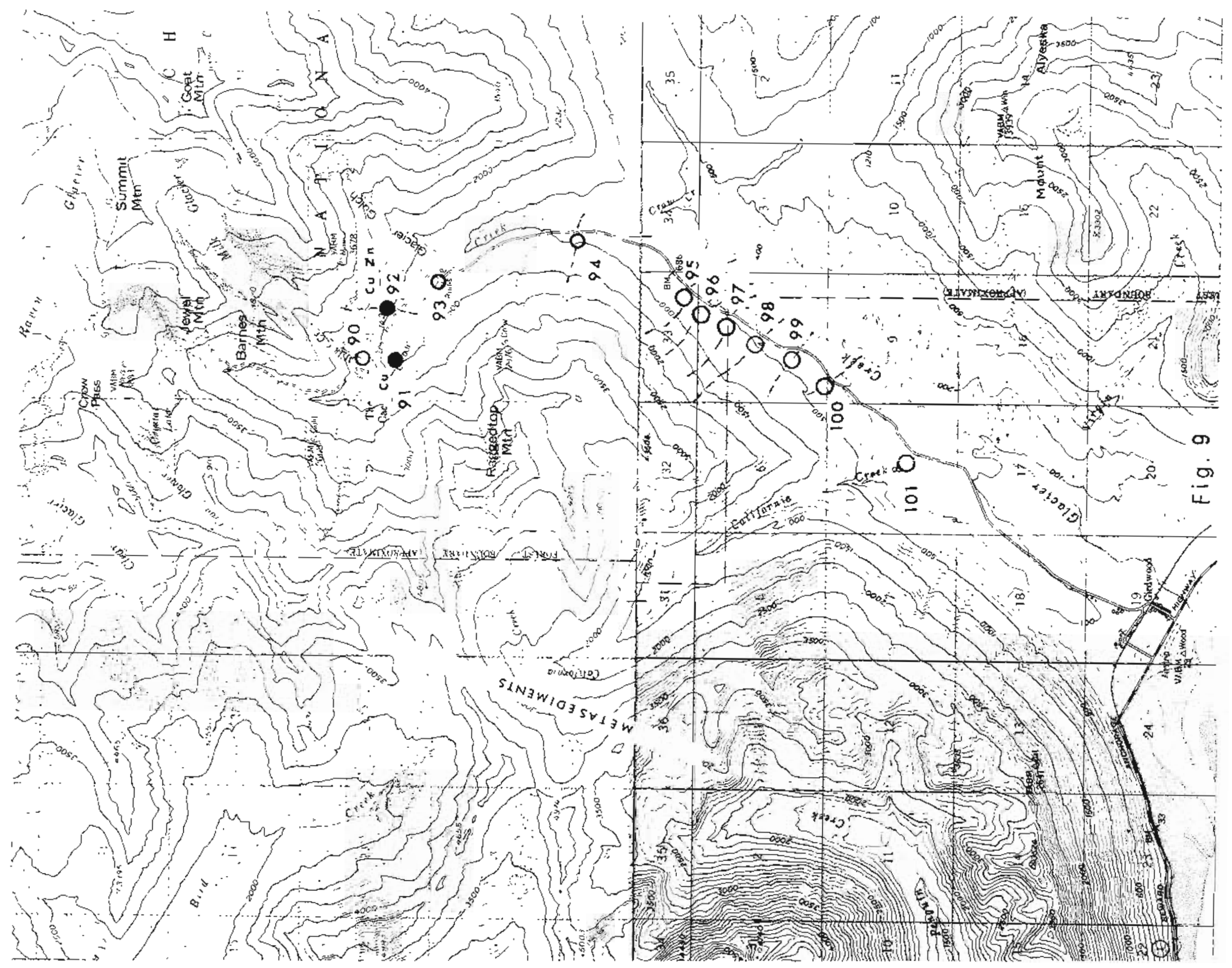




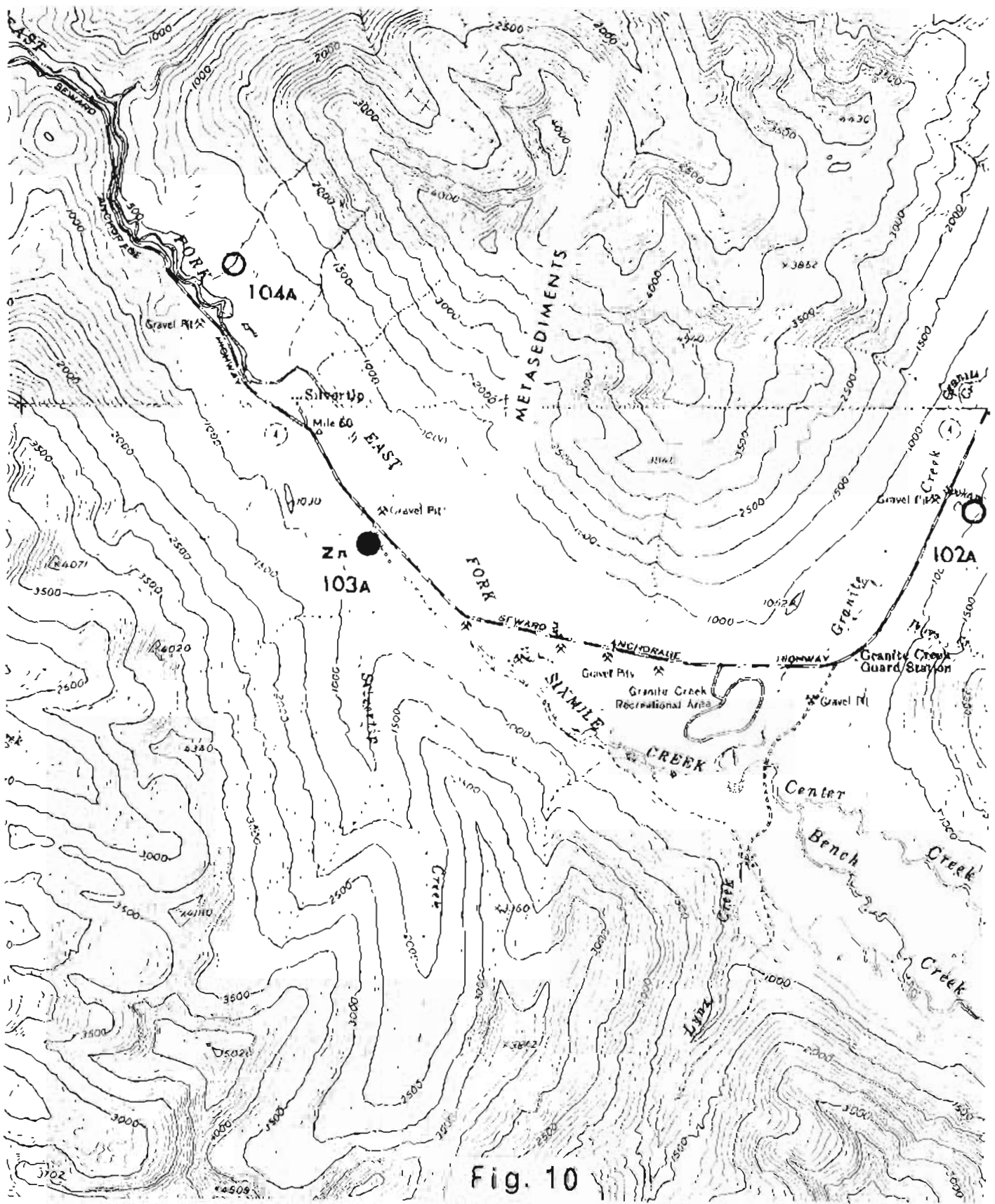




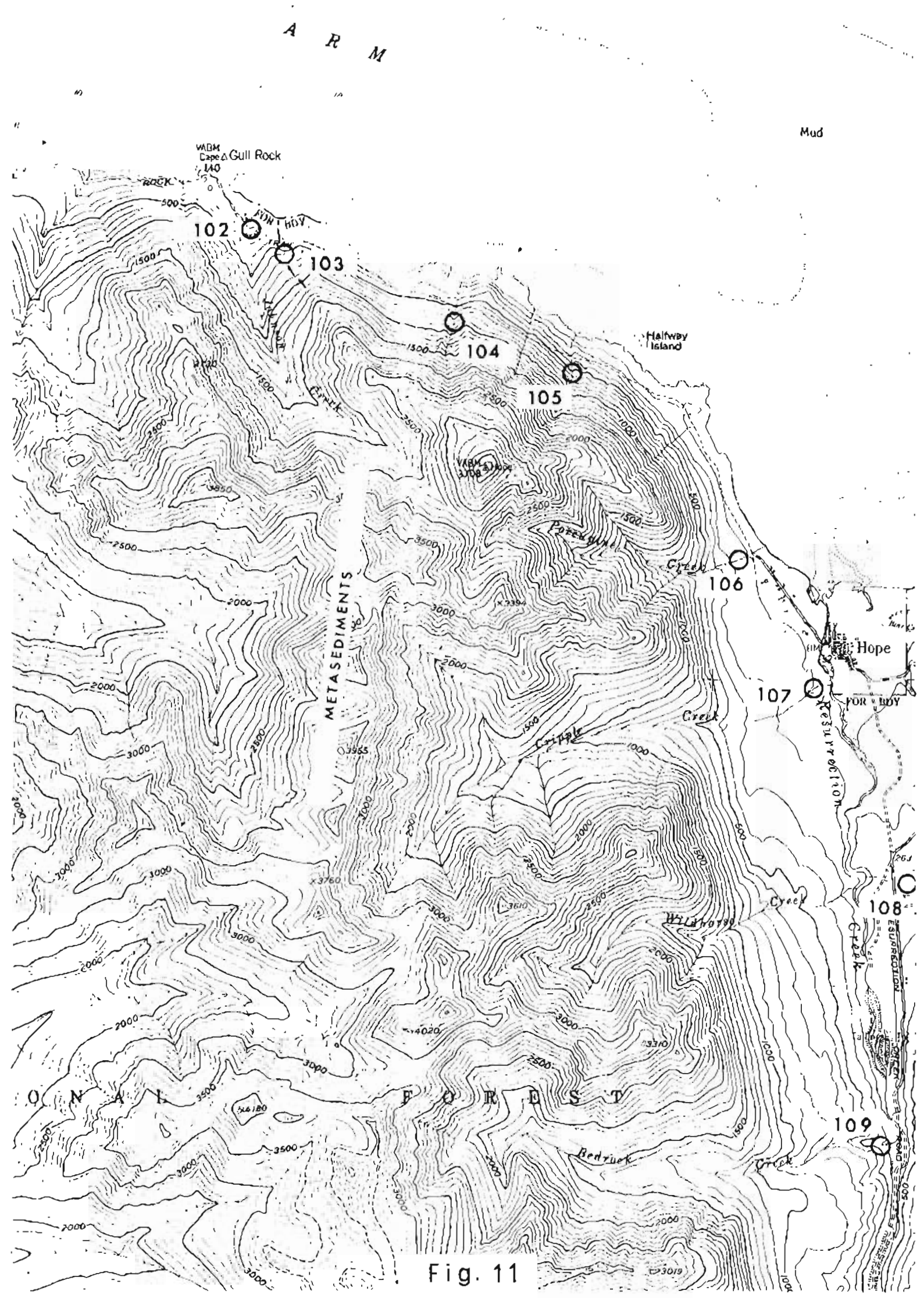




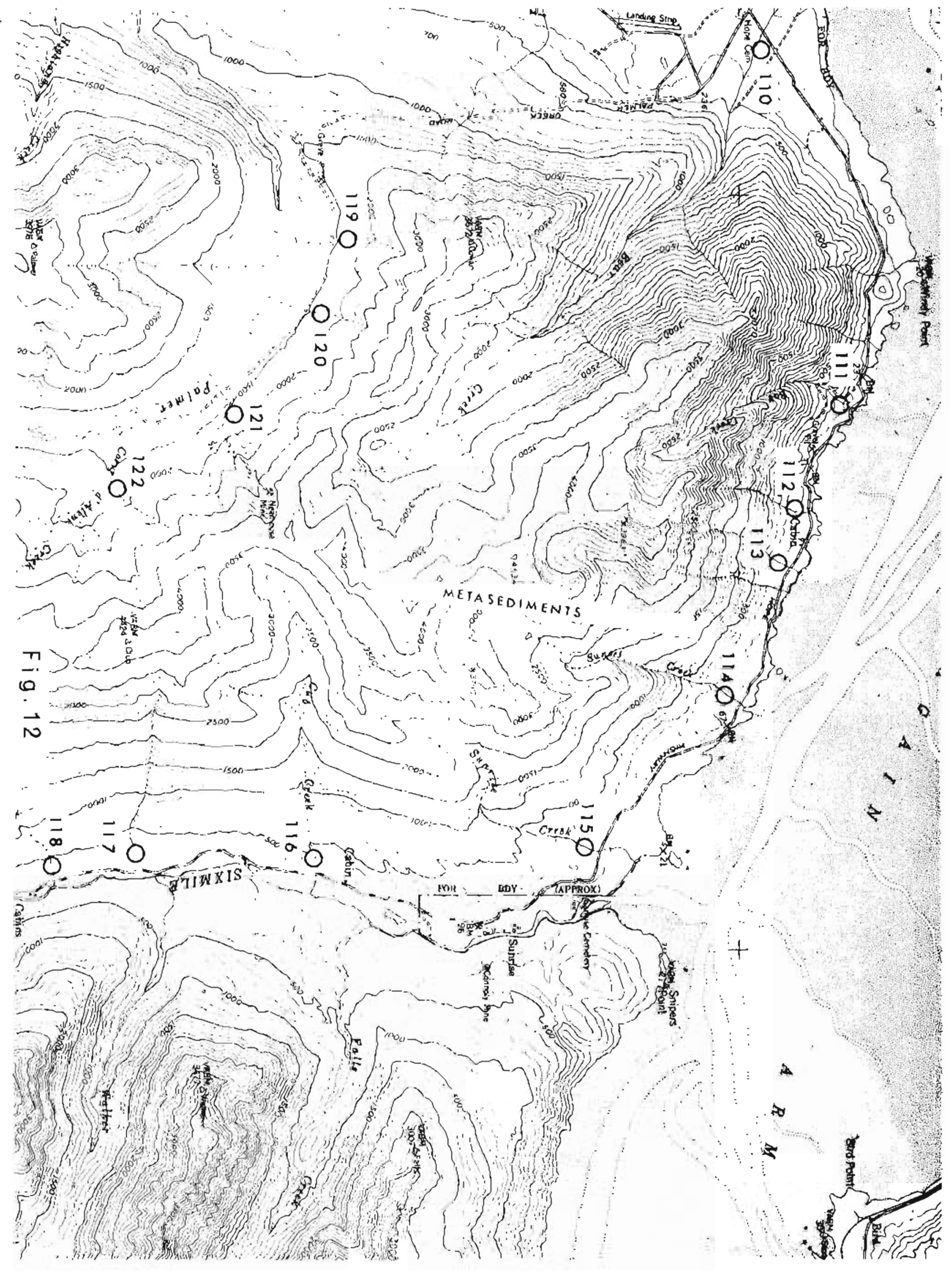




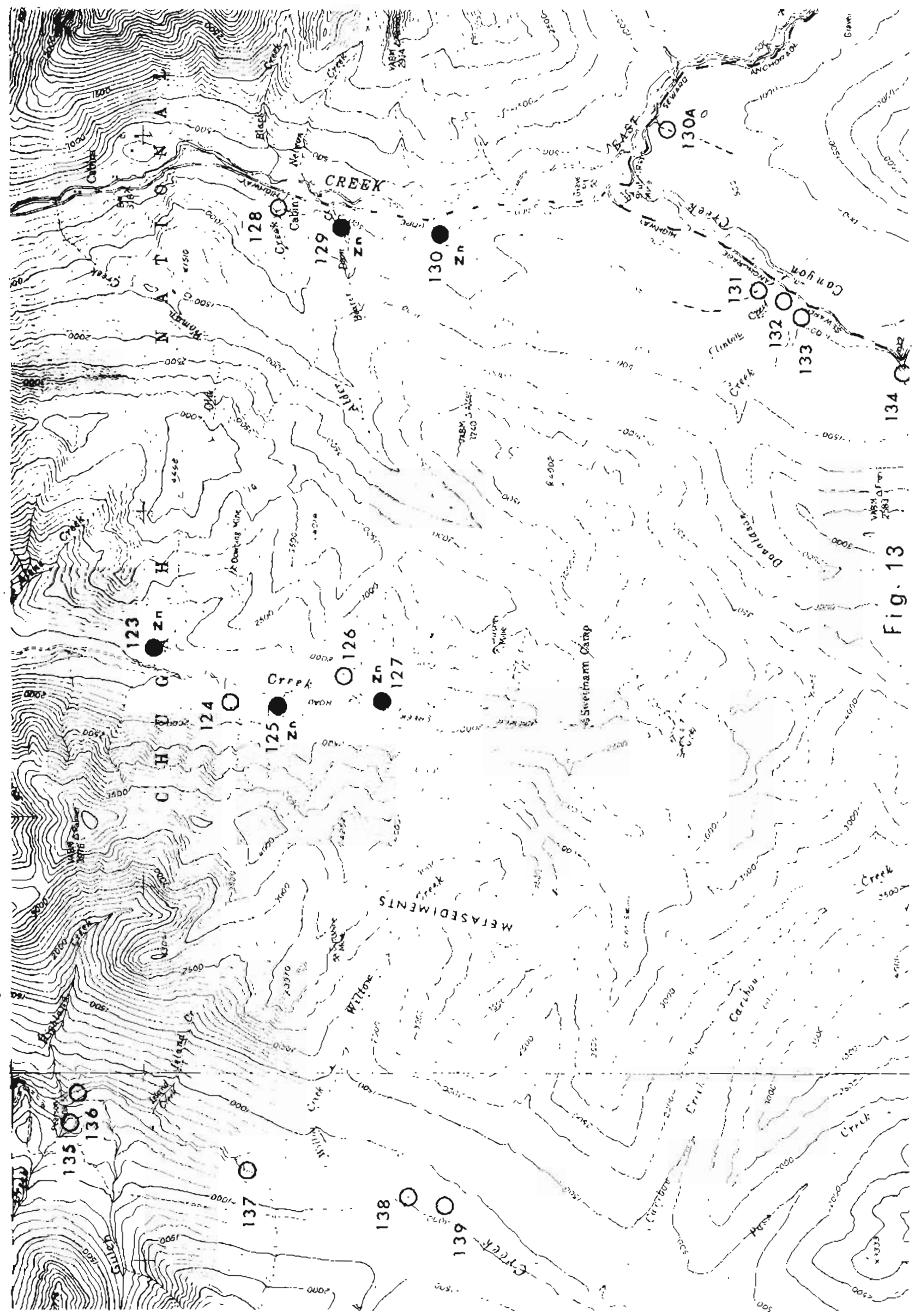




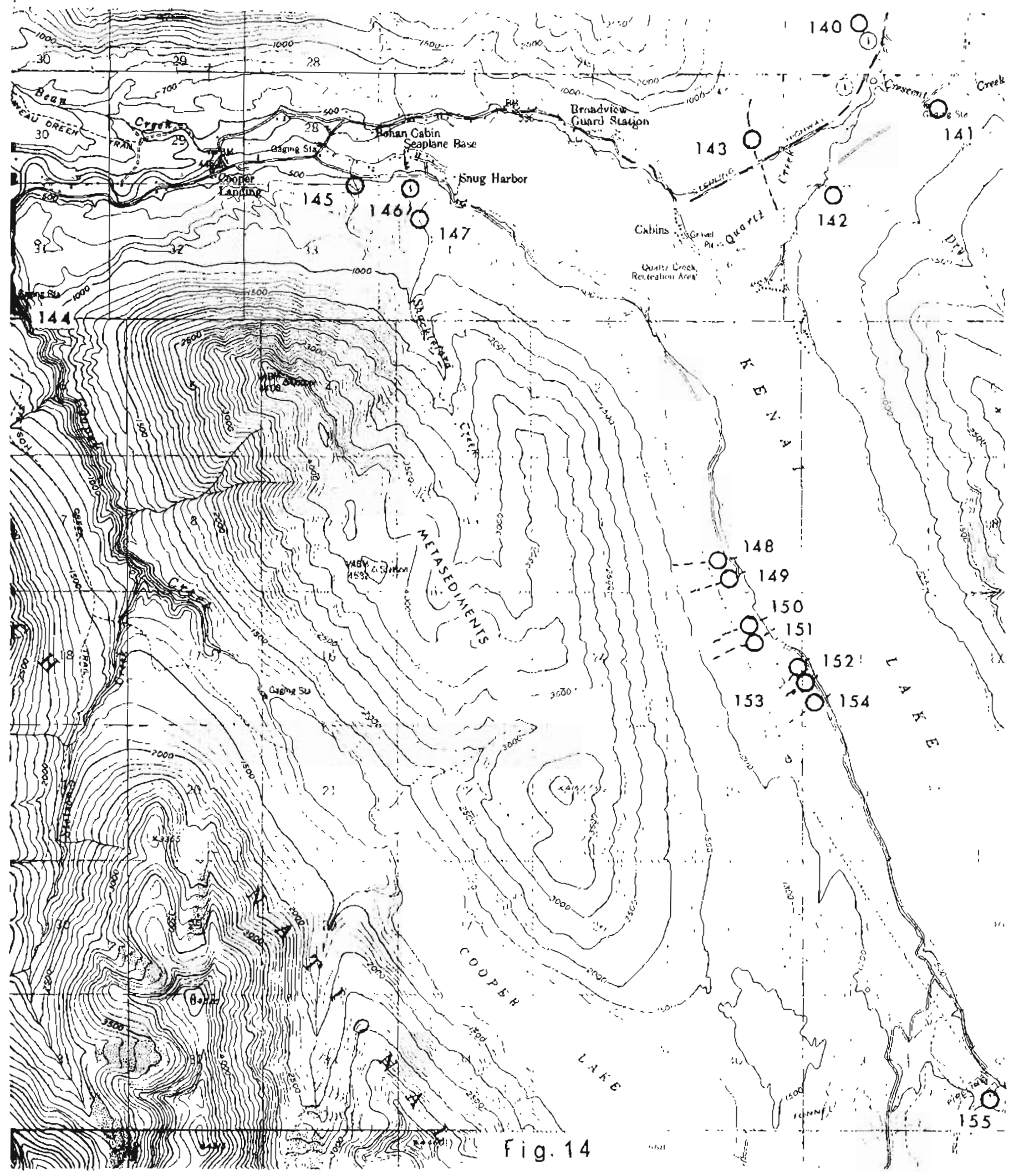




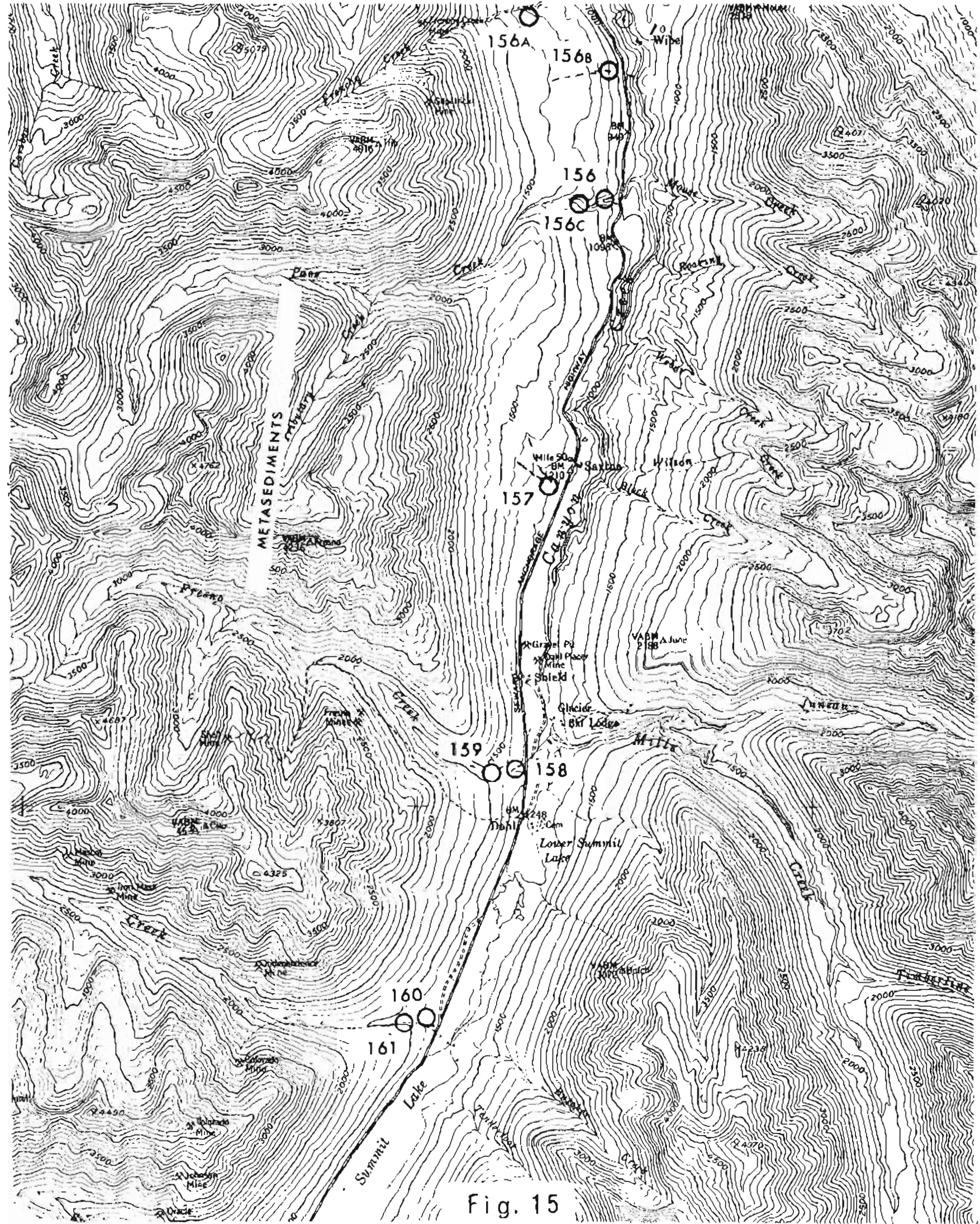




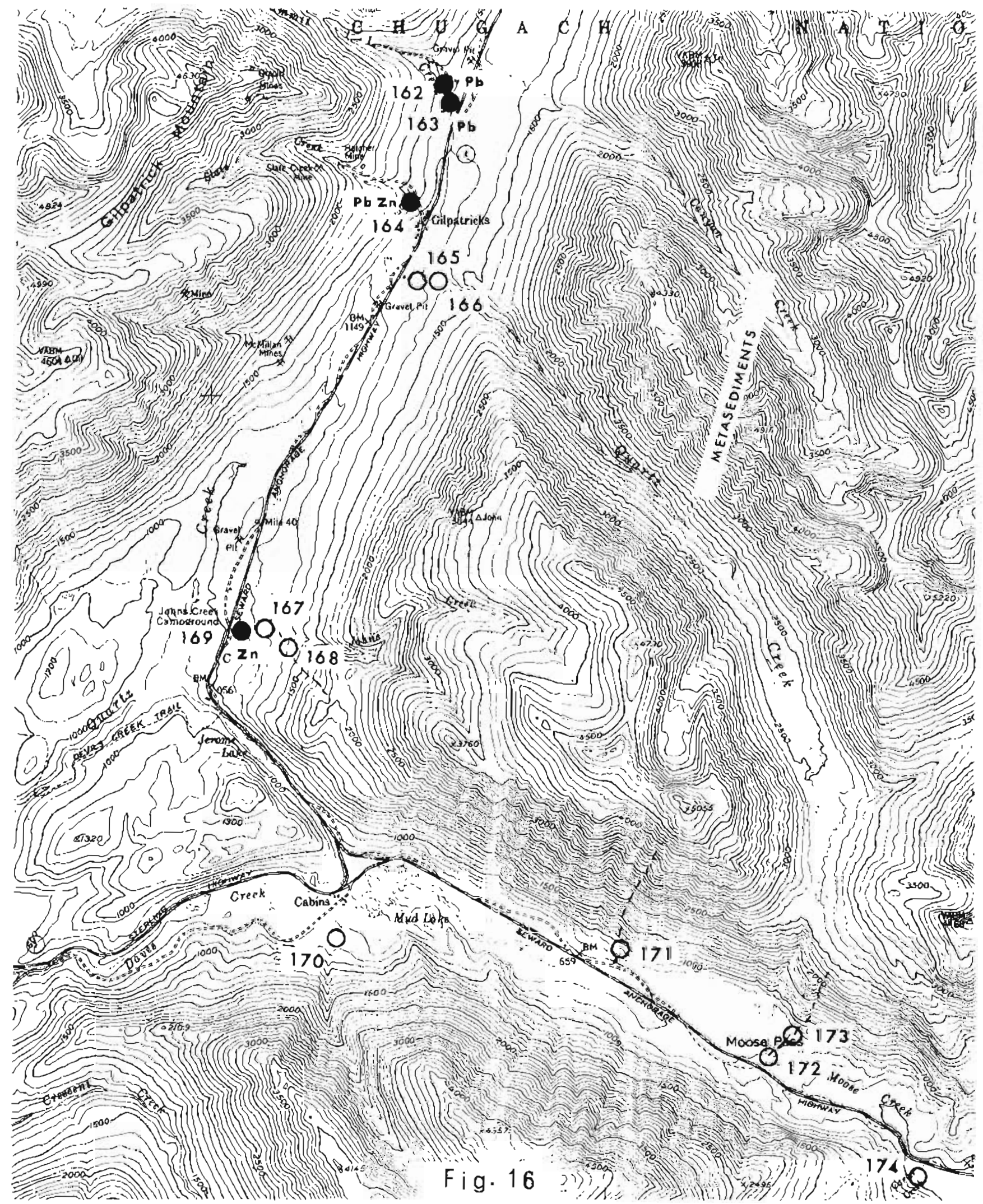




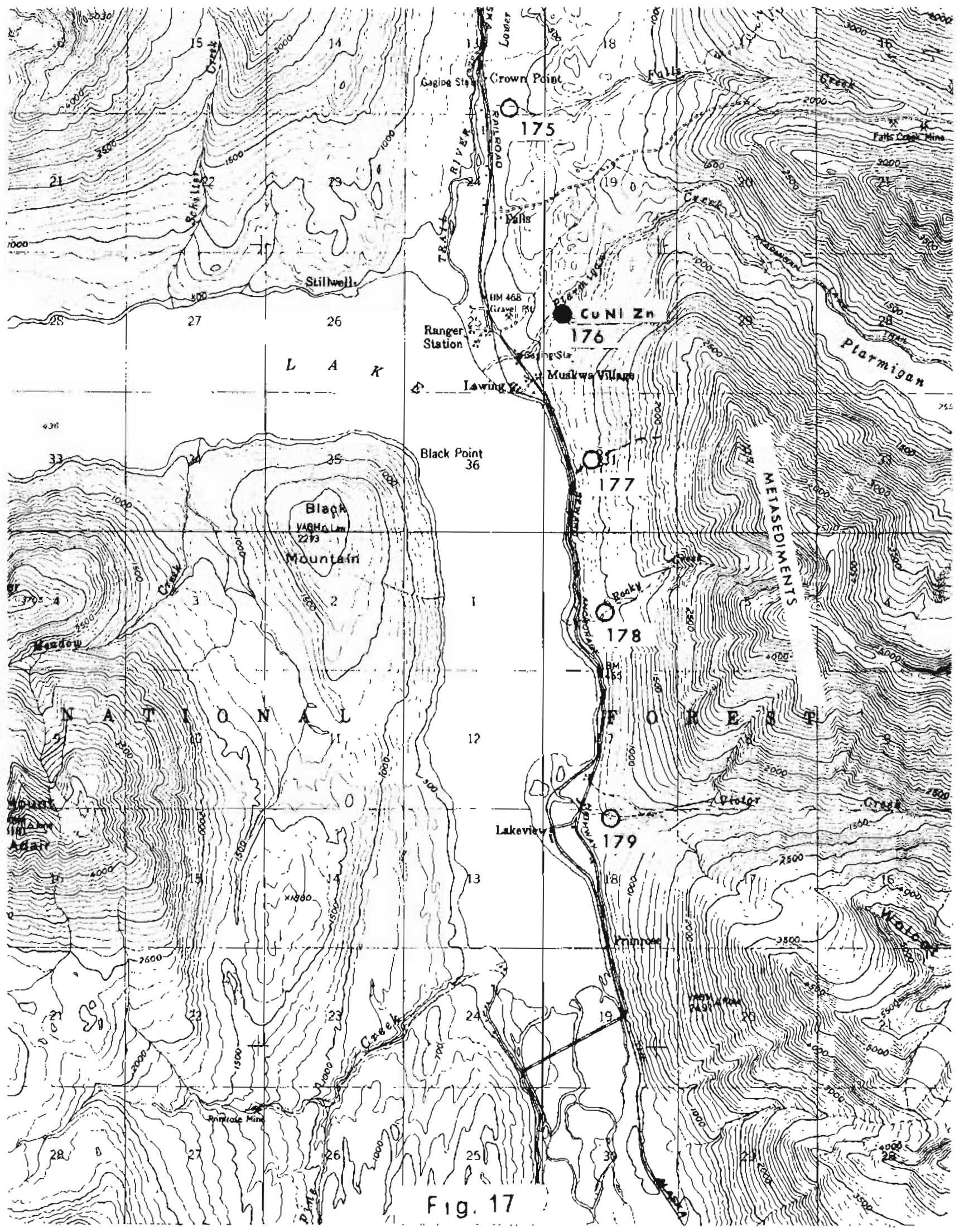




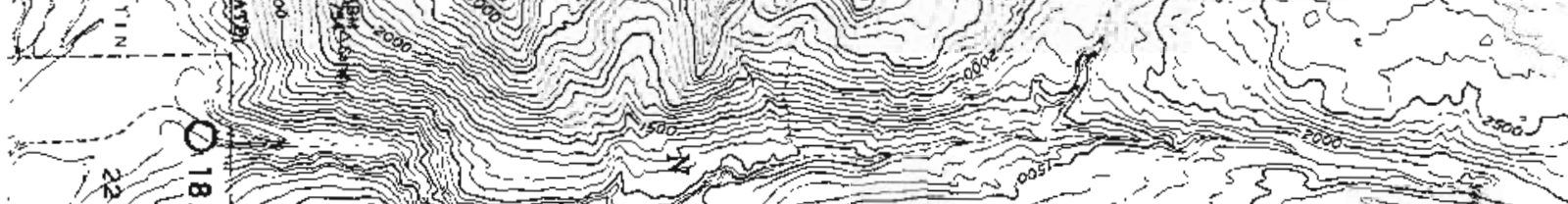

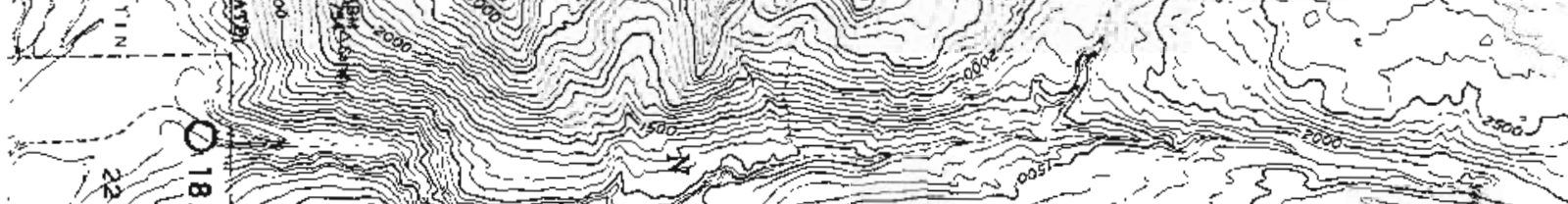

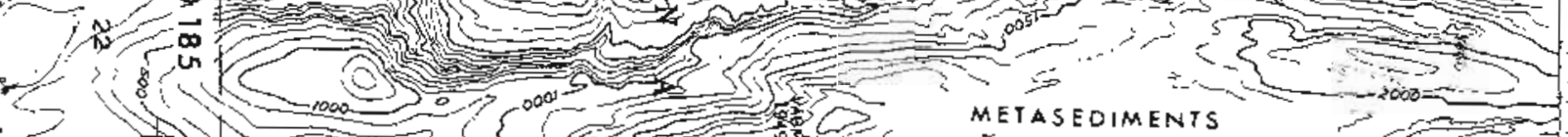
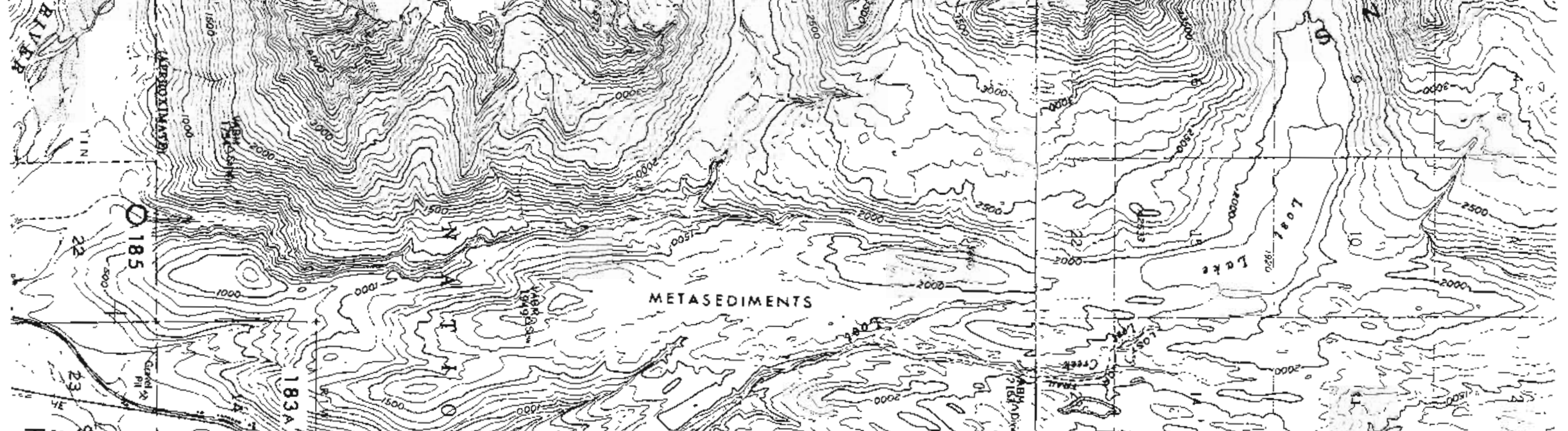

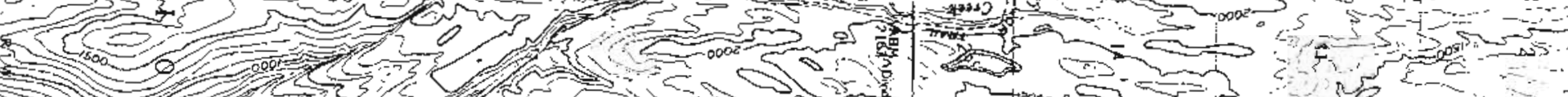

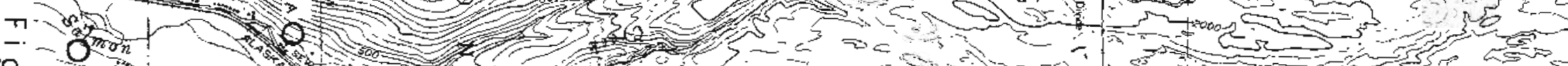
$0=-3$

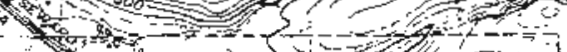

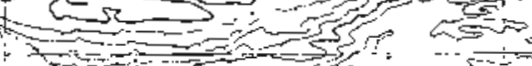

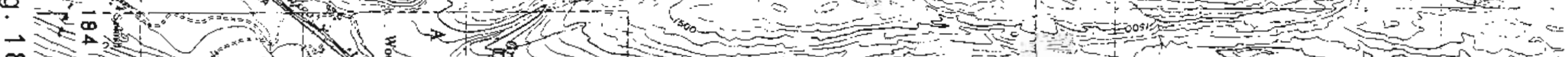

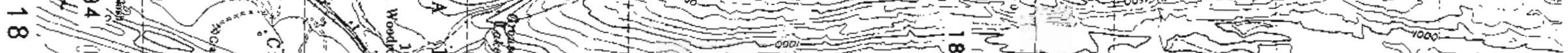

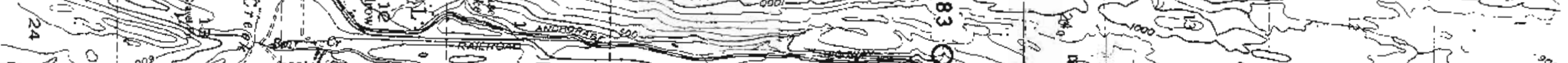
(20) in 1 (n) W. 1) WII

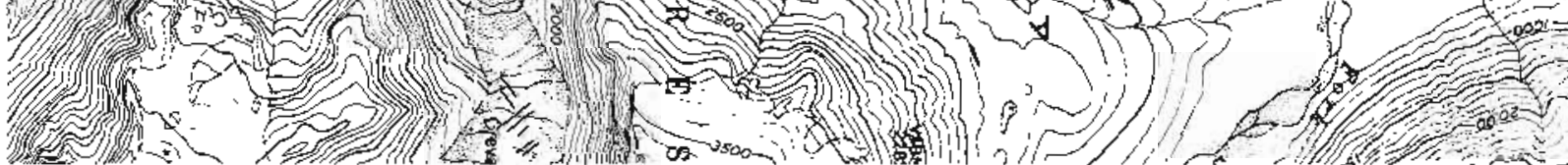

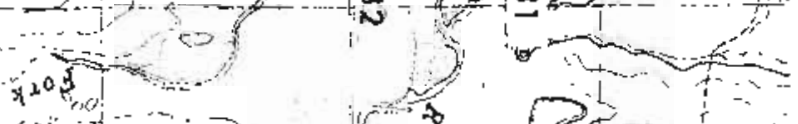




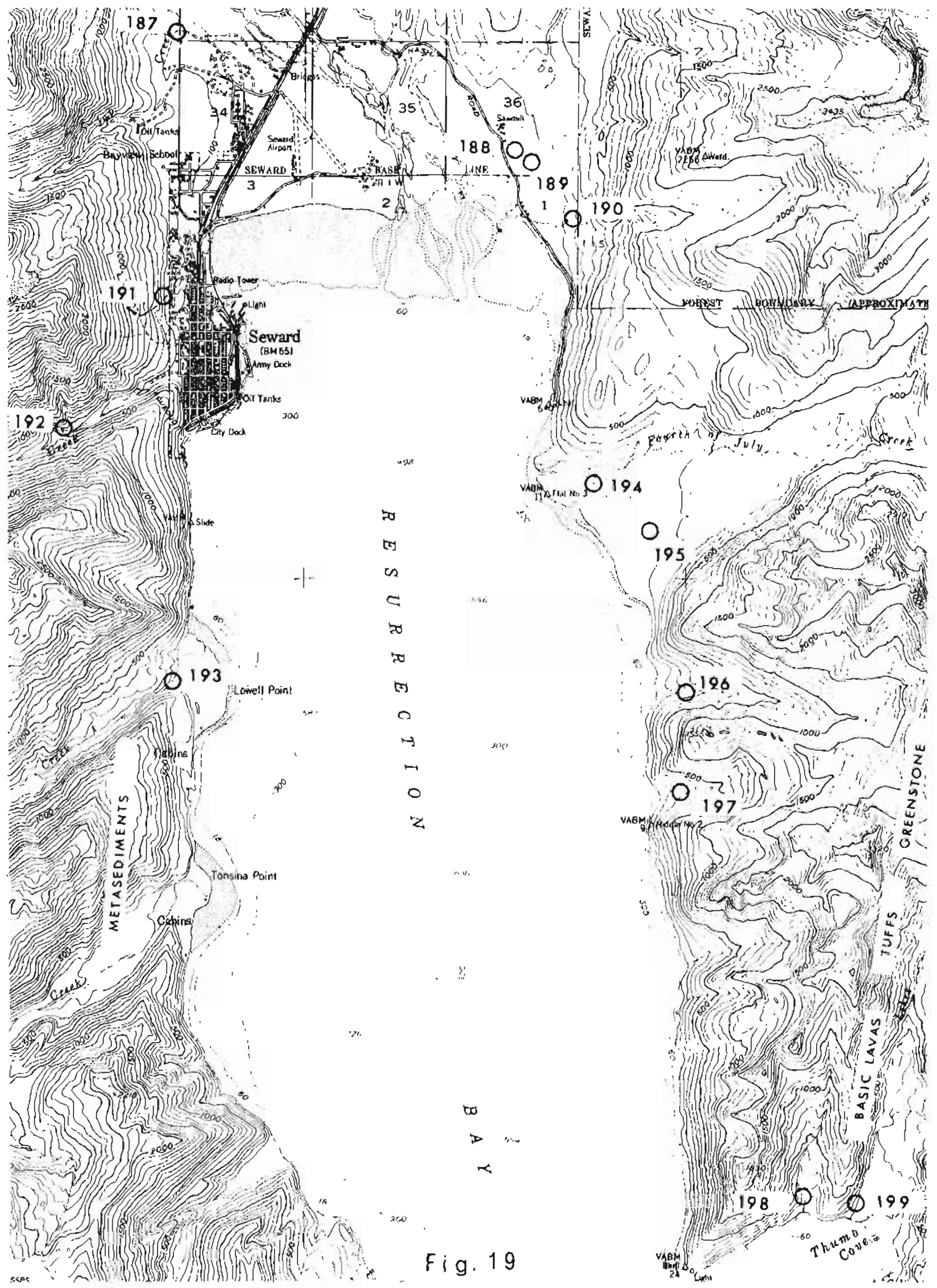


LITTLE SUSITNA RIVER, WILLOW CREEK DISTRICT

LONE TREE GULCH TO GAUGING STATION

Figure I
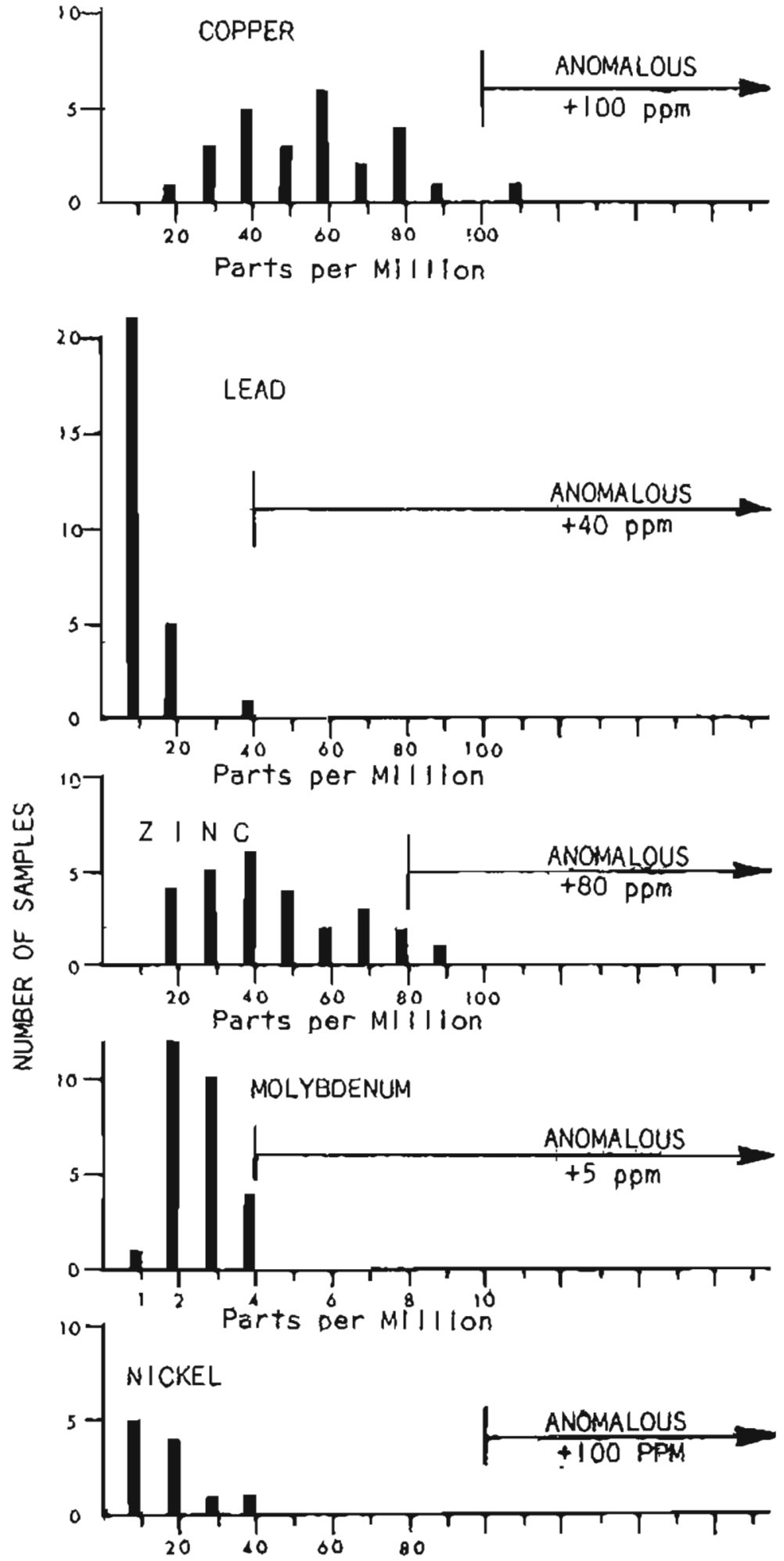
HIGHWAY STRIP AREA

WOLVERINE CREEK TO THUMB COVE, RESURRECTION BAY

FIGURES 2 to 19

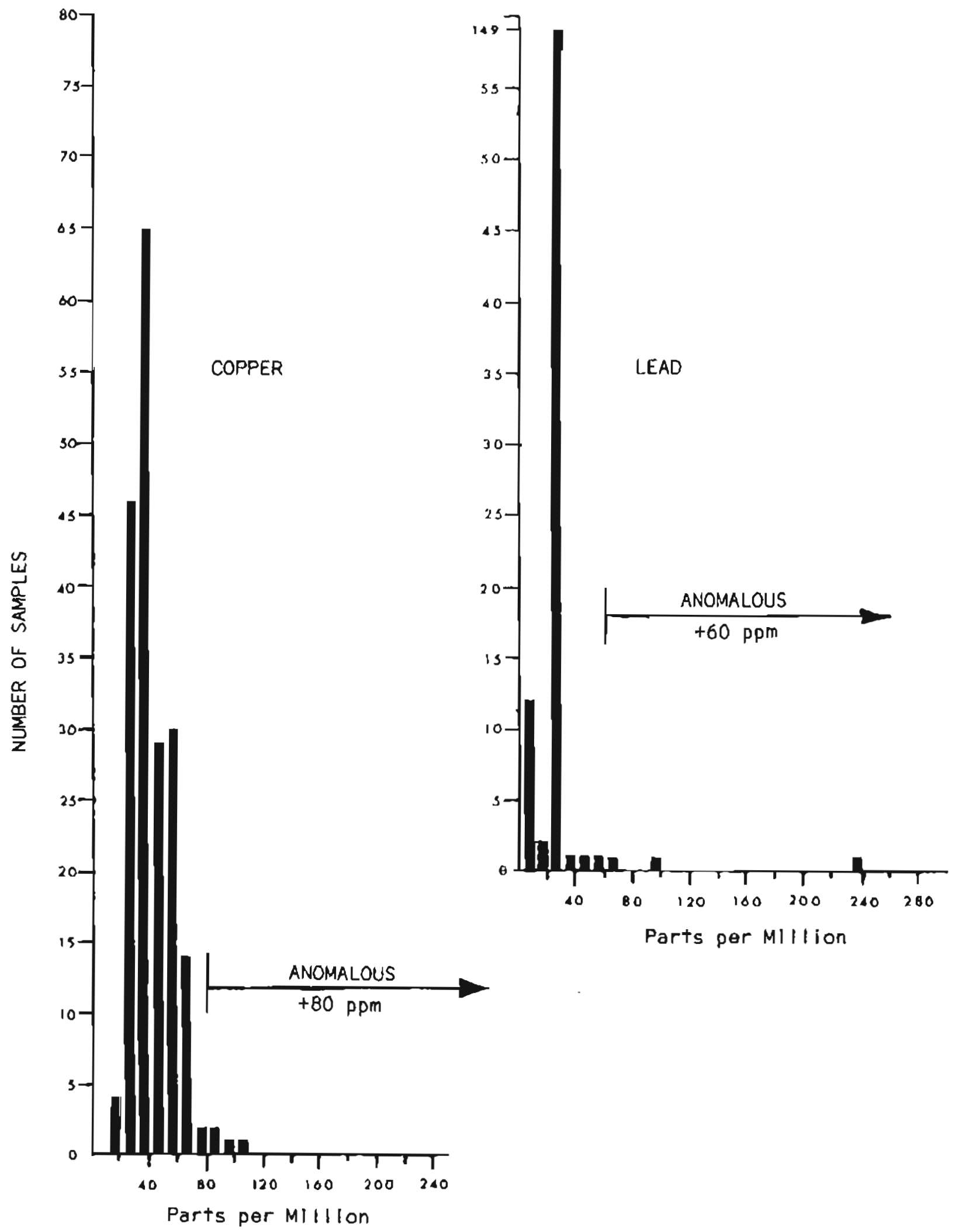


HIGHWAY STRIP AREA

WOLVERINE CREEK TO THUMB COVE, RESURRECTION BAY

FIGURES 2 to 19

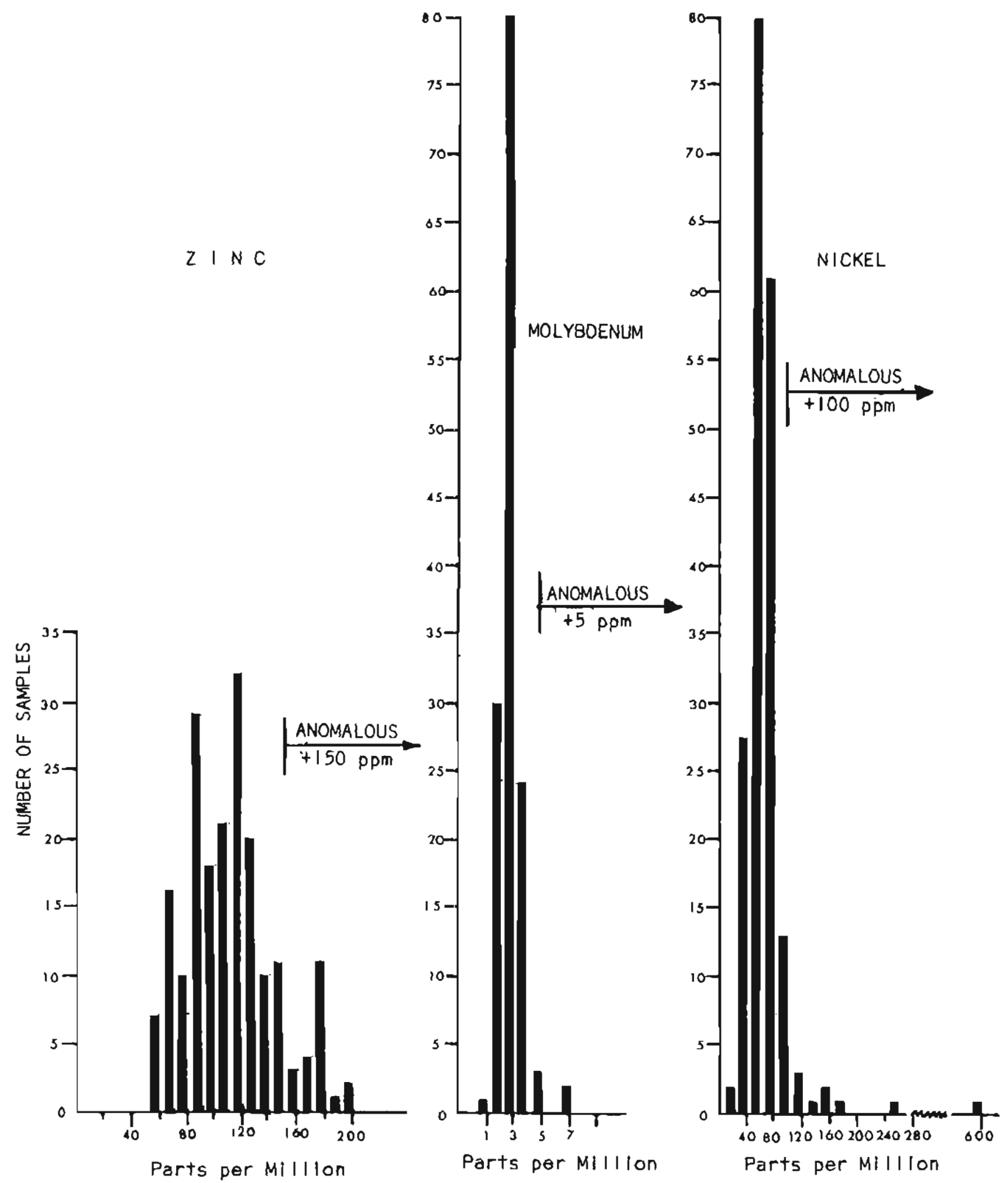




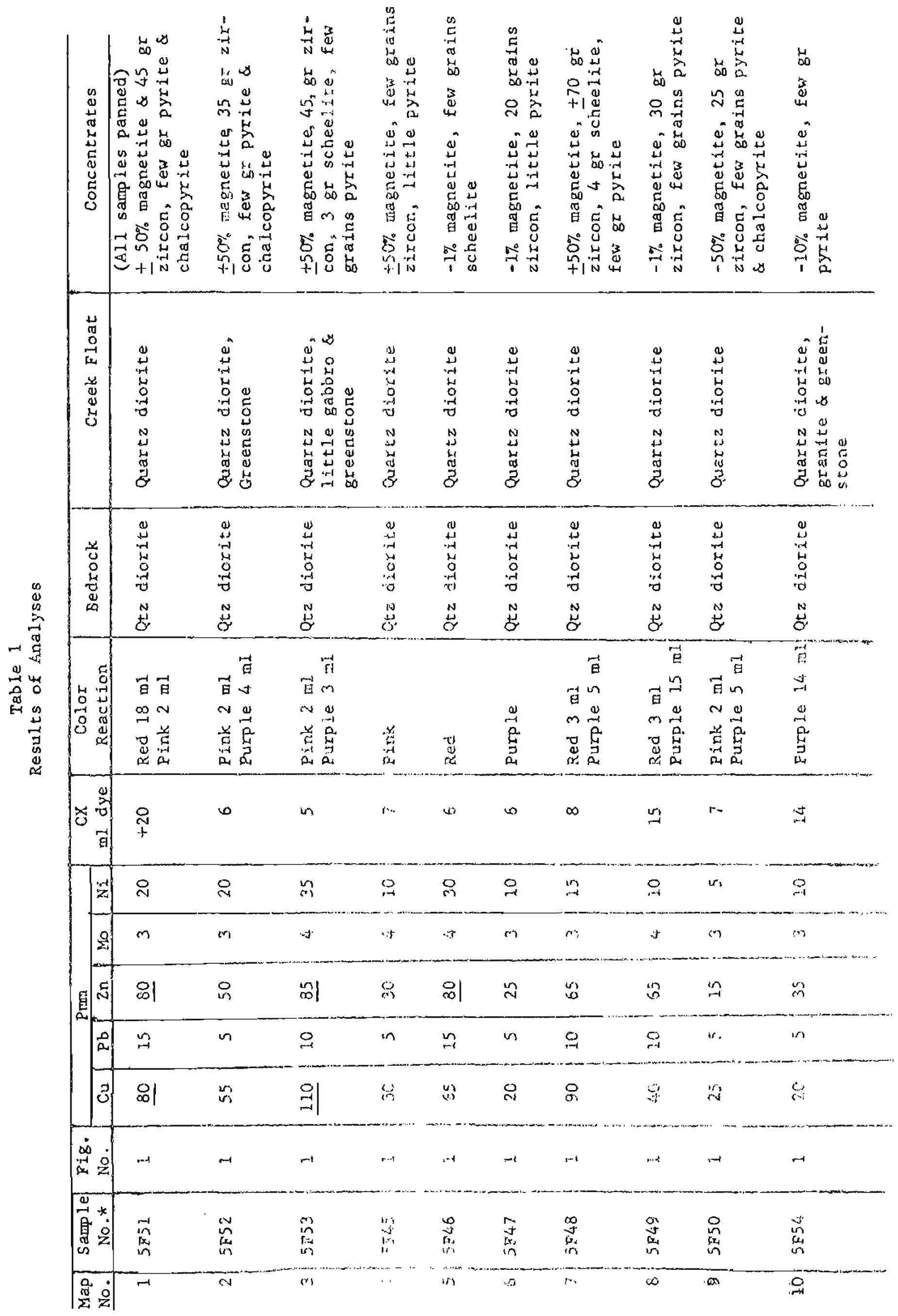




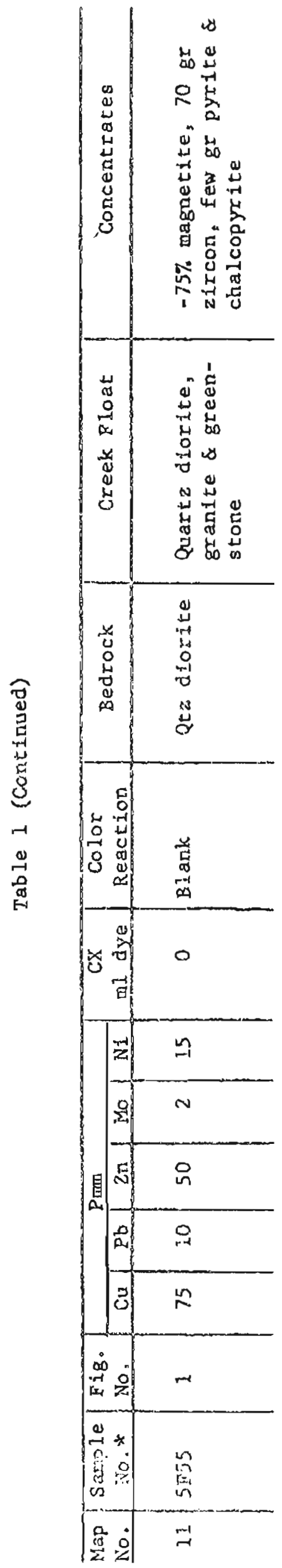

告

点

范

点

뭄

a)

兵

总 


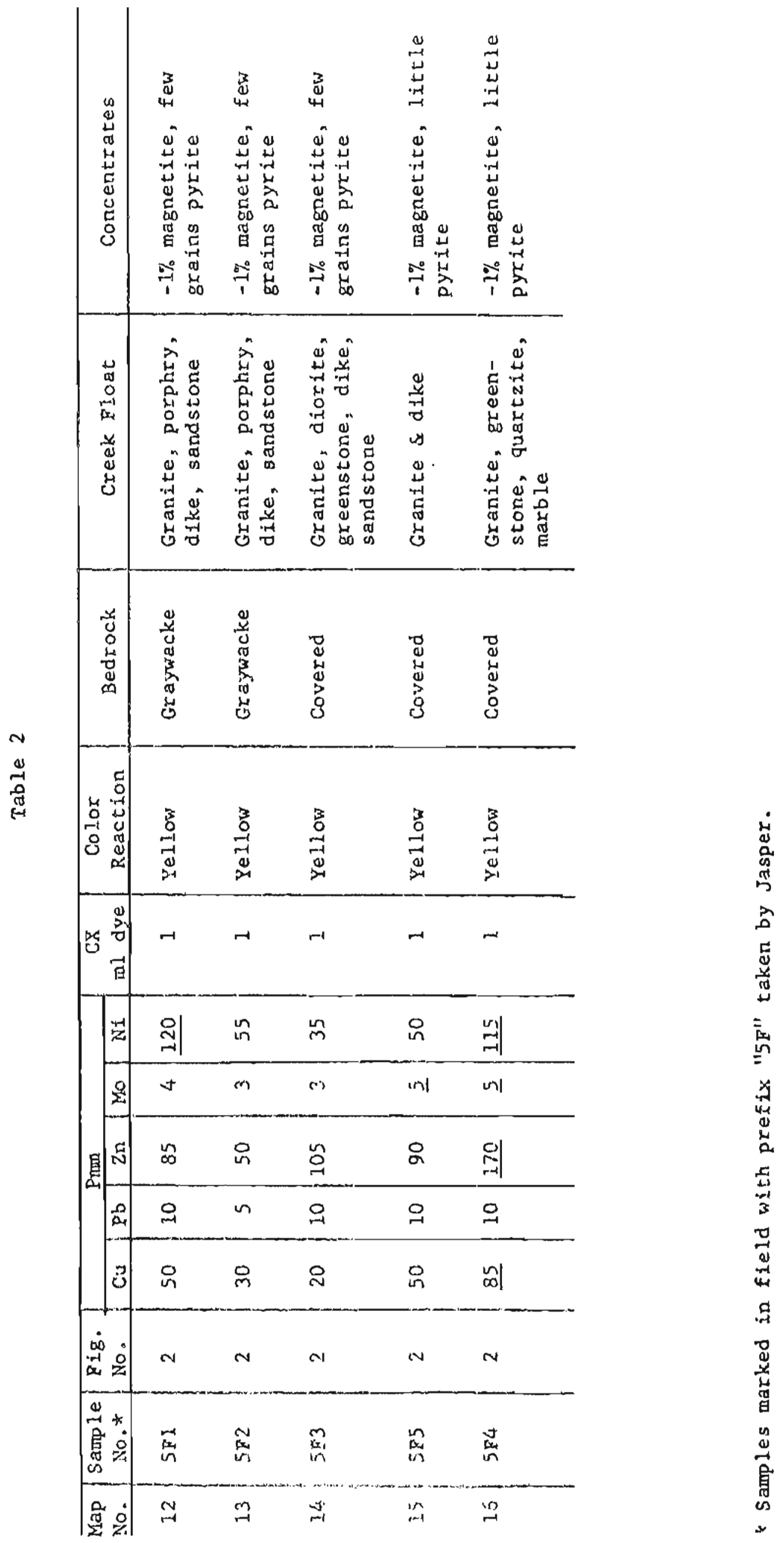


Tai: : 3

\begin{tabular}{|c|c|c|c|c|c|c|c|c|c|c|c|c|}
\hline \multirow{2}{*}{$\begin{array}{l}\text { Map } \\
\text { No. }\end{array}$} & \multirow{2}{*}{$\begin{array}{l}\text { Satip ie } \\
\text { No.* }\end{array}$} & \multirow{2}{*}{$\begin{array}{l}\text { Fig. } \\
\text { No. }\end{array}$} & \multicolumn{5}{|c|}{ Eप्रण्ण } & \multirow{2}{*}{$\begin{array}{l}\text { cx } \\
\text { aI dye }\end{array}$} & \multirow{2}{*}{$\begin{array}{l}\text { Solor } \\
\text { Reaction }\end{array}$} & \multirow{2}{*}{ Bedrock } & \multirow{2}{*}{ Creek Fioat } & \multirow{2}{*}{ Concentrates } \\
\hline & & & $\mathrm{Cu}$ & $\mathrm{Pb}$ & $2 n$ & Mo & $\mathrm{Ni}$ & & & & & \\
\hline 17 & $5 \geq 6$ & 3 & 50 & 15 & 110 & 3 & 55 & 1 & Ye $110 \mathrm{w}$ & Covered & $\begin{array}{l}\text { Granite, greenstone } \\
\text { graysacke }\end{array}$ & $\begin{array}{l}-1 \% \text { magnetite, little } \\
\text { pyite }\end{array}$ \\
\hline 28 & 527 & 3 & 55 & 15 & 140 & 3 & 65 & 1 & Yel low & Dike & $\begin{array}{l}\text { Granife, dike, } \\
\text { graywacke, sand- } \\
\text { stone }\end{array}$ & $\begin{array}{l}-1 \% \text { magnetite, } 11 t t \text { le } \\
\text { pyzite }\end{array}$ \\
\hline Is & $\$ 78$ & 3 & 35 & 10 & 120 & 4 & $4 \Xi$ & $\underline{1}$ & Yel Sow & Covered & $\begin{array}{l}\text { Granite, dike, } \\
\text { graywacke, sand- } \\
\text { stone }\end{array}$ & $\begin{array}{l}-17 \text { magnetite, littie } \\
\text { pyrite }\end{array}$ \\
\hline$\infty 0$ & 5.59 & 3 & 20 & 30 & 110 & 4 & 50 & 3 & Yel 10: & Covered & $\begin{array}{l}\text { Greenstone, line- } \\
\text { stone, quartzite, } \\
\text { breccia. }\end{array}$ & $\begin{array}{l}-1 \% \text { wagnetite, } 3 \mathrm{gr} \text { zircon, } \\
\text { little pyrite }\end{array}$ \\
\hline 21 & 58160 & 3 & & & MPLE & LOST & & & & & $\begin{array}{l}\text { Graywacke, ultra- } \\
\text { matics }\end{array}$ & $\begin{array}{l}-10 \% \text { magnetite, } 8 \% \\
\text { chromium, } 10 \mathrm{gr} \text { zircon }\end{array}$ \\
\hline 22 & $5=201$ & 3 & 50 & 10 & 135 & 3 & 600 & 3 & & Covered & $\begin{array}{l}\text { Graywacke } \alpha \\
\operatorname{argil1ite}\end{array}$ & $\begin{array}{l}-10 \% \text { magnetite, } 13 \% \\
\text { chromium, } 10 \mathrm{gr} \text { zircon }\end{array}$ \\
\hline 23 & $5+44$ & 3 & 45 & 15 & 140 & 3 & 40 & 4 & Putple & Covered & $\begin{array}{l}\text { Greenstone, granite, } \\
\text { sandstone, } \\
\text { argilitte }\end{array}$ & $-1 \%$ magnetite \\
\hline 24 & $5 \mathrm{E} 202$ & 3 & 35 & 10 & 135 & 2 & 60 & 3 & & Covered & $\begin{array}{l}\text { Greenstone, } \\
\text { argillite }\end{array}$ & $\begin{array}{l}0.7 \% \text { chromlum, } 10 \mathrm{gr} \\
\text { zircon, }-5 \% \text { wagnetite }\end{array}$ \\
\hline
\end{tabular}

* Samples marked tn fLid wish prefix "5F" taken by jasper. samples marked in field with prefix "5E" taker by Rose. 


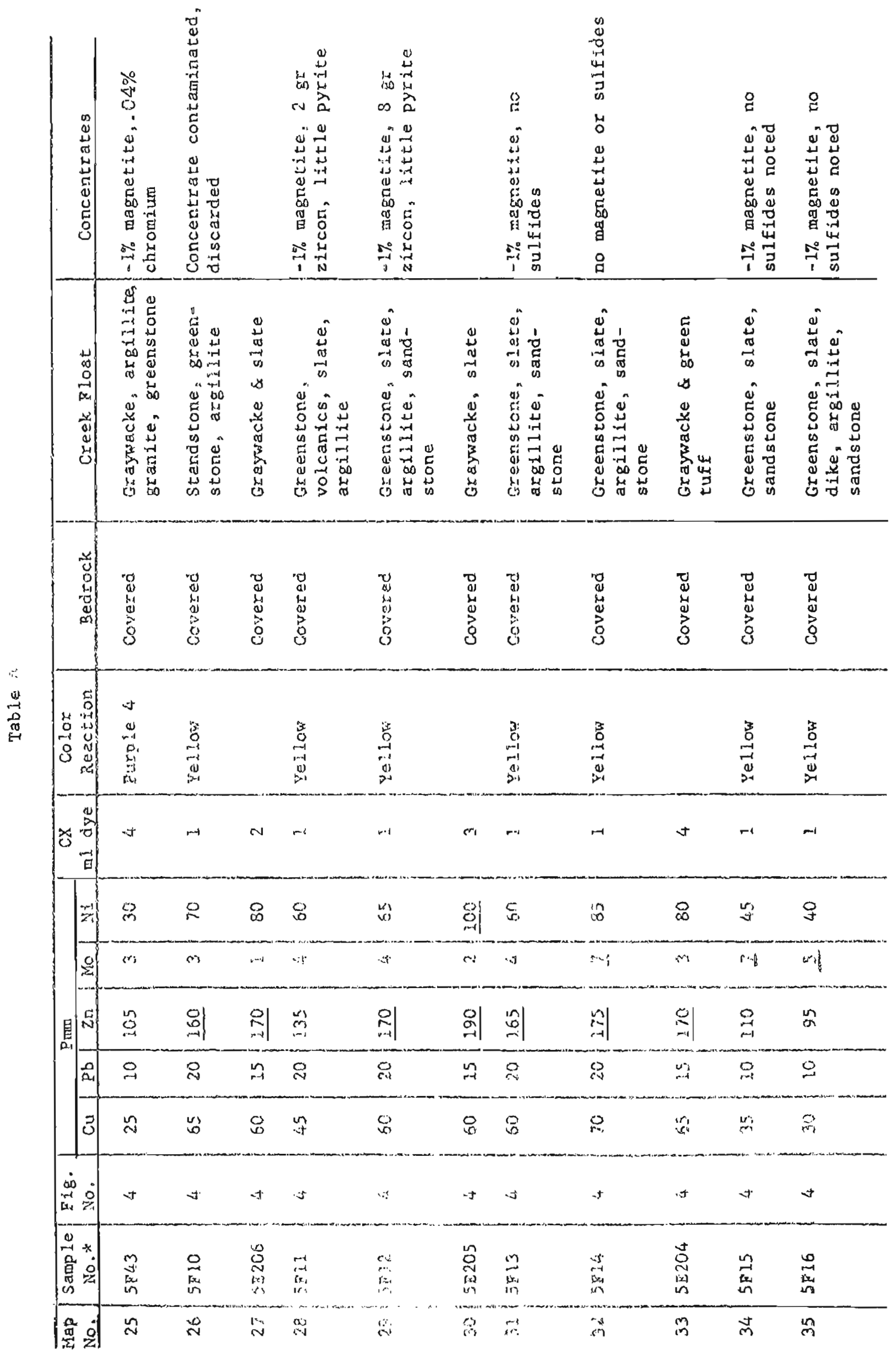




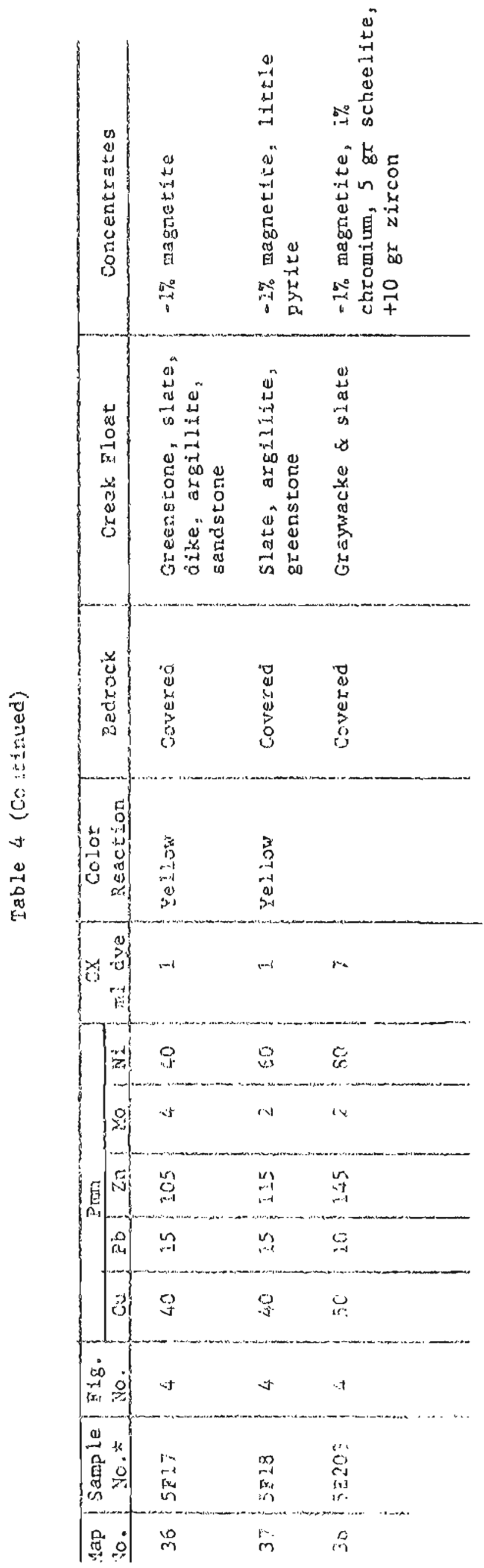

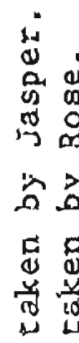

$\bar{v}_{2}$ n

ic $y$

in a

in $x$

步点

急

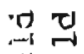

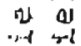

ind $4-1$

is

ta

要

施

क क ल

rat

些量 


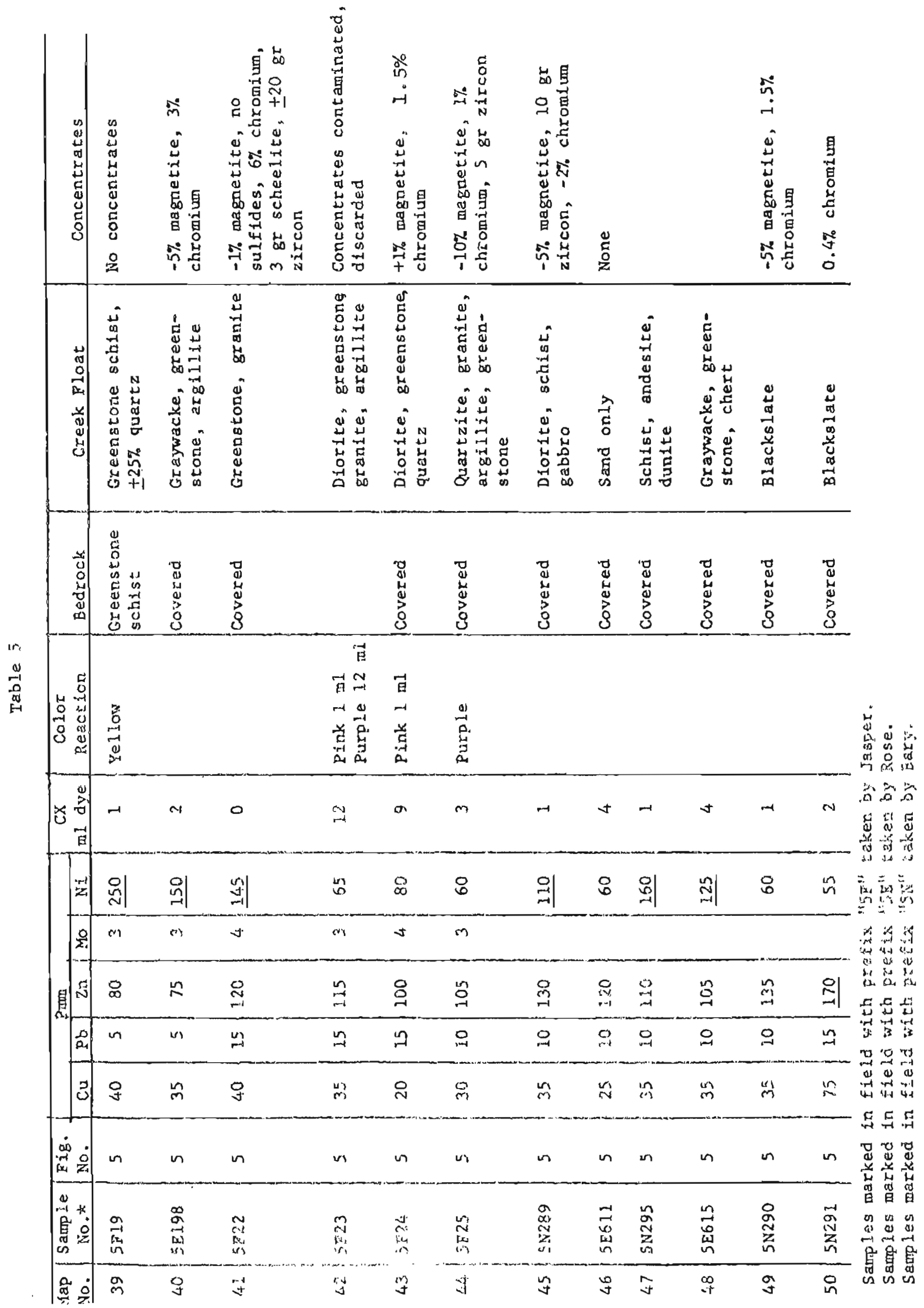




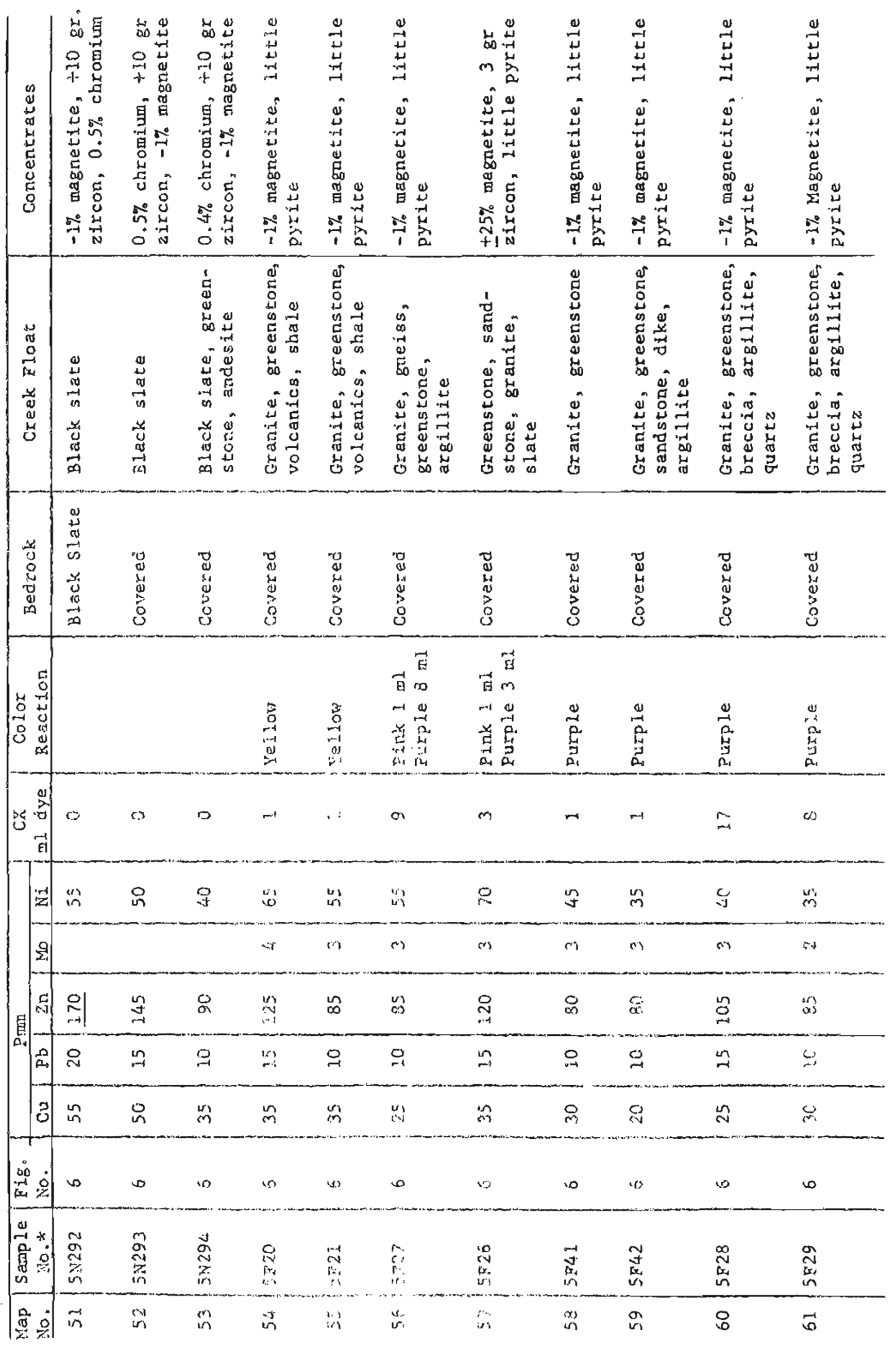


Table 6 (Constinted)

\begin{tabular}{|c|c|c|c|c|c|c|c|c|c|c|c|c|}
\hline \multirow{2}{*}{$\begin{array}{l}\text { Map } \\
\text { Mo. }\end{array}$} & \multirow{2}{*}{$\begin{array}{c}\text { Samole } \\
\text { No:\% }\end{array}$} & \multirow{2}{*}{$\begin{array}{l}\text { Fig. } \\
\text { No. }\end{array}$} & \multicolumn{5}{|c|}{$2 \pi$} & \multirow{2}{*}{$\begin{array}{c}c x \\
\text { mi dye }\end{array}$} & \multirow{2}{*}{$\begin{array}{c}\text { Color } \\
\text { Reaction }\end{array}$} & \multirow[b]{2}{*}{ Bedrock } & \multirow{2}{*}{ Creek Float } & \multirow{2}{*}{ Concentrates } \\
\hline & & & $\mathrm{Cu}$ & $P$ & $z=$ & 10 & 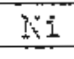 & & & & & \\
\hline 62 & $5 F 30$ & 6 & 35 & 20 & 130 & 3 & 20 & 8 & 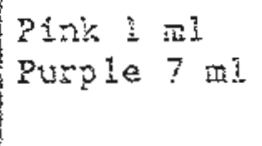 & coverad & $\begin{array}{l}\text { Granite, greensione, } \\
\text { brecola, argilitte, } \\
\text { quartz }\end{array}$ & $\begin{array}{l}-1 \% \text { magnetite, lictle } \\
\text { pyrite }\end{array}$ \\
\hline 53 & $5: 31$ & 6 & 50 & 20 & 140 & 3 & 35 & 7 & $p+i e-G a y$ & covered & $\begin{array}{l}\text { Granite, greenstone, } \\
\text { breccia, argillite, } \\
\text { guarta }\end{array}$ & $\begin{array}{l}-1 \% \text { gagnetite, littie } \\
\text { pyrite }\end{array}$ \\
\hline 64 & 5832 & 5 & 35 & 15 & 100 & 3 & 45 & 3 & Futpie & Coreseds & $\begin{array}{l}\text { Grenite, greenstone, } \\
\text { breccia, aroilitte, } \\
\text { guartz }\end{array}$ & $\begin{array}{l}\text { - } 1 \% \text { magnetite, iittle } \\
\text { pyrite, } 5 \text { gr zircon }\end{array}$ \\
\hline$\because$ & 5233 & 5 & 30 & 10 & 80 & 3 & 70 & $\Xi$ & $\begin{array}{l}\text { Pink I mi } \\
\text { Pale plerpie } \\
\quad 2 \text { ml }\end{array}$ & Couered & $\begin{array}{l}\text { Greenstone, granite, } \\
\text { breccia, porphyry, } \\
\text { sandstone, quartz, } \\
\text { argillite }\end{array}$ & No concentrates \\
\hline 66 & 5834 & 6 & 30 & 10 & 95 & 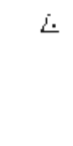 & 45 & 2 & $p i n k$ & Covezed & $\begin{array}{l}\text { Granite, greenstore, } \\
\text { dike, porphyry, } \\
\text { sandstone, quartz }\end{array}$ & $\begin{array}{l}\text {-1\% magnetite, little } \\
\text { pyrite }\end{array}$ \\
\hline $6 i$ & 5535 & 5 & 40 & 15 & 220 & 4 & 50 & 3 & $\begin{array}{l}\text { Fink } 1 \mathrm{ml} \\
\text { Furple } 2 \mathrm{ml}\end{array}$ & Covered & $\begin{array}{l}\text { Grarite, greenstone, } \\
\text { dike, porphyry, } \\
\text { sandstone, quartz }\end{array}$ & Contaminated, discarded \\
\hline 68 & $5 F 36$ & 6 & 5 & 20 & 85 & $\Sigma$ & 50 & 13 & $\begin{array}{l}\text { Red } 4 \mathrm{nI} \\
\text { Purpie } 9 \mathrm{mi}\end{array}$ & Covered & $\begin{array}{l}\text { Granite, greenstone, } \\
\text { dike, porphyry, } \\
\text { sandstone, quartz }\end{array}$ & Contaminated, discarded \\
\hline 69 & 5737 & 6 & 35 & 10 & 105 & 4 & 60 & 3 & $\begin{array}{l}\text { Pink } 1 \mathrm{ml} \\
\text { Purple } 2 \mathrm{ml}\end{array}$ & Covered & $\begin{array}{l}\text { Grenite, greenstone, } \\
\text { dike, porphyry, } \\
\text { sandstone, quartz }\end{array}$ & None noted \\
\hline 70 & $5 F 38$ & 6 & 25 & 10 & iio & 3 & 60 & 3 & $\begin{array}{l}\text { Pink } \mathrm{i} \text { 如l } \\
\text { Purple } 2 \mathrm{mi}\end{array}$ & Covered & $\begin{array}{l}\text { Granite, greenstone, } \\
\text { dike, porphyry, } \\
\text { sandstone, quartz }\end{array}$ & $\begin{array}{l}-1 \% \text { magnetite, little } \\
\text { pyrite }\end{array}$ \\
\hline
\end{tabular}




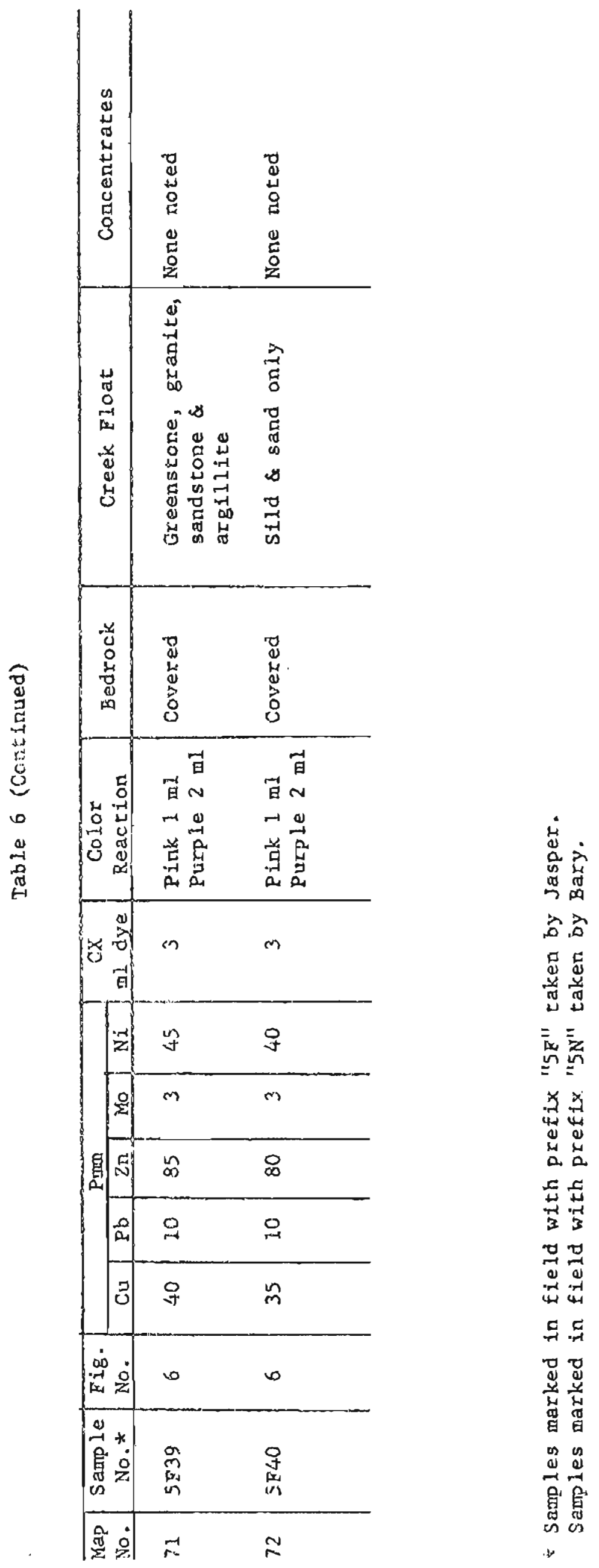




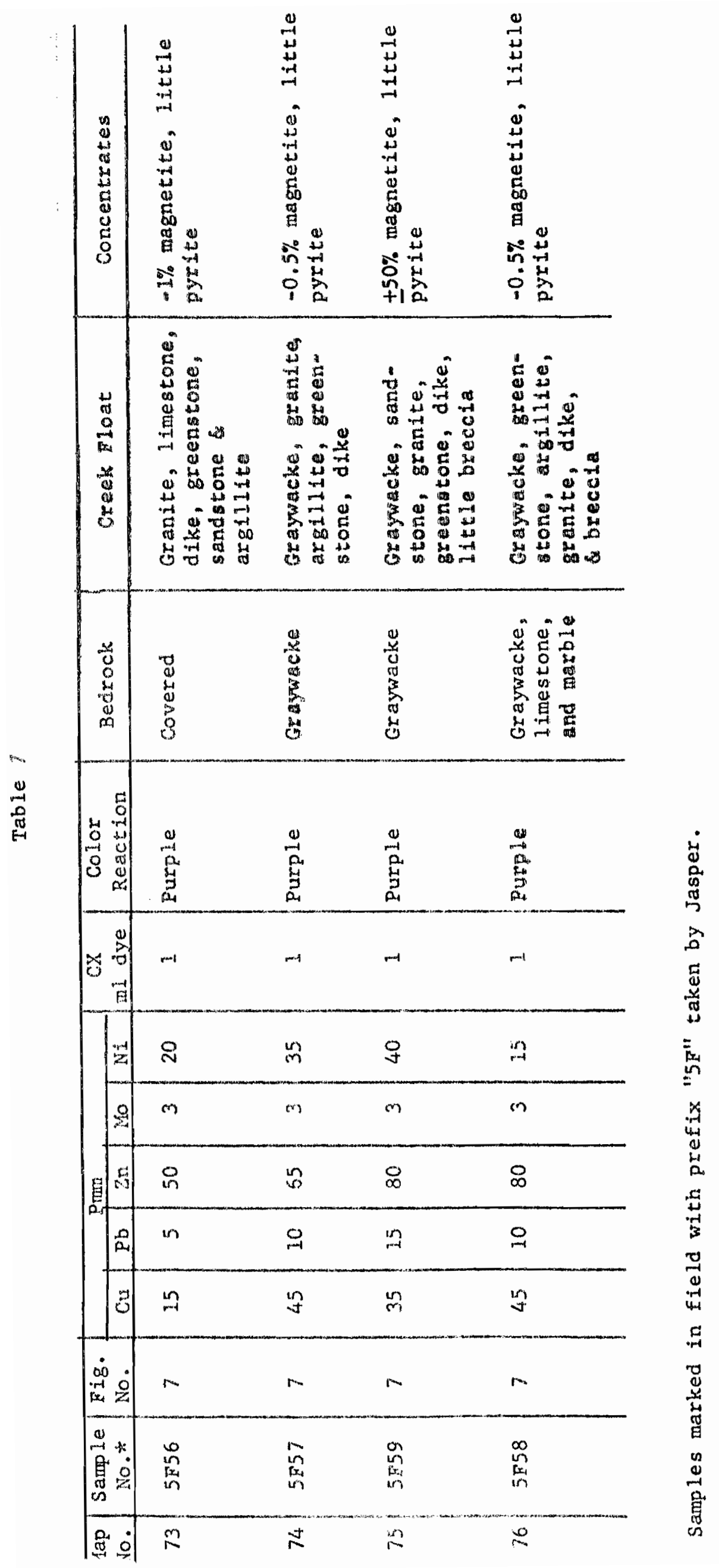


Table 3

\begin{tabular}{|c|c|c|c|c|c|c|c|c|c|c|c|c|}
\hline \multirow{2}{*}{$\begin{array}{l}\text { lap } \\
0 .\end{array}$} & \multirow{2}{*}{$\begin{array}{c}\text { Samp le } \\
\text { No. } \frac{1}{x}\end{array}$} & \multirow{2}{*}{$\begin{array}{l}\text { Fig. } \\
\text { No. }\end{array}$} & \multicolumn{5}{|c|}{ Enim } & \multirow{2}{*}{$\begin{array}{l}\text { CX } \\
\text { mi dye }\end{array}$} & \multirow{2}{*}{$\begin{array}{c}\text { Color } \\
\text { Reaction }\end{array}$} & \multirow[b]{2}{*}{ Bedrock } & \multirow{2}{*}{ Creek Float } & \multirow{2}{*}{ Concentrates } \\
\hline & & & $\mathrm{Cu}$ & $\mathrm{Pb}$ & $\mathrm{Zn}$ & 10 & $\mathrm{NL}$ & & & & & \\
\hline 77 & 5960 & 8 & 35 & 20 & 95 & 3 & 55 & 0 & Blank & Graywacke & $\begin{array}{l}\text { Graywacke, granite, } \\
\text { argillite, green- } \\
\text { stone, dike, and } \\
\text { breccla } \\
-2 \% \text { quartz }\end{array}$ & $\begin{array}{l}-0.5 \% \text { magnetite, } 1 \text { ittle } \\
\text { pyrite }\end{array}$ \\
\hline 78 & $5 F 78$ & 8 & 25 & 10 & 50 & 2 & 35 & 0 & Blank & Covered & $\begin{array}{l}\text { Argilite, granite, } \\
\text { graywacke, sand- } \\
\text { stone, } \& \text { dike }\end{array}$ & $\begin{array}{l}-17 \text { magnetite, } 20 \mathrm{gr} \\
\text { zircon, little pyrite }\end{array}$ \\
\hline 79 & $5 E 77$ & 8 & 30 & 15 & 90 & 3 & 25 & 9 & Blank & Covered & $\begin{array}{l}\text { Argilifte, gray- } \\
\text { wacke, slate, sand- } \\
\text { stone, granite, } \\
\text { greenstone, \& } \\
\text { porphyry } \\
-2 \% \text { quartz }\end{array}$ & $\begin{array}{l}-1 \% \text { magnetite, little } \\
\text { pyrite, }+20 \text { gr zircon }\end{array}$ \\
\hline 80 & $5 \times 73$ & 8 & 20 & 10 & 60 & 3 & 35 & 2 & Purple & Covered & $\begin{array}{l}\text { Axg111ite, gray- } \\
\text { wacke, sandstone, } \\
\text { siate, }-2 \% \text { quartz }\end{array}$ & $\begin{array}{l}\text {-1\% magnetite, little } \\
\text { pyrite, }+20 \text { gr zircon }\end{array}$ \\
\hline 81 & $5 E 74$ & 8 & 20 & 10 & 55 & 3 & 30 & 1 & Purple & Covered & $\begin{array}{l}\text { Argillite, slate, } \\
\text { greenstone, granite } \\
-2 \% \text { quartz }\end{array}$ & $\begin{array}{l}-1 \% \text { megnetite, } 1 \text { ittle. } \\
\text { pyrite, t20 gr zircon, } \\
3 \text { gr scheelite }\end{array}$ \\
\hline 82 & $5 \times 75$ & 8 & 25 & 10 & 50 & 2 & 30 & 1 & Red & Covered & $\begin{array}{l}\text { Graywacke, granite, } \\
\text { argl1lite, slate, } \\
\text { greenstone, dike } \& \\
\text { porphyry } \\
\text {-2\% quertz }\end{array}$ & $\begin{array}{l}-1 \% \text { magnet1te, little } \\
\text { pyrite, } \pm 20 \text { gr zircon }\end{array}$ \\
\hline 83 & 5576 & 8 & 35 & 10 & 60 & 3 & 45 & 1 & Purple & Covered & $\begin{array}{l}\text { Graywacke, granite, } \\
\text { argillite, slate } \\
\text { greenstone, } \\
\text { argillite breccia } \\
\text { - } 2 \% \text { quartz }\end{array}$ & $\begin{array}{l}\text {-17 magnetite, lfttle } \\
\text { pyrite, }+20 \text { gr zircon }\end{array}$ \\
\hline
\end{tabular}




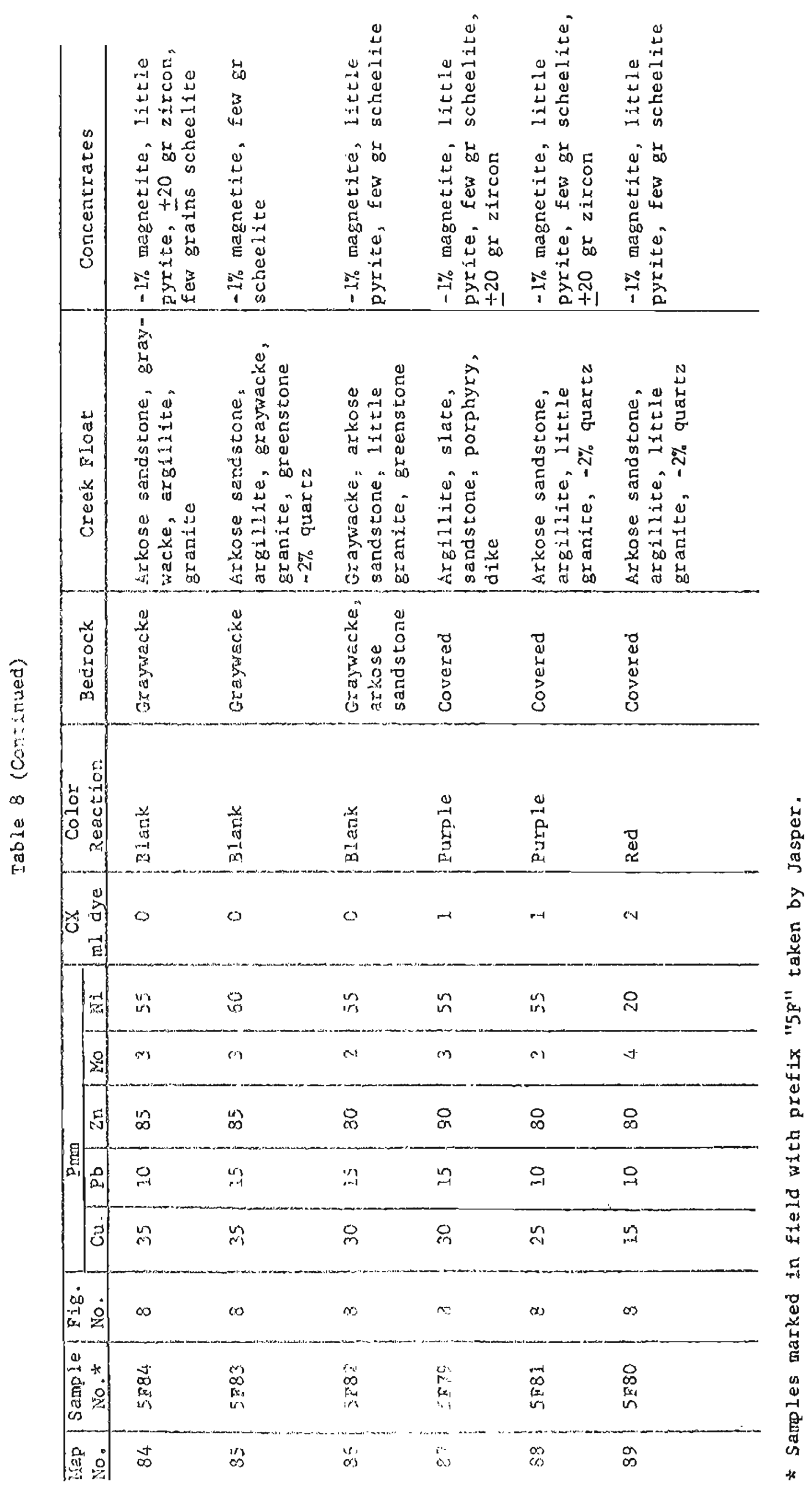




\begin{tabular}{|c|c|c|c|c|c|c|c|c|c|}
\hline 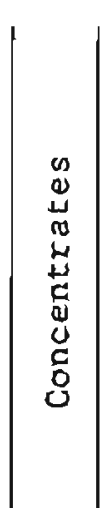 & 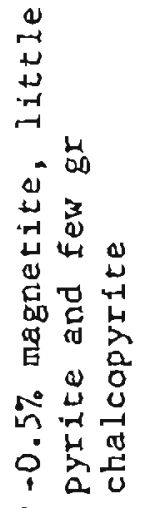 & 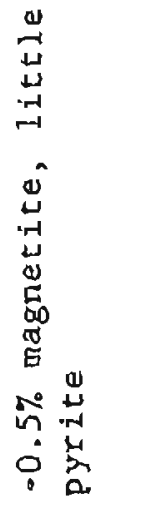 & 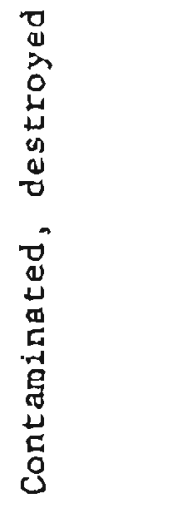 & 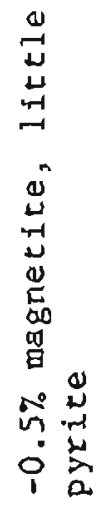 & 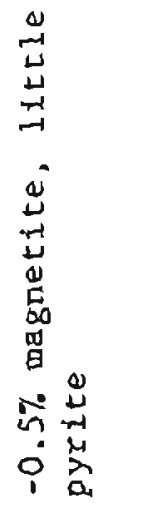 & 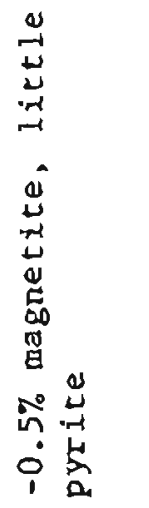 & 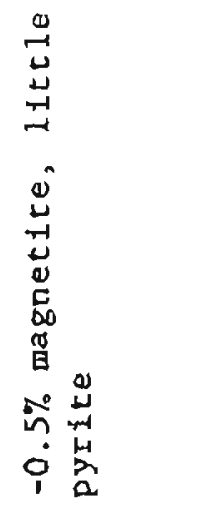 & 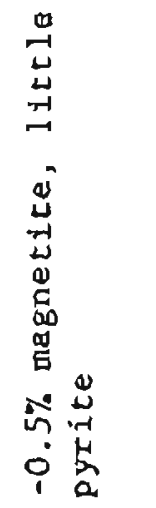 & 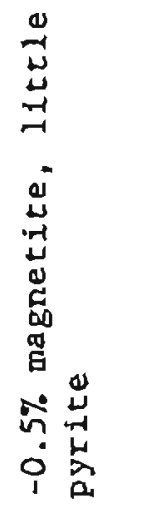 \\
\hline 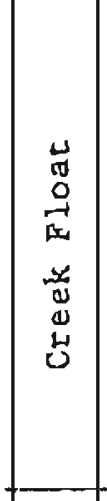 & 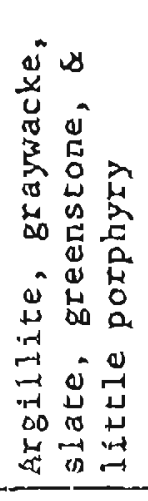 & 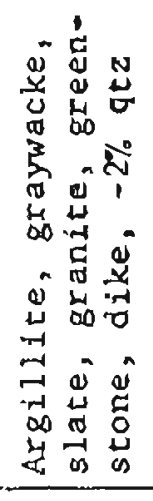 & 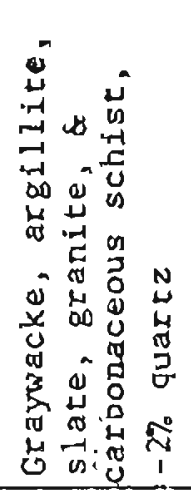 & 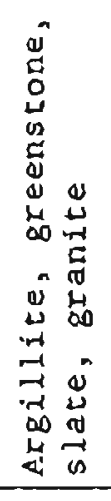 & 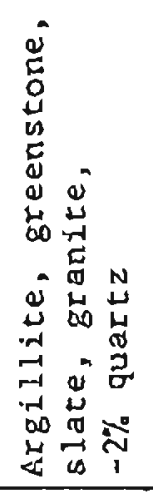 & 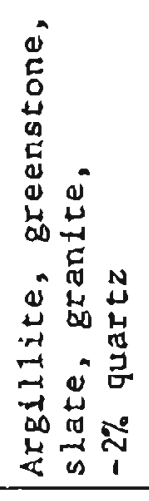 & 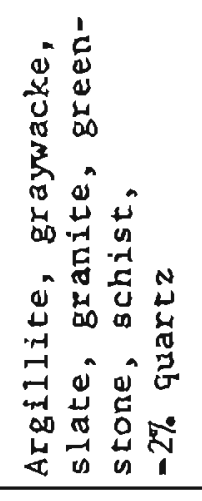 & 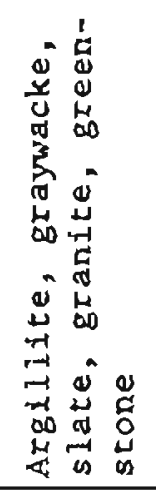 & 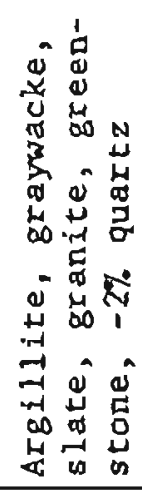 \\
\hline 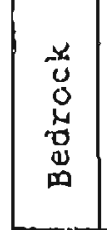 & 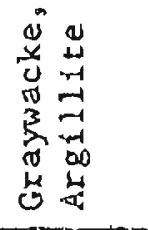 & 菋 & 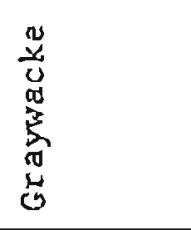 & 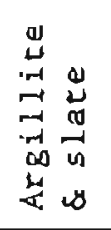 & $\begin{array}{l}0 \\
0 \\
4 \\
01 \\
3 \\
0 \\
0\end{array}$ & 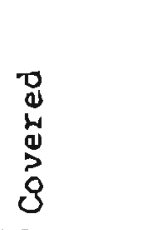 & \begin{tabular}{l}
0 \\
\multirow{2}{*}{} \\
0 \\
0 \\
0 \\
0
\end{tabular} & 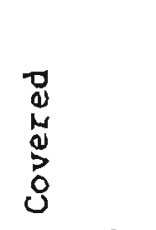 & 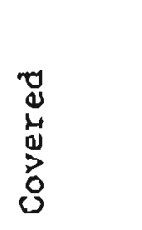 \\
\hline 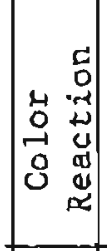 & $\begin{array}{l}0 \\
0 \\
0 \\
a \\
a \\
a\end{array}$ & 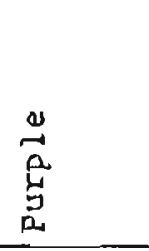 & 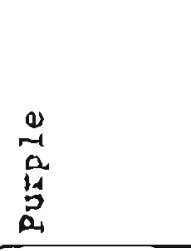 & $\stackrel{a}{\stackrel{a}{a}}$ & $\begin{array}{l}\stackrel{0}{a} \\
\overrightarrow{0} \\
\stackrel{5}{5} \\
0\end{array}$ & 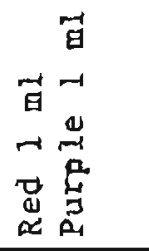 & 离 & 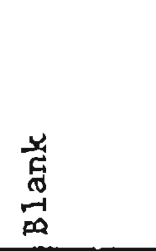 & 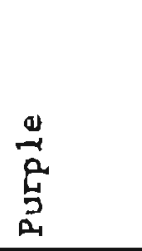 \\
\hline 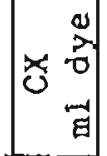 & $\rightarrow$ & $r$ & $\underset{\sim}{n}$ & $r-1$ & $\neg$ & $C v$ & $\neg$ & 0 & $m$ \\
\hline$z$ & $R$ & $\stackrel{n}{n}$ & $\stackrel{m}{N}$ & $\stackrel{7}{7}$ & 出 & $\tilde{m}$ & 웅 & n & $\stackrel{n}{n}$ \\
\hline 을 & $m$ & 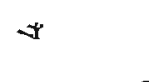 & $\exists$ & $m$ & $N$ & $m$ & $\checkmark$ & $\checkmark$ & $m$ \\
\hline 兵 & $\stackrel{\infty}{\infty}$ & $\stackrel{n}{\approx}$ & $\underset{8}{8}$ & 용 & S & $\infty$ & $\approx$ & $\infty$ & $\underset{\sim}{\sim}$ \\
\hline 㤩品路 & $\cong$ & 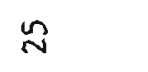 & 오 & $\mathscr{n}$ & 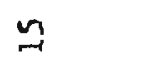 & 요 & 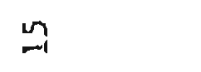 & 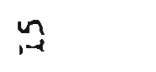 & i \\
\hline 3 & g & 이 & 잉|이 & $\vec{v}$ & $\ddot{m}$ & 요 & $\stackrel{\text { ㄱ }}{ }$ & 요 & in \\
\hline 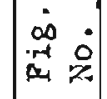 & $a$ & $\sigma$ & $a$ & or & a & $\Omega$ & $\sigma$ & $a$ & $a$ \\
\hline 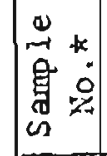 & $\begin{array}{l}0 \\
\text { in } \\
\text { in }\end{array}$ & $\begin{array}{l}0 \\
\text { 是 } \\
\text { 品 }\end{array}$ & $\begin{array}{l}\infty \\
\infty \\
0 \\
\mathfrak{L}_{2} \\
n\end{array}$ & $\overrightarrow{0}$ & 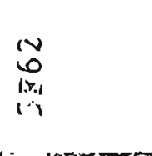 & $\begin{array}{l}m \\
0 \\
\text { \& } \\
\text { in }\end{array}$ & 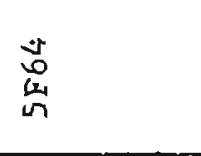 & $\begin{array}{l}n \\
0 \\
\text { su } \\
\text { n }\end{array}$ & $\begin{array}{l}\text { ô } \\
\text { 绐 }\end{array}$ \\
\hline $\mid \begin{array}{ll}0 \\
0 \\
0\end{array}$ & 응 & $\vec{\sigma}$ & $\widetilde{\sigma}$ & $c y$ & $\therefore$ & un & o & $\hat{a}$ & $\begin{array}{l}\infty \\
\sigma\end{array}$ \\
\hline
\end{tabular}


Table 9 (Continued)

\begin{tabular}{|c|c|c|c|c|c|c|c|c|c|c|c|c|}
\hline \multirow{2}{*}{$\begin{array}{l}\text { Map } \\
\text { No. }\end{array}$} & \multirow{2}{*}{$\begin{array}{c}\text { Samp le } \\
\text { No.* }\end{array}$} & \multirow{2}{*}{$\begin{array}{l}\text { Fig. } \\
\text { No. }\end{array}$} & \multicolumn{5}{|c|}{ Pant } & \multirow{2}{*}{$\begin{array}{c}\mathrm{cX} \\
\mathrm{m} 1 \mathrm{dye}\end{array}$} & \multirow{2}{*}{$\begin{array}{l}\text { Color } \\
\text { React 1on }\end{array}$} & \multirow{2}{*}{ Bedrock } & \multirow{2}{*}{ Creek Float } & \multirow{2}{*}{ Concentrates } \\
\hline & & & $\mathrm{Cu}$ & $\underline{\mathrm{Pb}}$ & $\mathrm{Zn}$ & Mo & $\mathrm{Ni}$ & & & & & \\
\hline 99 & $5 \mathrm{~F} 70$ & 9 & 25 & 10 & 80 & 4 & 45 & 0 & B lank & Covered & $\begin{array}{l}\text { Argillite, graywacke, } \\
\text { slate, granite, green- } \\
\text { stone, }=27 \text { quartz }\end{array}$ & $\begin{array}{l}-0.5 \% \text { magnetite, little } \\
\text { pyrite }\end{array}$ \\
\hline 100 & $5 \times 71$ & 9 & 20 & 15 & 105 & 3 & 55 & 0 & B lank & Covered & $\begin{array}{l}\text { Graywacke, argl11ite, } \\
\text { granite }\end{array}$ & none noted \\
\hline 101 & $5 F 72$ & 9 & 40 & 15 & 105 & 3 & 55 & 1 & Purple & Covered & $\begin{array}{l}\text { Graywacke, argilitee, } \\
\text { granite }\end{array}$ & $\begin{array}{l}-0.5 \% \text { magnetite, little } \\
\text { pyrite, +20 gr scheelite, } \\
\text { t20 gr zircon }\end{array}$ \\
\hline
\end{tabular}

* Samples marked in fleld with prefix "SF" taken by Jasper. 


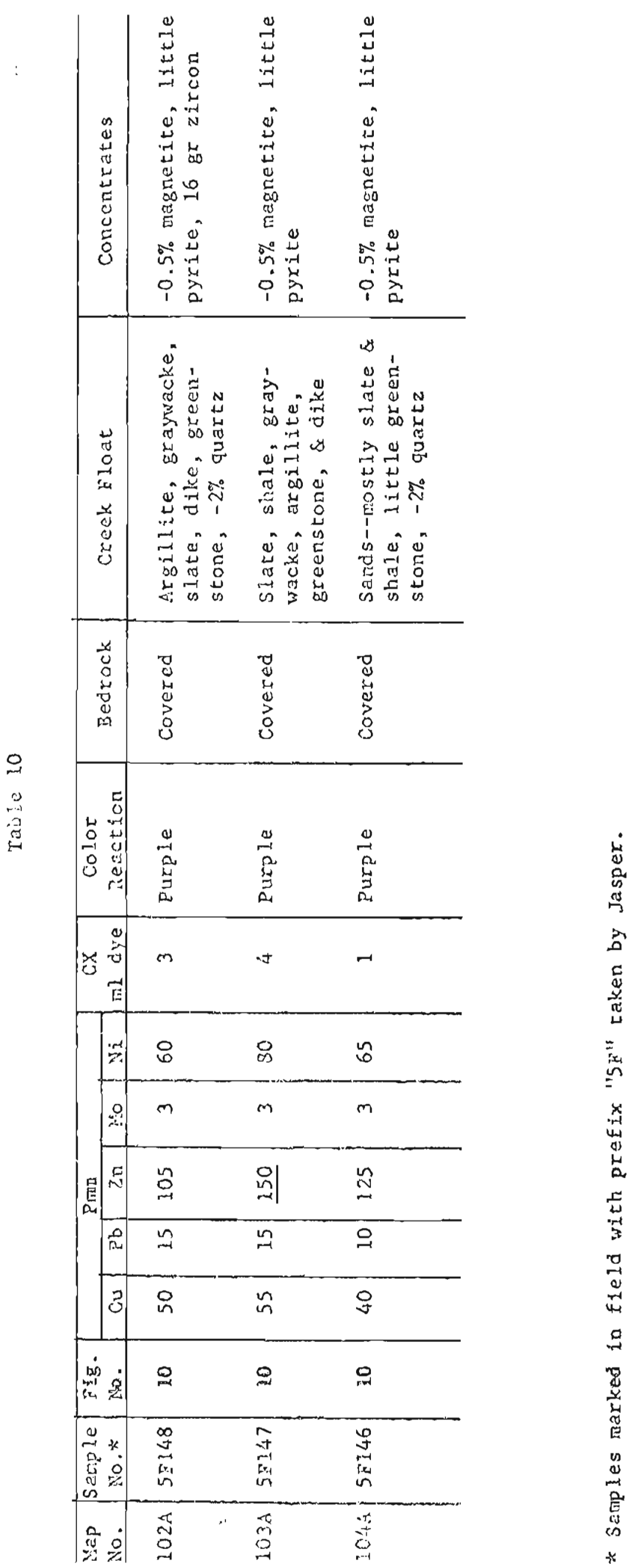


㲾

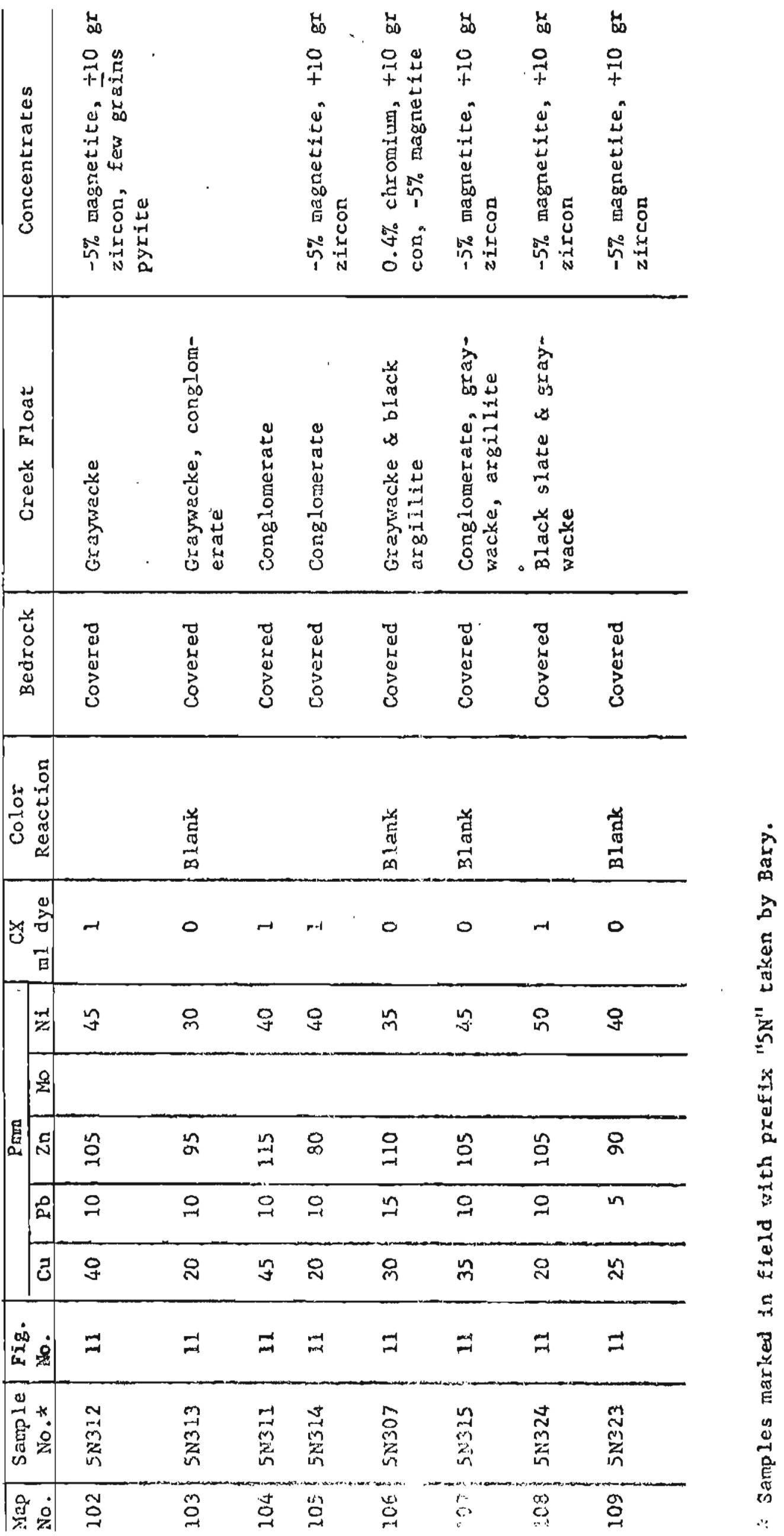




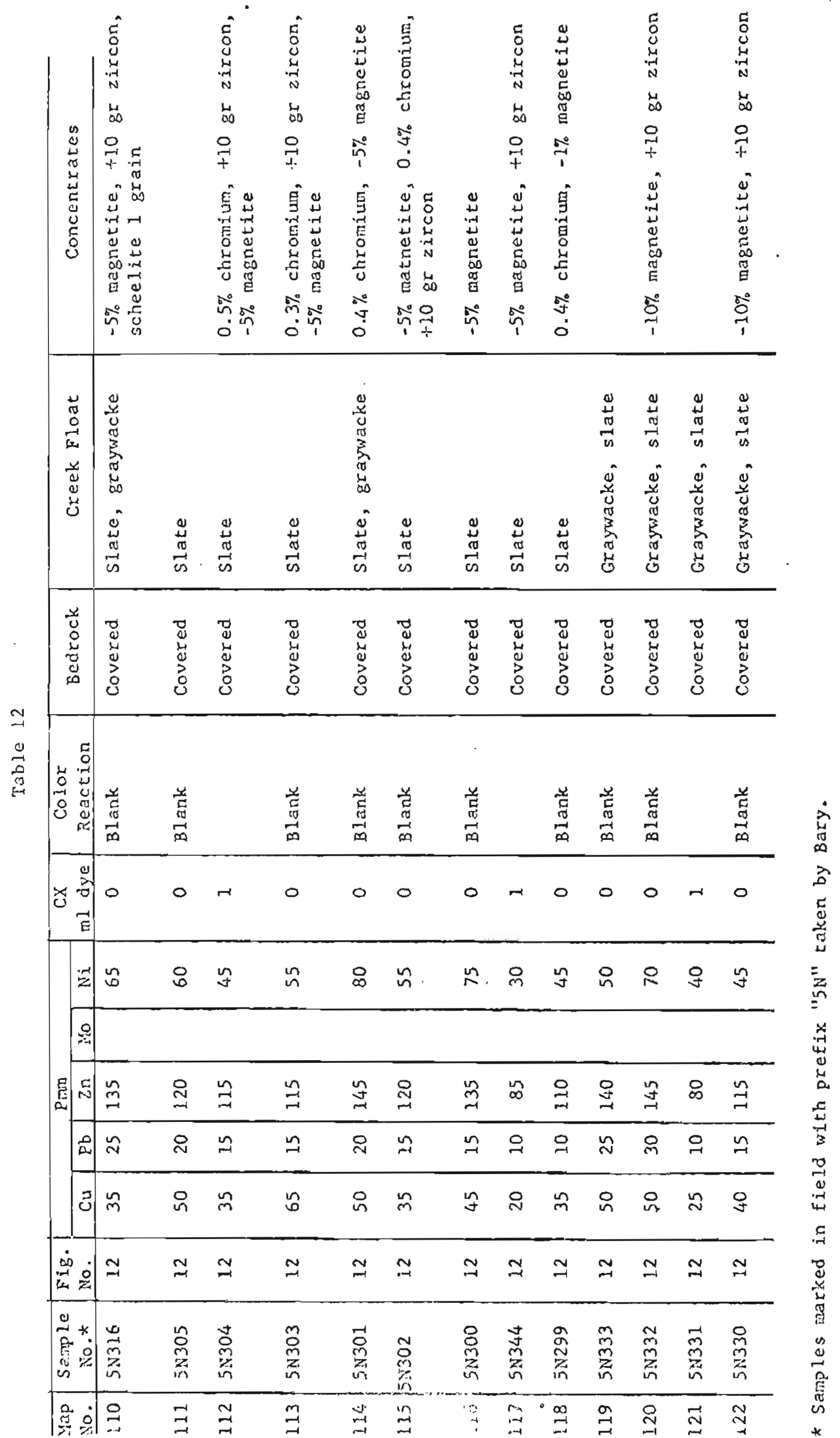




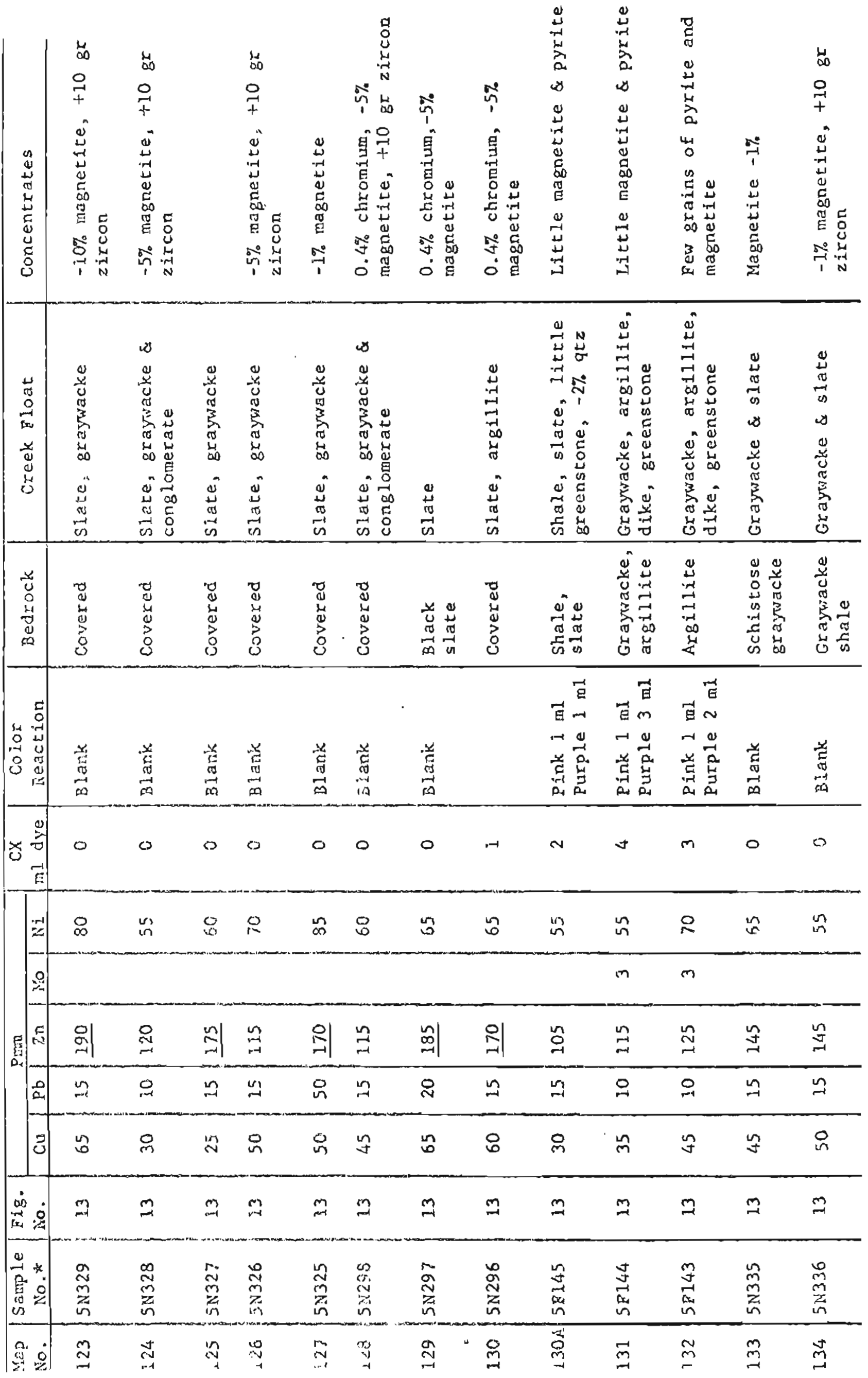




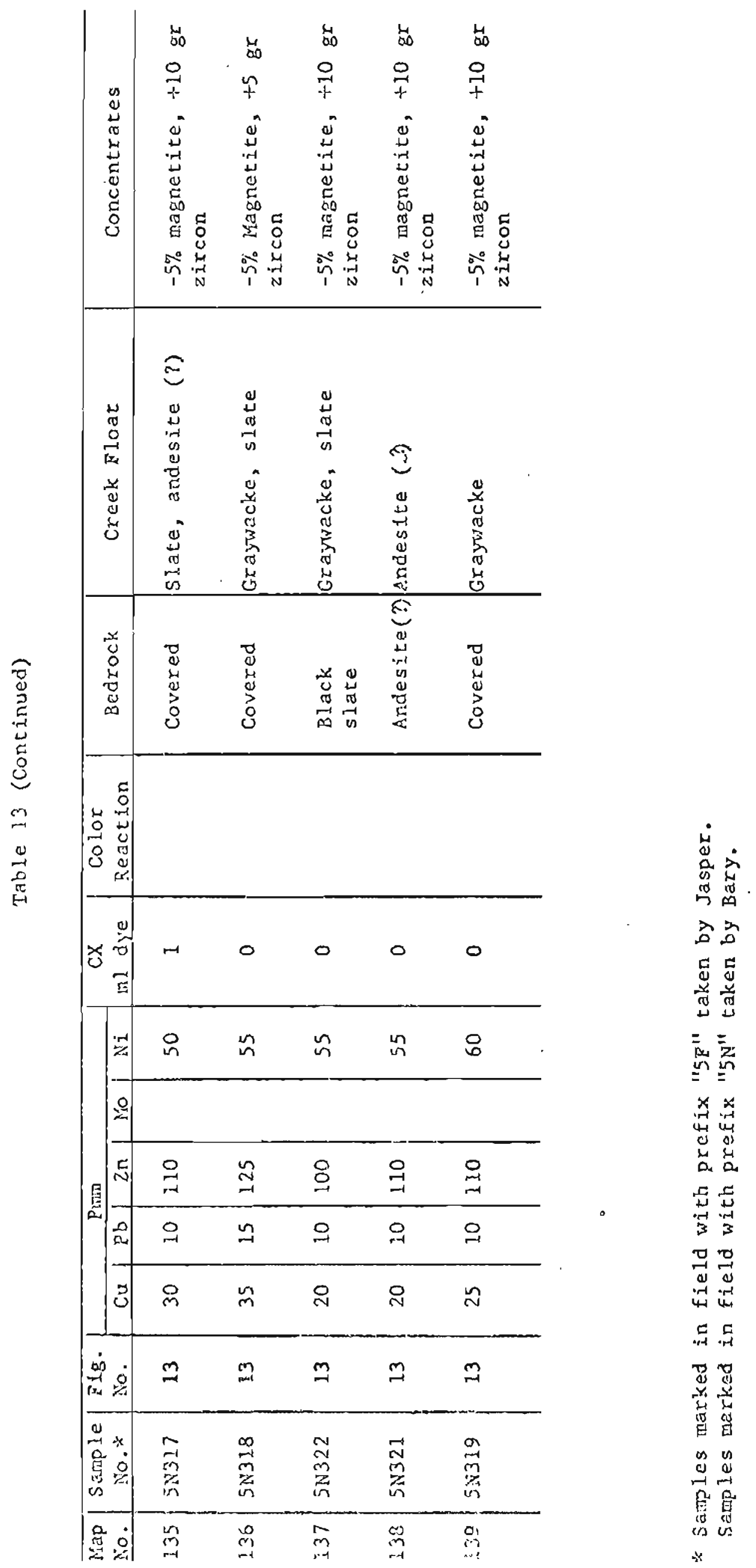




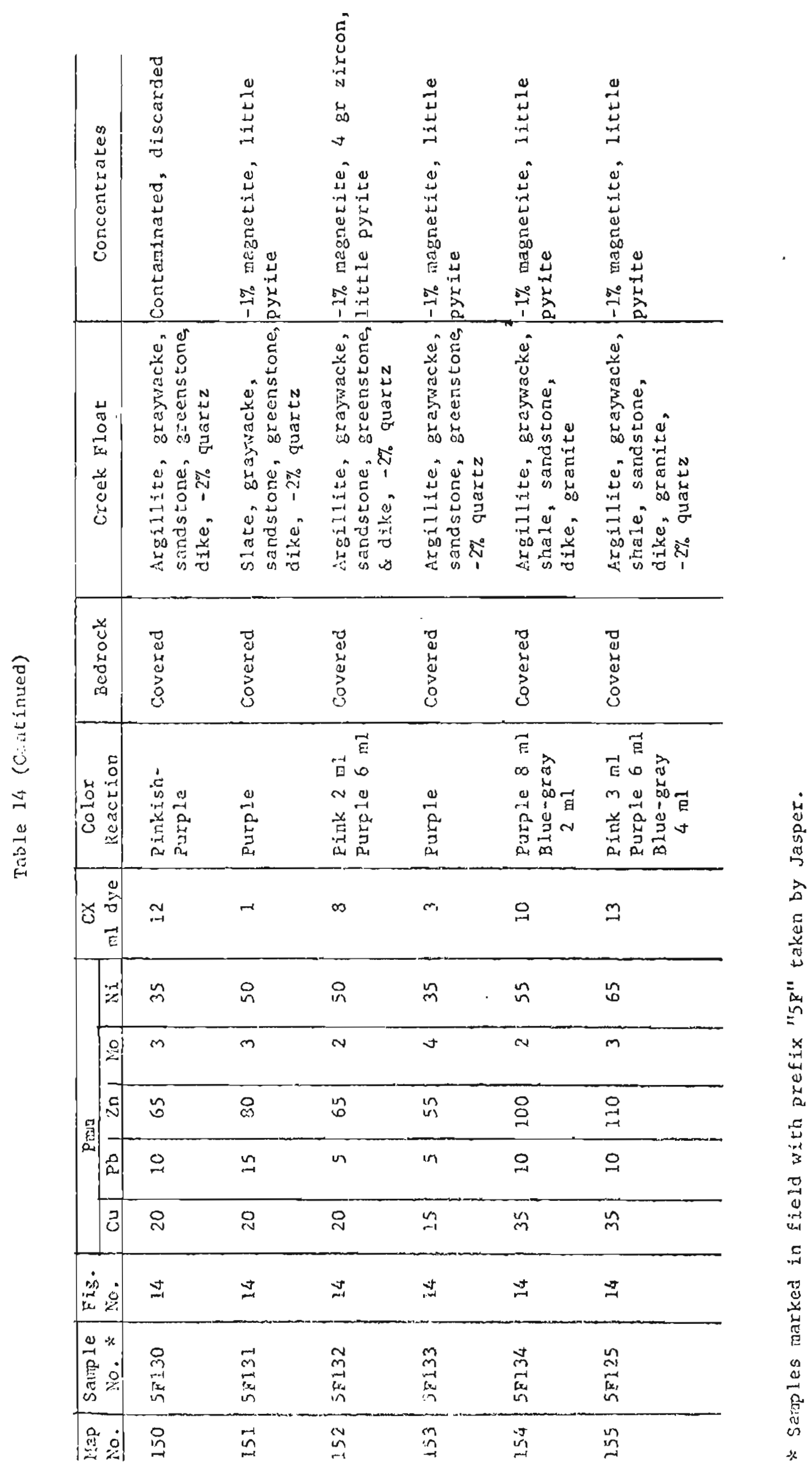




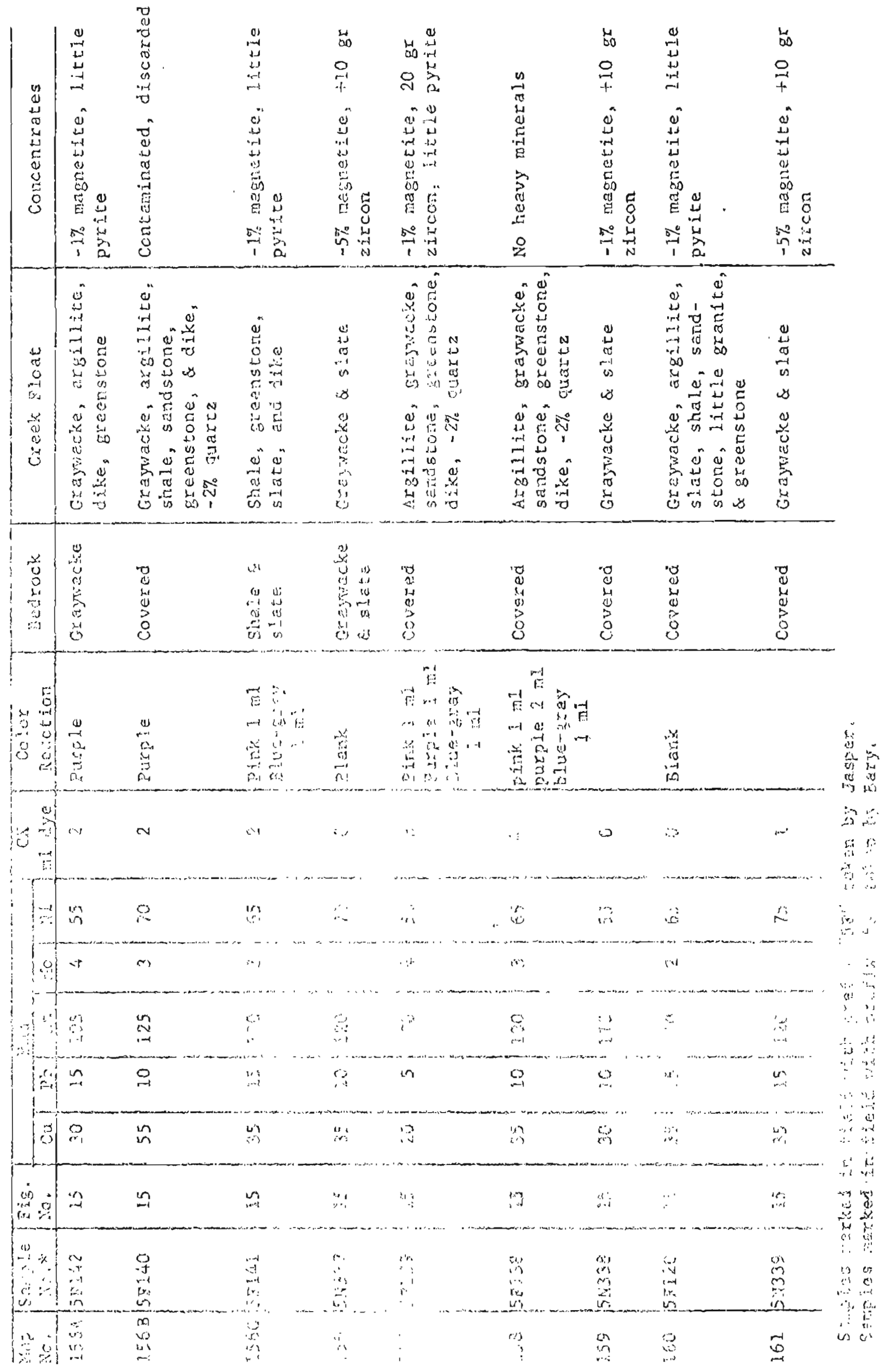




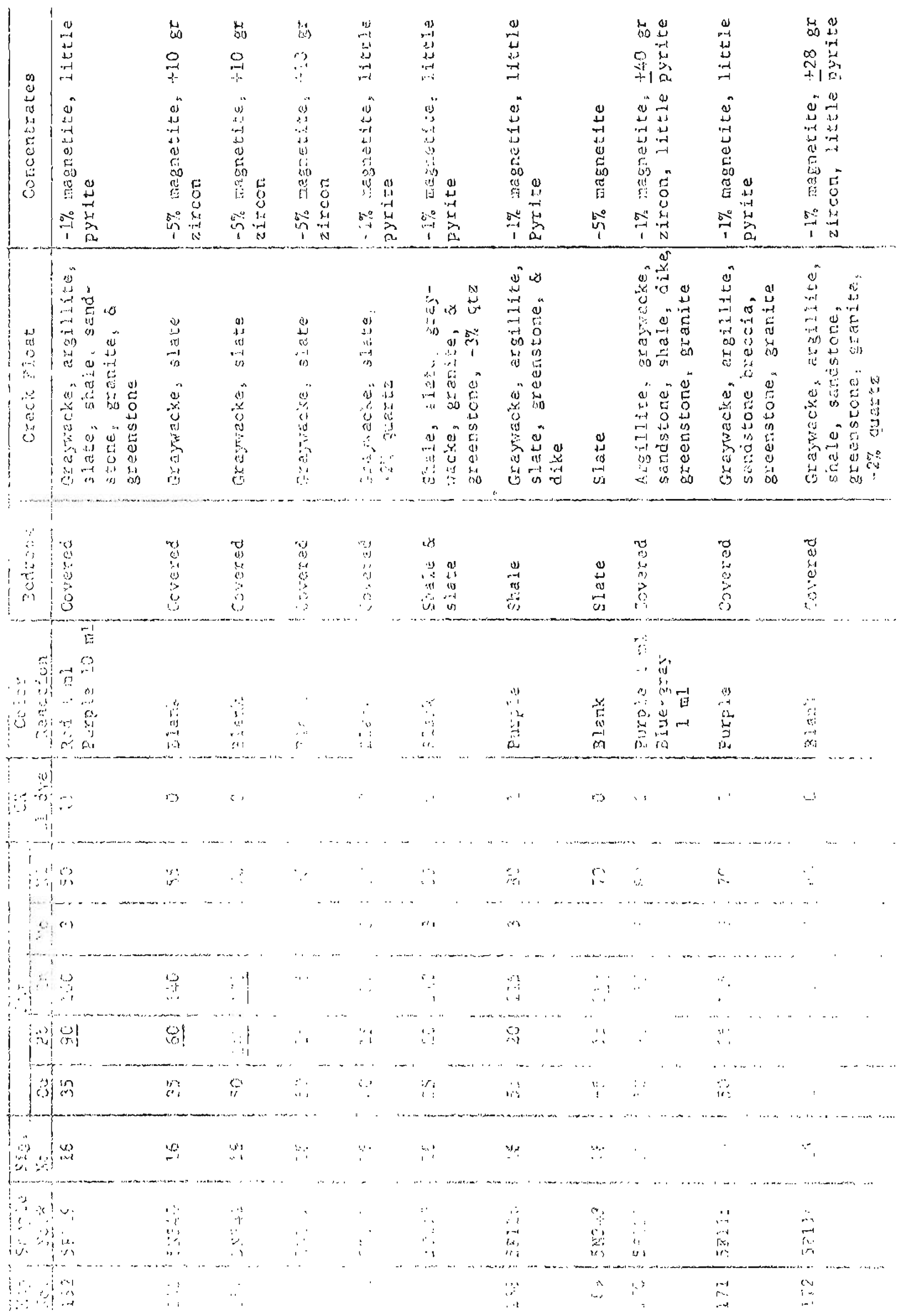




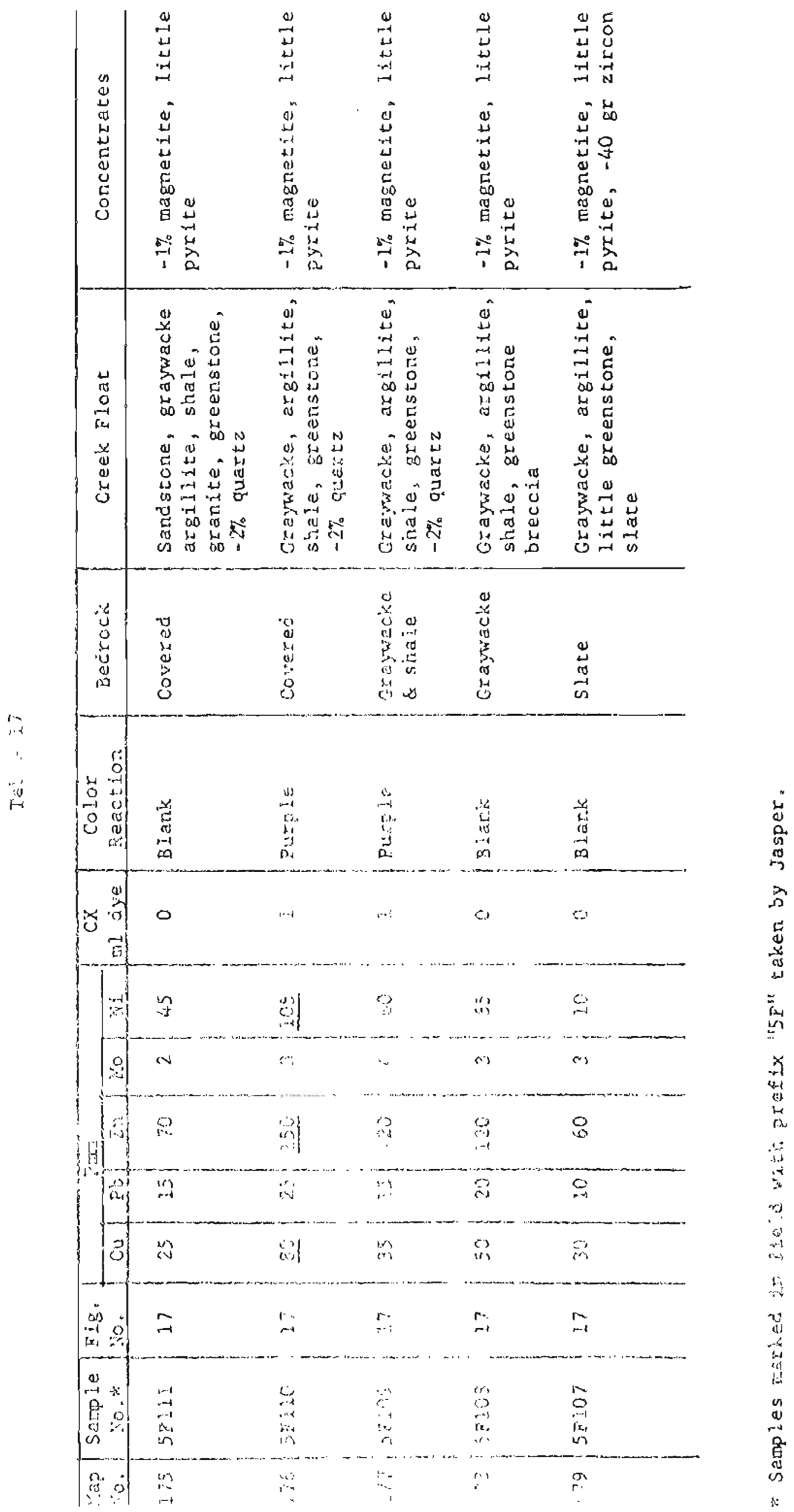


TaE-= 18

\begin{tabular}{|c|c|c|c|c|c|c|c|c|c|c|c|c|}
\hline \multirow{2}{*}{$\begin{array}{l}\text { REO } \\
\therefore 0\end{array}$} & \multirow{2}{*}{$\begin{array}{c}\text { Sampie } \\
\text { No.* }\end{array}$} & \multirow{2}{*}{$\begin{array}{l}\text { Fig. } \\
\text { No. }\end{array}$} & \multicolumn{5}{|c|}{$M$} & \multirow{2}{*}{$\begin{array}{c}c x \\
\text { m dye }\end{array}$} & \multirow{2}{*}{$\begin{array}{c}\text { Color } \\
\text { Refetion }\end{array}$} & \multirow{2}{*}{ Bedrock } & \multirow{2}{*}{ Creek Ploat } & \multirow{2}{*}{ Concentrates } \\
\hline & & & $\mathrm{C:2}$ & $\mathrm{Pb}$ & $\mathrm{Zn}$ & $\%$ & 81 & & & & & \\
\hline 180 & $5 F 106$ & is & 20 & 15 & 115 & 2 & 60 & 0 & Blank & Slate & $\begin{array}{l}\text { Slate, graywacke, } \\
\text { argilitte, little } \\
\text { greenstone, - } 27 \text { qtz }\end{array}$ & $\begin{array}{l}-1 \% \text { magnetite, little } \\
\text { pyrite }\end{array}$ \\
\hline 183 & $5 F 195$ & 18 & 20 & 5 & 50 & 2 & 30 & 0 & Blank & Covered & $\begin{array}{l}\text { Graywacke, argilitte, } \\
\text { slate, Iittle green- } \\
\text { stone }\end{array}$ & $\begin{array}{l}-1 \% \text { magnetite, litcle } \\
\text { pyrite }\end{array}$ \\
\hline 28 & 5104 & 28 & 20 & 5 & 65 & 3 & 40 & 1 & Eurple & Covered & $\begin{array}{l}\text { Graywacke, argillite, } \\
\text { shale }\end{array}$ & $\begin{array}{l}-1 \% \text { wagnetite, }+32 \mathrm{gr} \\
\text { zircon, little pyrite }\end{array}$ \\
\hline 183 & $5 F 103$ & 18 & 65 & 20 & 130 & 3 & 85 & 0 & Blank & Shale & $\begin{array}{l}\text { Graphitfc shale, gray- } \\
\text { wacke, argillite }\end{array}$ & $\begin{array}{l}\text { - } 1 \% \text { magnetite, } 1 \text { ittle } \\
\text { Pyrite }\end{array}$ \\
\hline 163 & $5 F \div 2$ & 15 & 35 & 15 & 225 & 2 & 75 & $i$ & Purple & Covered & $\begin{array}{l}\text { Graptitic shale, gray } \\
\text { wacke, argilite, } \\
\text { little greenstone }\end{array}$ & $\begin{array}{l}-1 \% \text { magnetite, little } \\
\text { pyrite }\end{array}$ \\
\hline 84 & 35100 & 18 & 20 & 10 & 90 & 4 & 40 & $\mathrm{C}$ & Biank & Siate & $\begin{array}{l}\text { Arkose sandstone, } \\
\text { slate, graywacke, } \\
\text { little greenstone, } \\
-2 \% \text { quartz }\end{array}$ & $\begin{array}{l}-1 \% \text { magnetite, } 1 \text { ittle } \\
\text { Pyr ite }\end{array}$ \\
\hline$\$ 85$ & $5810:$ & 15 & 45 & 15 & 90 & 3 & 40 & 2 & Purple & Covered & $\begin{array}{l}\text { Arkose sandstore, } \\
\text { little greenstone, } \\
\text { graywake, slate, } \\
-2 \% \text { quartz }\end{array}$ & $\begin{array}{l}\text { - } 17 \text { ragnetite, littie } \\
\text { pyrite, } 14 \text { gr zircon }\end{array}$ \\
\hline 186 & $5 \mathrm{~F} 92$ & 18 & 50 & $: 0$ & 25 & 3 & 70 & 0 & B lank & Covered & $\begin{array}{l}\text { Graywacke, argillite, } \\
\text { slate, arkose sand- } \\
\text { stone, little granite, } \\
\text { greenstone }\end{array}$ & $\begin{array}{l}\text { Few grains magnetite } \\
\text { Pyrite, } 3 \text { gr zircon }\end{array}$ \\
\hline
\end{tabular}

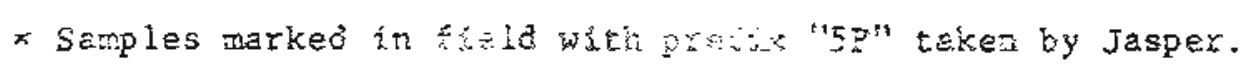




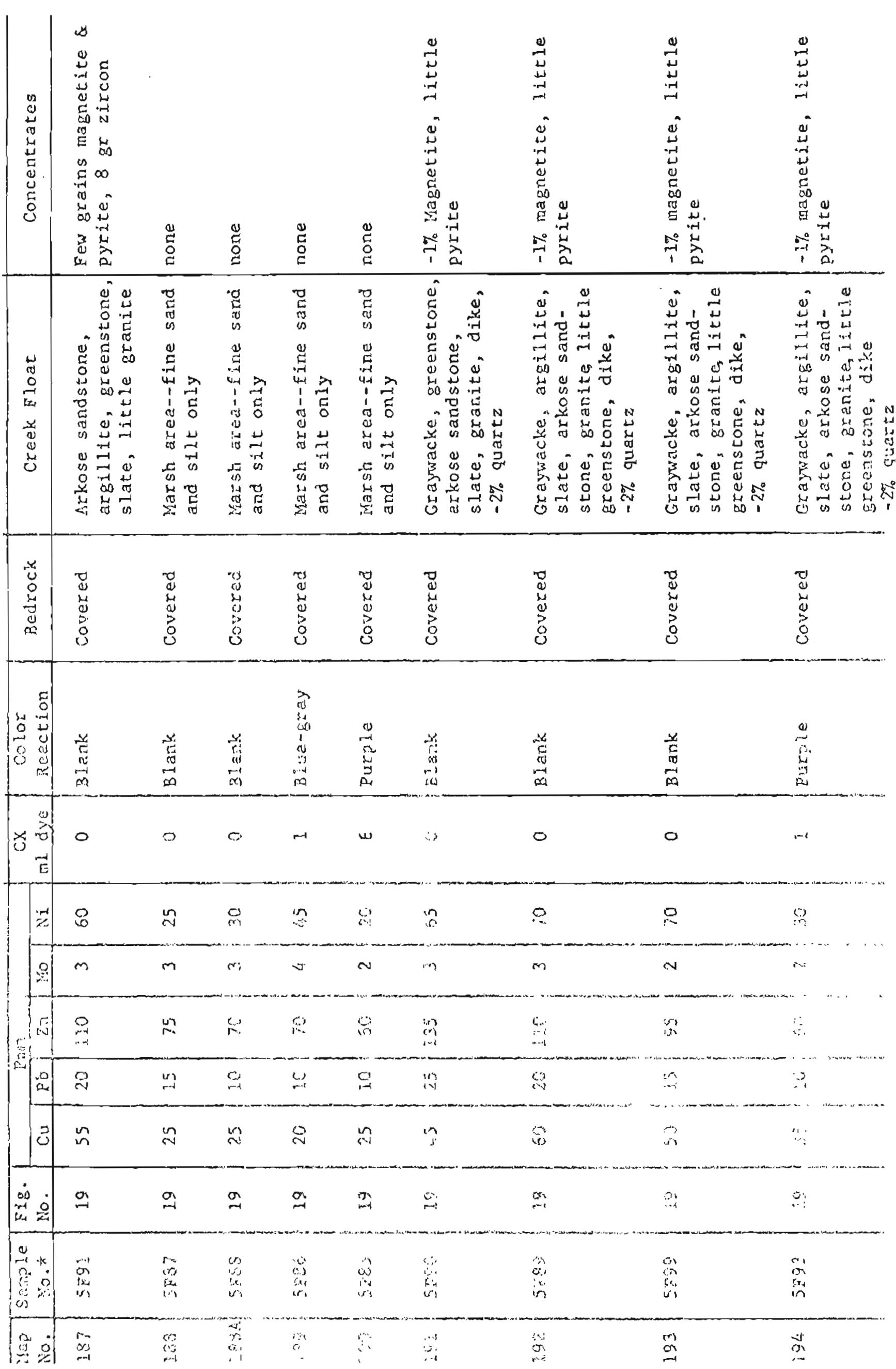


